Protein digestion kinetics in pigs and poultry

Hsuan Chen 


\section{Thesis committee}

\section{Promotor}

Prof. Dr W. H. Hendriks

Professor of Animal Nutrition

Wageningen University \& Research

\section{Co-promotors}

Dr A. J. M. Jansman

Senior researcher, Animal Nutrition

Wageningen University \& Research

Dr P. A. Wierenga

Assistant Professor, Laboratory of Food Chemistry

Wageningen University \& Research

\section{Other members}

Prof. Dr M. A. J. S. van Boekel, Wageningen University \& Research

Prof. Dr J. E. Lindberg, Swedish University of Agricultural Sciences, Uppsala, Sweden

Dr M. R. Mensink, Wageningen University \& Research

Dr A. Narcy, INRA, Tours, France

This research was conducted under the auspices of the Graduate School of Wageningen Institute of Animal Sciences (WIAS). 


\section{Protein digestion kinetics in pigs and poultry}

\section{Hsuan Chen}

\section{Thesis}

submitted in fulfilment of the requirements for the degree of doctor at Wageningen University by the authority of the Rector Magnificus

Prof. Dr. A.P.J. Mol, in the presence of the

Thesis Committee appointed by the Academic Board to be defended in public on Wednesday 22 November 2017 at 4 p.m. in the Aula 
Hsuan Chen

Protein digestion kinetics in pigs and poultry 168 pages.

PhD thesis, Wageningen University, Wageningen, the Netherlands (2017) With references, with summary in English

ISBN 978-94-6343-797-4

DOI http://dx.doi.org/10.18174/423753 




\section{Table of contents}

$\begin{array}{lll}\text { Chapter } 1 & \text { General introduction } & 9\end{array}$

Chapter 2 In vitro protein digestion kinetics of protein sources for pigs

Chapter $3 \quad$ Protein sources differ in digestion kinetics in the small intestine of growing pigs and affect postprandial appearance of amino acids in blood

Chapter $4 \quad$ Protein digestion kinetics in the small intestine of broilers differs among protein sources

Chapter $5 \quad$ Effect of synchronising the kinetics of protein and starch digestion in the small intestine on the growth performance and carcass characteristics in broilers

Chapter 6 General discussion

List of abbreviations

Summary

Acknowledgments

About the author

Curriculum vitae

List of publication

Training and supervision plan 

Chapter 1

General introduction 


\section{Importance of sustainable feeding of pigs and poultry}

The global human population is expected to increase to 9.1 billion by 2050 and to 11.2 billion by 2100 (UN, 2015). To feed the rapid growing global population, 70 to $100 \%$ more food is required compared to the current production to provide global food security (Godfray et al., 2010). By 2050, meat production is expected to increase to 455 billion kg, of which pig and poultry meat accounts for approximately 31 and $40 \%$, respectively (Steinfeld et al., 2006). To meet this increasing worldwide demand for animal meat, more feed ingredients, in absolute quantity, are needed to pig and poultry feed manufacturers. The competition between human food and animal feed ingredient cultivation on the limited arable land, however, will likely result in a shortage of animal feed ingredients in the future (FAO, 2009). To overcome the challenge of a global shortage and increasing prices of current protein sources, a multi-targeted approach is needed. Increasing the utilization efficiency of current protein sources as well as development of alternative protein sources are considered as main strategies for sustainable feeding of pigs and poultry in the future. Insects, for example, are potential alternative protein sources which can be used in pig and poultry diets (Veldkamp et al., 2012). They not only contribute to the protein fraction in the diet but also are a good source of fat, minerals and vitamins. In addition to insects, seaweeds, algae and yeast are also considered potential alternative protein sources. To increase the utilization efficiency of protein sources, it is necessary to further elucidate the factors limiting protein digestion as well as factors influencing the post-absorption utilization of dietary protein in monogastric farm animals.

\section{Digestion of dietary protein in pigs and poultry}

In the gastrointestinal tract (GIT) of pigs and poultry, dietary protein requires to be broken down into di- and tri-peptides or free amino acids (AAs) prior to absorption by enterocytes in the small intestinal mucosa (Webb et al., 1992; Ganapathy et al., 2000). In pigs, digestion of dietary protein starts in the stomach by the action of pepsin and hydrochloric acid. In poultry, digestion of dietary protein can already take place in the crop by microbial fermentation (Rehman et al., 2007), followed by the hydrolysis by pepsin and hydrochloric acid in the proventriculus and gizzard. Hydrolysis of protein by pepsin is affected by the AA residue at the amino group end of peptide bonds. In general, pepsin rarely cleaves the carboxyl end of histidine and lysine (Hamuro et al., 2008). After gastric digestion, dietary protein is further digested by pancreatic proteases 
in the small intestine (i.e. trypsin, chymotrypsin, elastase, and carboxypeptidase $A$ and B). Trypsin and chymotrypsin are endopeptidases, Trypsin cleaves the carboxyl end of arginine and lysine, and chymotrypsin cleaves the carboxyl end of phenylalanine, tyrosine, tryptophan, valine and leucine (Riviere and Tempst, 2001). Elastase and carboxypeptidase $A$ and $B$ are exopeptidases, which release AAs from the carboxyl terminal side of peptides. Elastase releases alanine, glycine and serine, and carboxypeptidase $A$ and $B$ releases aromatic $A A s$ and basic $A A s$, respectively (Folk et al., 1960; Riviere and Tempst, 2001). The final stage of dietary protein digestion occurs at the brush border membrane of the small intestinal mucosa, which involves several peptidases including endopeptidases, carboxypeptidases, and aminopeptidases (Erickson and Kim, 1990).

Dietary protein can also be fermented by the commensal microbiota in the GIT. Proteolytic fermentation predominantly occurs in the colon of pigs and the caeca of poultry. Proteolytic fermentation not only produces volatile fatty acids (VFAs), which can be used as an energy source by animals, but also potentially toxic metabolites such as ammonia, amines, volatile phenols and indoles, which have a negative impact on gut health and animal performance (Williams et al., 2001). For example, ammonia produced by proteolytic fermentation can disturb the development of the intestinal mucosa and reduce villus height (Visek, 1984; Nousiainen, 1991).

Ileal and faecal protein digestibility differ substantially among commonly used feed ingredients in pigs and poultry diets (Table 1.1). The extent of protein digestion can be affected by the intrinsic characteristics of proteins present in protein sources. The number and accessibility of cleavage sites for proteases largely depend on the $A A$ sequence of polypeptide chains (chemical composition) and their conformation, which is determined by the AA sequence. For instance, rapeseed albumins (napin) showed a higher resistance to pepsin hydrolysis in vitro compared to rapeseed globulins (cruciferin) (Malabat and Rabiller, 2001). This is likely due to the compact conformation of napins due to the presence of disulphide bonds (Schwenke et al., 1988). Moreover, in vitro protein digestibility was negatively correlated to the proportion of intramolecular $\beta$-sheet structures but positively correlated to the ratio between $\alpha$-helix and $\beta$-sheet structures in plant protein sources (Carbonaro et al., 2012; Rubio et al., 2014). With respect to physicochemical properties, a water-soluble form of casein (i.e. $\mathrm{Na}^{+}$-caseinate) was digested approximately 2-fold faster in vitro than waterinsoluble casein at pH 8.0 (Tonheim et al., 2007). The extent of digestion, however, did 
not differ for both soluble and insoluble caseins. In rapeseed meal, the soluble protein fraction showed a faster hydrolysis rate but a lower extent of hydrolysis than the insoluble protein fraction (Salazar-Villanea et al., 2017). The non-protein constituents can also interact with the proteins in the protein source and, therefore, affect protein digestion. For instance, tannins present in legume seeds and phytate present in soybeans and other protein sources of plant origin can bind to proteins. The bound proteins are not susceptible to enzymatic hydrolysis by digestive enzymes, leading to a reduced protein digestibility in pigs (Mangan, 1988; Selle et al., 2012).

Table 1.1. Protein content and protein digestibility of commonly used feed ingredients in pig and broiler diets.

\begin{tabular}{|c|c|c|c|c|c|}
\hline \multirow{3}{*}{ Feed ingredient } & \multirow{3}{*}{$\begin{array}{l}\text { Protein content } \\
\qquad(\mathrm{g} / \mathrm{kg})\end{array}$} & \multicolumn{4}{|c|}{ Digestibility (\%) $^{1}$} \\
\hline & & \multicolumn{2}{|c|}{ Pig } & \multicolumn{2}{|c|}{ Broiler } \\
\hline & & SID & AID & SID & ATTD \\
\hline \multicolumn{6}{|l|}{ Cereal grains } \\
\hline Maize & $64-88$ & 82 & 69 & 90 & 83 \\
\hline Wheat & $85-139$ & 89 & 80 & 88 & 81 \\
\hline Barley & $76-124$ & 80 & 70 & 90 & 70 \\
\hline Rice & $69-87$ & 95 & 82 & - & 82 \\
\hline Sorghum & $66-108$ & 84 & 73 & 86 & 76 \\
\hline Oat & $66-138$ & 76 & 66 & - & 75 \\
\hline \multicolumn{6}{|l|}{ Plant protein sources } \\
\hline Pea & $170-236$ & 79 & 74 & 76 & 87 \\
\hline Lupins & $284-440$ & 87 & 84 & 86 & 90 \\
\hline Soybean meal (fibre < $4.5 \%$ ) & $438-498$ & 88 & 85 & 90 & 87 \\
\hline Soybean meal (fibre > $4.5 \%$ ) & $390-485$ & 86 & 83 & - & 85 \\
\hline Rapeseed meal & $308-403$ & 72 & 70 & 76 & 76 \\
\hline Sunflower meal & $324-438$ & 80 & 78 & 84 & 85 \\
\hline DDGS-maize & $238-292$ & 73 & 69 & - & - \\
\hline DDGS-wheat & $246-402$ & 77 & 74 & - & - \\
\hline \multicolumn{6}{|l|}{ Animal protein sources } \\
\hline Fish meal & $506-749$ & 85 & 83 & 80 & 88 \\
\hline Meat bone meal & $413-497$ & 59 & 57 & 65 & 73 \\
\hline
\end{tabular}

${ }^{1} \mathrm{SID}=$ standardized ileal digestibility; $\mathrm{AID}=$ apparent ileal digestibility; $\mathrm{ATTD}=$ apparent total tract digestibility. Reference: Lemme et al. (2004); CVB (2016).

Apart from the intrinsic characteristics of protein sources, protein digestion is also significantly affected by the digestive capacity of animals. Broilers showed a higher (i.e. 2-10 \%) ileal protein digestibility than pigs for most cereal grains and vegetable protein sources (Table 1.1). This is likely due to the fact that broilers have a greater size of the GIT relative to their body than pigs (Table 1.2). In addition, protein digestion requires adequate interactions between digestive enzymes and dietary protein. $A$ fast 
passage rate of digesta along the GIT, therefore, might hinder protein digestion. On average, pigs have a longer retention time of digesta in the stomach and the small intestine than poultry (Weurding et al., 2001; Wilfart et al., 2007; Liu et al., 2013). The passage rate of digesta along the GIT depends also on the feeding pattern (i.e. feeding frequency and meal quantity) and the physicochemical properties (e.g. solubility, viscosity, and water binding capacity) of digesta. A large volume of a meal (Hunt and Stubbs, 1975), a high solubility of digesta (Low et al., 1978) and an increase in dietary fibre content (Wilfart et al., 2007) decrease the passage rate of digesta along the GIT.

Table 1.2. Comparison of the dimensions of the gastrointestinal tract (GIT) of pigs and broilers.

\begin{tabular}{lcc}
\hline Item & Pig & Broiler \\
\hline Body weight (kg) & 50 & 1.5 \\
Weight relative to live body weight (\%) & 3.5 & 7.8 \\
$\quad$ GIT & 0.5 & $3.0^{1}$ \\
$\quad$ Stomach & 1.6 & 3.3 \\
$\quad$ Small intestine & 1750 & 163 \\
Length of small intestine (cm) & 4 & 20 \\
Length relative to small intestine length (\%) & 91 & 35 \\
$\quad$ Duodenum & 4 & 45 \\
$\quad$ Jejunum & 4 . & \\
$\quad$ leum & & \\
${ }^{1}$ The weight of proventriculus and gizzard. Reference: Barea et al. (2011); Mabelebele et al. \\
(2014).
\end{tabular}

Even though several factors related to both intrinsic characteristics of protein sources and to digestive physiology of animals have been attributed to the differences in the extent of in vivo protein digestion, current knowledge, however, is still limited and has not elucidated complicated mechanisms causing differences in protein digestion among protein sources. 


\section{Protein evaluation in pig and poultry diets}

In current feed evaluation systems, the nutritional value of protein sources in pig and poultry diets is based on digestible AAs at the end of the ileum as dietary protein degraded in the hindgut by microbial fermentation, does not significantly contribute to AA supply for animals (Lemme et al., 2004; Ravindran et al., 2005; NRC, 2012; CVB, 2016).

Protein and AA digestibility of protein sources can be evaluated via both in vitro and in vivo approaches. In vivo ileal protein and AA digestibility are determined and calculated using ileal digesta collected via ileal-cannulated animals or sampled under anaesthesia of animals. Compared to in vivo approaches, in vitro approaches are relatively fast and cheap methods, that can be used to obtain an estimate for the protein digestibility of different feed ingredients. Various in vitro methods have been developed to estimate protein and AA digestibility of feed ingredients for pigs (Hsu et al., 1977; Babinszky et al., 1990; Boisen and Fernández, 1995; Huang et al., 2000). In these methods, feed ingredients are incubated sequentially with different enzymes, such as pepsin, pancreatin, trypsin, chymotrypsin and peptidases, to simulate gastric and intestinal protein digestion. Generally, these methods are static methods. They generate a single in vitro digestibility value for nitrogen $(N)$ or crude protein $(N \times 6.25)$ after a fixed period of incubation. The in vitro digestibility of protein is determined as the solubility of $\mathrm{N}$ in the sample, assuming that $\mathrm{N}$ present in soluble form is absorbed in the GIT in vivo. However, around 50 \% of unabsorbed $\mathrm{N}$ was present as soluble $\mathrm{N}$ in ileal digesta of pigs (Hulshof et al., 2016), indicating that this assumption is incorrect. Moreover, endogenous protein secretions in the GIT and the transition of digesta along the GIT are not taken into account in these static methods. As a consequence, in vitro digestibility values are not well-correlated with in vivo digestibility values (Table 1.3).

Compared to static models, a multicompartmental and dynamic model, such as the TNO intestinal model (TIM), might have a more accurate simulation of protein digestion in vivo. This model is able to simulate peristaltic mixing and transition of digesta, continuous addition of endogenous secretions, and absorption of digestion end products via dialysis (Minekus et al., 1995). However, it can still not fully mimic in vivo digestion due to the limitations on simulating responses of the intestinal mucosa and commensal microbiota to dietary compounds. 
Table 1.3. Overview of in vitro protein digestibility of feed ingredients using different incubation conditions.

\begin{tabular}{|c|c|c|c|c|c|c|c|}
\hline Reference & Enzymes & $\mathrm{pH}$ & Time & Temperature & Ingredient & In vitro & In vivo \\
\hline \multirow{4}{*}{$\begin{array}{l}\text { Hsu et al., } \\
1977\end{array}$} & \multirow{4}{*}{$\begin{array}{l}\text { Trypsin } \\
\text { Chymotrypsin } \\
\text { Peptidase }\end{array}$} & \multirow{4}{*}{8.0} & \multirow{4}{*}{$10 \mathrm{~min}$} & \multirow{4}{*}{$37^{\circ} \mathrm{C}$} & Wheat flour & 82 & 86 \\
\hline & & & & & Soy concentrate & 90 & 90 \\
\hline & & & & & Cottonseed meal & 88 & 87 \\
\hline & & & & & Full lactose whey & 85 & 81 \\
\hline \multirow{4}{*}{$\begin{array}{l}\text { Babinszky } \\
\text { et al., } 1990\end{array}$} & & & & & Soybean meal & 88 & 90 \\
\hline & Pepsin & 1.0 & $1.5 \mathrm{~h}$ & $40^{\circ} \mathrm{C}$ & Linseed expeller & & \\
\hline & Pancreatin & 6.8 & $1.0 \mathrm{~h}$ & $40^{\circ} \mathrm{C}$ & Lupin & 83 & 91 \\
\hline & & & & & Rapeseed meal & 77 & 81 \\
\hline \multirow{6}{*}{$\begin{array}{l}\text { Boisen and } \\
\text { Fernández, } \\
1995\end{array}$} & & & & & Soybean meal & 93 & 78 \\
\hline & & & & & Rapeseed meal & 84 & 69 \\
\hline & Pepsin & 2.0 & $6 \mathrm{~h}$ & $39^{\circ} \mathrm{C}$ & Sunflower meal & 91 & 73 \\
\hline & Pancreatin & 6.8 & $18 \mathrm{~h}$ & $39^{\circ} \mathrm{C}$ & Peas & 96 & 80 \\
\hline & & & & & Meat and bone meal & 85 & 56 \\
\hline & & & & & Skim milk powder & 100 & 86 \\
\hline \multirow{4}{*}{$\begin{array}{l}\text { Huang et } \\
\text { al., } 2000\end{array}$} & & & & & Fish meal (Peru) & 58 & 83 \\
\hline & Pepsin & 2.0 & $4 \mathrm{~h}$ & $37^{\circ} \mathrm{C}$ & Fish meal (China) & 48 & 81 \\
\hline & Pancreatin & 7.6 & $24 \mathrm{~h}$ & $37^{\circ} \mathrm{C}$ & Rapeseed meal & 56 & 89 \\
\hline & & & & & Cottonseed meal & 52 & 86 \\
\hline
\end{tabular}

\section{Classification of fast and slow protein sources}

The classification of fast and slow protein sources was first proposed by Boirie et al. (1997) when feeding casein and whey protein to human subjects. Both whey protein and casein are considered highly digestible in humans (Hambraeus and Lönnerdal, 2003). They, however, displayed differences in the timing and the extent of postprandial increase of plasma AAs. Whey protein induced a pronounced but transient postprandial increase of plasma AAs, whereas casein induced a smaller but more prolonged postprandial increase of AAs and peptides in plasma (Boirie et al., 1997). Thus, based on the timing and the extent of postprandial increase of plasma AAs and peptides, protein sources can be categorised into fast and slow protein sources (Boirie et al., 1997; Bos et al., 2003; Tang et al., 2009) (Figure 1.1). Usually, categorisation of fast and slow protein sources is done based on the judgement of the postprandial increase in plasma AA concentration. Analysis of the postprandial plasma AAs curves by calculating increase and elimination rates using mathematical equations are rarely done in studies comparing fast and slow protein sources. As a result, quantitative information on differences in protein digestion kinetics among protein sources is hardly available. 


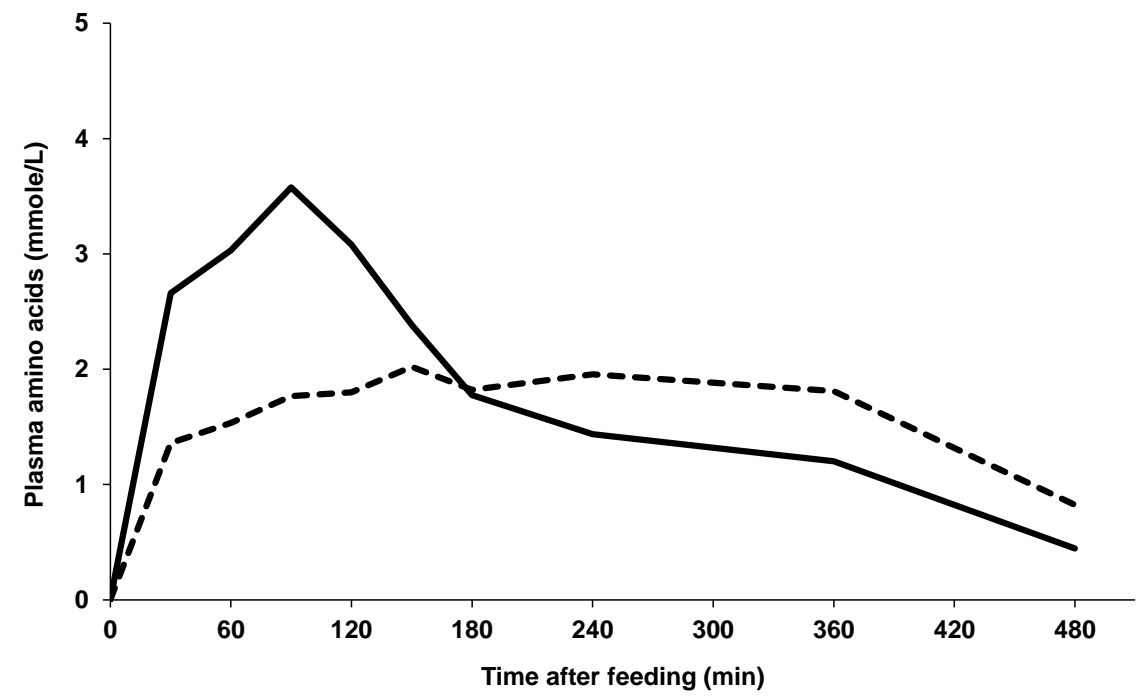

Figure 1.1. Example of postprandial increase of plasma amino acids of fast protein (solid line) and slow protein (dashed line) after meal ingestion based on the results of the present thesis (Chapter 3).

\section{Factors affecting postprandial increase of plasma amino acids}

The timing and the extent of the postprandial increase of plasma AAs are related to four aspects: 1) the passage rate of digesta along the GIT, 2) the hydrolysis rate of dietary protein, 3) the absorption rate of AAs and peptides by the small intestinal mucosa and 4) the metabolism of AAs and peptides by the small intestinal mucosa. Studies have shown that a more rapid and pronounced postprandial increase of plasma AAs could be related to a fast gastric emptying of dietary protein. In the study of Boirie et al. (1997), the rapid and pronounced postprandial increase of plasma leucine observed in human subjects ingesting whey protein might be due to the fast gastric emptying of whey protein. Whey protein remains soluble in the stomach, whereas casein coagulates. The liquid fraction is emptied faster from the stomach to the small intestine than the solid fraction (Low, 1990). Similar results were observed in a pig study, where milk fed in a gel form showed a delayed $\mathrm{N}$ flow from the stomach to the small intestine compared to pigs fed milk in liquid form, resulting in a delayed and less pronounced postprandial increase of plasma AAs (Barbé et al., 2013).

Apart from the gastric emptying, a fast hydrolysis of dietary protein and absorption of AAs can also be attributed to a more rapid increase of plasma AAs after ingestion of a 
meal. It is demonstrated in human studies that ingestion of protein hydrolysates result in a faster and greater postprandial increase of AAs than ingestion of their nonhydrolysed equivalents (Calbet and Holst, 2004; Koopman et al., 2009; Morifuji et al., 2010). This can be related to protein hydrolysates requiring less hydrolysis in the small intestine prior to absorption in the form of peptides and free AAs. Another example is that in pigs, soy protein concentrate showed a more rapid portal appearance of AAs than a mixture of untoasted and toasted soybean meal after meal ingestion (Jansman et al., 1997). The difference might be partly explained by a higher trypsin inhibitor activity in the diet with a mixture of untoasted and toasted soybean meal, resulting in a lower rate of hydrolysis of dietary protein.

The intestinal mucosa also plays an important role in regulating the timing and determining the extent of postprandial appearance of plasma AAs due to its extensive metabolism of AAs. Amino acids are the major energy source for the intestinal enterocytes, of which glutamate is the main fuel for the intestinal enterocytes via glutaminolysis. In piglets, as much as $95 \%$ of glutamate is metabolized by the intestinal enterocytes (Stoll et al., 1998). Apart from glutamate, glutamine and branched-chain AAs can be metabolised into glutamate and, therefore, are also highly catabolised in the intestinal mucosa with the purpose of energy production (Wu, 1998; Chen et al., 2007). In addition to energy production, AAs are also metabolised in the intestinal enterocytes for maintaining intestinal mucosal mass and for the synthesis of metabolites, such as glutathione and nitric oxide, which are critical for regulating integrity of intestinal mucosa (Wu, 1998).

\section{Effects of fast and slow protein sources on post-absorption protein metabolism}

An efficient utilisation of dietary AAs for muscle protein synthesis is economically important in production animals, particularly with the forthcoming global protein scarcity. Amino acids are used by organs and tissues, either or not after transformation into other AAs, to synthesise proteins or as an energy source after deamination. The efficiency of protein utilisation depends on the balance between these two processes, in which a higher efficiency relates to a higher body protein synthesis (Figure 1.2). 


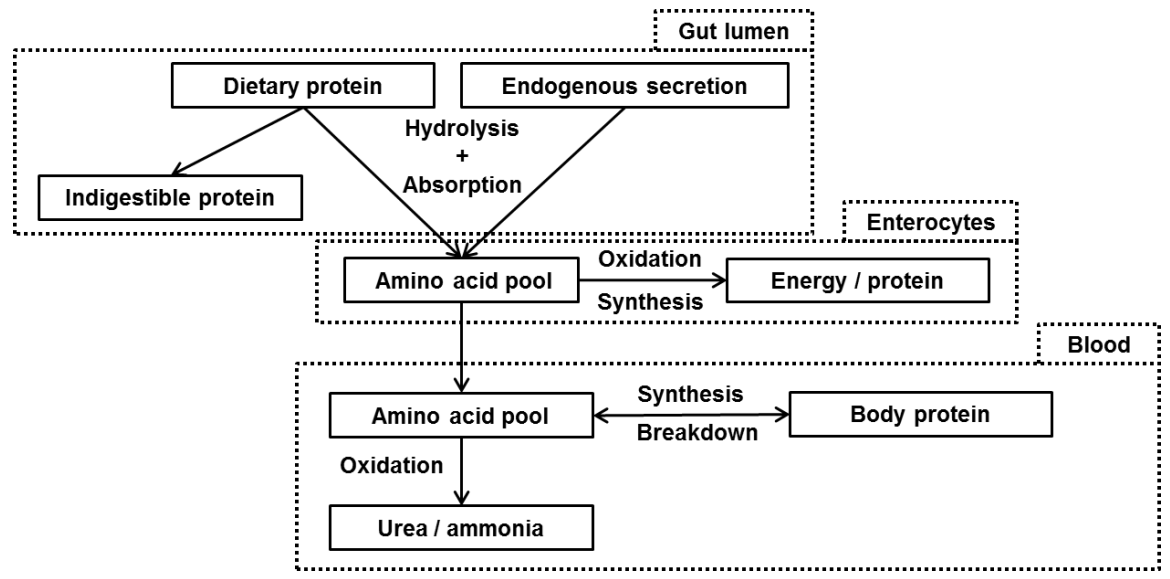

Figure 1.2. Schematic overview of post-absorption metabolism of dietary protein (adapted from Frühbeck, 1998 and Sauer et al., 2000).

Muscle protein synthesis is significantly stimulated after meal ingestion. This is due to the action of insulin, which increases protein synthesis in skeletal muscle (Davis et al., 1996; Svanberg et al., 1996). The effect of insulin on skeletal muscle protein synthesis, however, is 4.5 times higher in neonatal pigs than in weaning pigs (Davis et al., 1996). In addition to insulin, dietary essential AAs, especially leucine, exert a significant regulatory effect on muscle protein synthesis via the mammalian target of rapamycin (mTOR) pathway in both pigs and poultry (Suryawan et al., 2008; Deng et al., 2013).

The simultaneous availability of energy and AAs are prerequisite for protein synthesis (Geiger, 1950). Starch, provided by cereal grains such as wheat, maize and barley, is the main energy source in pig and poultry diets. Starch hydrolysis and glucose absorption mainly take place in the duodenum and proximal jejunum (Riesenfeld et al., 1980; Knudsen et al., 2006), whereas protein hydrolysis and AA absorption mainly take place in the jejunum and is completed in the ileum (Low, 1980; Sklan and Hurwitz, 1980). This suggests that dietary starch on average is digested faster than dietary protein along the GIT, which might lead to an asynchronous supply of energy and protein in the case of meal fed animals or humans. Indeed, pigs fed pea starch, a slowly digestible source, showed an increased essential AA flux into portal circulation by $12 \%$ compared to pigs fed maize starch, a fast digestible starch (van der Meulen et al., 1997). The increase in AA appearance in the portal vein was suggested to be related to the release of glucose in the distal part of the small intestine from slowly digestible starch, thereby sparing AAs from being catabolised to produce energy. Broilers fed diets with more slowly 
digestible starch increased body weight gain with $5 \%$ and decreased feed conversion ratio by $2 \%$ (Weurding et al., 2003). In addition, $\mathrm{N}$ retention was negatively correlated to the starch digestion rate in broilers fed sorghum-based diets $(r=-0.39)$, indicating slowly digestible starch increased protein retention in broilers (Liu et al., 2013). Thus, the fate of dietary AAs in the post absorptive metabolism depends on the kinetics of protein digestion relative to the digestion kinetics of energy providing nutrients in the diet such as starch.

\section{Formulation of the knowledge gaps}

Protein digestion involves many different processes, including enzymatic hydrolysis of proteins and peptides, secretion of digestive enzymes, transit of digesta, absorption of peptides and AAs, and protein fermentation by intestinal microbiota. Most currently applied in vitro and in vivo techniques for determining protein digestibility provide end-point values related to the quantity of proteins absorbed from the GIT up to the end of the ileum, with or without the correction for basal endogenous protein loss. They, however, do not provide information on the kinetics of protein digestion, which could significantly affect the post-absorption metabolism of AAs originating from dietary protein. Although some studies focusing on protein digestion kinetics have been performed in humans, they mainly focused on milk proteins. The kinetics of protein digestion of feed ingredients used in pig and poultry diets remains largely unknown. Information on protein digestion kinetics of protein sources can be used to further develop the concept of synchronising the dietary supply of energy and protein, which could improve protein retention and overall protein utilisation efficiency in pigs and poultry.

\section{Aim and outline of the thesis}

The aim of the present thesis was to provide further insight into the digestion kinetics of dietary protein along the GIT of pigs and poultry. First, a modified two-step in vitro approach was applied to screen the kinetics of $\mathrm{N}$ solubilisation and the release of low molecular weight peptides (<500 Da) for various protein sources (Chapter 2). Based on the in vitro results, five protein sources (i.e. soybean meal, rapeseed meal, wheat gluten, dried porcine plasma protein and black solder fly larvae) were selected for 
further investigation. The in vivo protein digestion kinetics of these five protein sources were determined in both pigs (Chapter 3 ) and broiler chickens (Chapter 4). The in vivo protein digestion kinetics was evaluated with respect to the apparent disappearance of dietary crude protein fraction from the small intestine and the change in molecular weight distribution of proteins and peptides present in digesta. After the differences in protein digestion kinetics among protein sources, both in vitro and in vivo, were identified, the effects of synchronising dietary protein and starch using information on their kinetics of digestion on the growth performance and carcass characteristics in broilers were investigated (Chapter 5). Finally, the results presented in this thesis are discussed (Chapter 6). 


\section{REFERENCES}

Babinszky, L., J. M. van der Meer, H. Boer, and L. A. den Hartog. 1990. An in-vitro method for prediction of the digestible crude protein content in pig feeds. J. Sci. Food Agric. 50:173-178.

Barbé, F., O. Ménard, Y. Le Gouar, C. Buffière, M. H. Famelart, B. Laroche, S. Le Feunteun, D. Dupont, and D. Rémond. 2013. The heat treatment and the gelation are strong determinants of the kinetics of milk proteins digestion and of the peripheral availability of amino acids. Food Chem. 136:1203-1212.

Barea, R., R. Nieto, F. Vitari, C. Domeneghini, and J. F. Aguilera. 2011. Effects of pig genotype (Iberian v. Landrace $\times$ Large White) on nutrient digestibility, relative organ weight and small intestine structure at two stages of growth. Animal 5:547-557.

Boirie, Y., M. Dangin, P. Gachon, M. P. Vasson, J. L. Maubois, and B. Beaufrère. 1997. Slow and fast dietary proteins differently modulate postprandial protein accretion. Proc. Natl. Acad. Sci. 94:14930-14935.

Boisen, S., and J. A. Fernández. 1995. Prediction of the apparent ileal digestibility of protein and amino acids in feedstuffs and feed mixtures for pigs by in vitro analyses. Anim. Feed Sci. Technol. 51:29-43.

Bos, C., C. C. Metges, C. Gaudichon, K. J. Petzke, M. E. Pueyo, C. Morens, J. Everwand, R. Benamouzig, and D. Tomé. 2003. Postprandial kinetics of dietary amino acids are the main determinant of their metabolism after soy or milk protein ingestion in humans. J. Nutr. 133:1308-1315.

Calbet, J. A. L., and J. J. Holst. 2004. Gastric emptying, gastric secretion and enterogastrone response after administration of milk proteins or their peptide hydrolysates in humans. Eur. J. Nutr. 43:127-139.

Carbonaro, M., P. Maselli, and A. Nucara. 2012. Relationship between digestibility and secondary structure of raw and thermally treated legume proteins: a Fourier transform infrared (FT-IR) spectroscopic study. Amino Acids 43:911-921.

Chen, L., Y. Yin, W. S. Jobgen, S. C. Jobgen, D. A. Knabe, W. Hu, and G. Wu. 2007. In vitro oxidation of essential amino acids by jejunal mucosal cells of growing pigs. Livest. Sci. 109:19-23.

CVB. 2016. Chemical compositions and nutritional values of feed ingredients. Centraal Veevoeder Bureau, Wageningen, the Netherlands.

Davis, T. A., D. G. Burrin, M. L. Fiorotto, and H. V. Nguyen. 1996. Protein synthesis in skeletal muscle and jejunum is more responsive to feeding in 7-than in 26-day-old pigs. Am. J. Physiol. Metab. 270:E802E809.

Deng, H. L., A. J. Zheng, G. H. Liu, W. H. Chang, S. Zhang, and H. Y. Cai. 2013. Activation of mammalian target of rapamycin signalling in skeletal muscle of neonatal chicks: Effects of dietary leucine and age. Poult. Sci. 93:114-121.

Erickson, R. H., and Y. S. Kim. 1990. Digestion and absorption of dietary protein. Annu. Rev. Med. 41:133-139.

FAOSTAT. 2009. Statistical databases. Food and Agriculture Organization of the United Nations, Rome, Italy.

Folk, J. E., K. A. Piez, W. R. Carroll, and J. A. Gladner. 1960. Carboxypeptidase B IV. Purification and characterization of the porcine enzyme. J. Biol. Chem. 235:2272-2277.

Frühbeck, G. 1998. Protein metabolism: slow and fast dietary proteins. Nature 391:843-845.

Ganapathy, V., M. E. Ganapathy, and F. H. Leibach. 2000. Intestinal transport of peptides and amino acids. Curr. Top. Membr. 50:379-412.

Geiger, E. 1950. The role of the time factor in protein synthesis. Science. 111:594-599.

Godfray, H. C. J., J. R. Beddington, I. R. Crute, L. Haddad, D. Lawrence, J. F. Muir, J. Pretty, S. Robinson, S. M. Thomas, and C. Toulmin. 2010. Food security: the challenge of feeding 9 billion people. Science 327:812-818.

Hambraeus, L., and B. Lönnerdal. 2003. Nutritional aspects of milk proteins. In: advanced dairy chemistry-1 proteins. Springer, USA. pp. 605-645.

Hamuro, Y., S. J. Coales, K. S. Molnar, S. J. Tuske, and J. A. Morrow. 2008. Specificity of immobilized porcine pepsin in H/D exchange compatible conditions. Rapid Commun. Mass Spectrom. 22:1041-1046.

Hsu, H. W., D. L. Vavak, L. D. Satterlee, and G. A. Miller. 1977. A multienzyme technique for estimating protein digestibility. J. Food Sci. 42:1269-1273. 
Huang, R. L., Z. L. Tan, T. X. Xing, Y. F. Pan, and T. J. Li. 2000. An in vitro method for the estimation of ileal crude protein and amino acids digestibility using the dialysis tubing for pig feedstuffs. Anim. Feed Sci. Technol. 88:79-89.

Hulshof, T. G., A. F. B. van der Poel, W. H. Hendriks, and P. Bikker. 2016. Processing of soybean meal and 00rapeseed meal reduces protein digestibility and pig growth performance but does not affect nitrogen solubilization along the small intestine. J. Anim. Sci. 94:2403-2414.

Hunt, J. N., and D. F. Stubbs. 1975. The volume and energy content of meals as determinants of gastric emptying. J. Physiol. 245:209-225.

Jansman, A. J. M., P. van Leeuwen, W. Crala, and I. Haaksman. 1997. Dynamics of amino acids absorption in pigs. Proc. of the 7th Int. Symp. on Dig. Physiol. in Pigs, Saint Malmo, France. pp.316-320.

Knudsen, K. E. B., H. N. Lærke, S. Steenfeldt, M. S. Hedemann, and H. Jørgensen. 2006. In vivo methods to study the digestion of starch in pigs and poultry. Anim. Feed Sci. Technol. 130:114-135.

Koopman, R., N. Crombach, A. P. Gijsen, S. Walrand, J. Fauquant, A. K. Kies, S. Lemosquet, W. H. M. Saris, Y. Boirie, and L. J. C. van Loon. 2009. Ingestion of a protein hydrolysate is accompanied by an accelerated in vivo digestion and absorption rate when compared with its intact protein. Am. J. Clin. Nutr. 90:106115.

Lemme, A., V. Ravindran, and W. L. Bryden. 2004. Ileal digestibility of amino acids in feed ingredients for broilers. Worlds. Poult. Sci. J. 60:423-438.

Liu, S. Y., P. H. Selle, and A. J. Cowieson. 2013. The kinetics of starch and nitrogen digestion regulate growth performance and nutrient utilisation of broilers fed coarsely ground, sorghum-based diets. Anim. Prod. Sci. 53:1033-1040.

Low, A. G., I. Partridge, and I. Sambrook. 1978. Studies on digestion and absorption in the intestines of growing pigs. Br. J. Nutr. 39:515-526.

Low, A. G. 1980. Nutrient absorption in pigs. J. Sci. Food Agric. 31:1087-1130.

Low, A. G. 1990. Nutritional regulation of gastric secretion, digestion and emptying. Nutr. Res. Rev. 3:229252.

Mabelebele, M., O. J. Alabi, J. W. Ngambi, D. Norris, and M. M. Ginindza. 2014. Comparison of gastrointestinal tracts and $\mathrm{pH}$ values of digestive organs of Ross 308 broiler and indigenous Venda chickens fed the same diet. Asian J. Anim. Vet. Adv. 9:71-76.

Malabat, C., and C. Rabiller. 2001. Emulsifying and foaming properties of native and chemically modified peptides from the 2S and 12S proteins of rapeseed (Brassica napus L.). J. Am. Oil Chem. 78:235-242.

Mangan, J. L. 1988. Nutritional effects of tannins in animal feeds. Nutr. Res. Rev. 1:209-231.

Minekus, M., P. Marteau, and R. Havenaar. 1995. Multicompartmental dynamic computer-controlled model simulating the stomach and small intestine. Altern. Lab. Anim. 23:197-209

Morifuji, M., M. Ishizaka, S. Baba, K. Fukuda, H. Matsumoto, J. Koga, M. Kanegae, and M. Higuchi. 2010. Comparison of different sources and degrees of hydrolysis of dietary protein: effect on plasma amino acids, dipeptides, and insulin responses in human subjects. J. Agric. Food Chem. 58:8788-8797.

Nousiainen, J. 1991. Comparative observations on selected probiotics and olaquindox as feed additives for piglets around weaning. J. Anim. Physiol. Anim. Nutr. 66:224-230.

NRC. 2012. Nutrient requirements of swine. Eleventh revised edition. National Academic Press, Washington, D.C., USA.

Ravindran, V., L. I. Hew, G. Ravindran, and W. L. Bryden. 2005. Apparent ileal digestibility of amino acids in dietary ingredients for broiler chickens. Anim. Sci. 81:85-97.

Rehman, H. U., W. Vahjen, W. A. Awad, and J. Zentek. 2007. Indigenous bacteria and bacterial metabolic products in the gastrointestinal tract of broiler chickens. Arch. Anim. Nutr. 61:319-335.

Riesenfeld, G., D. Sklan, A. Bar, U. Eisner, and S. Hurwitz. 1980. Glucose absorption and starch digestion in the intestine of the chicken. J. Nutr. 110:117-121.

Riviere, L. R., and P. Tempst. 2001. Enzymatic digestion of proteins in solution. Curr. Protoc. Protein Sci. 11:19.

Rubio, L. A., A. Pérez, R. Ruiz, M. Guzman, I. Aranda-Olmedo, and A. Clemente. 2014. Characterization of pea (Pisum sativum) seed protein fractions. J. Sci. Food Agric. 94:280-287. 
Salazar-Villanea, S., E. M. A. M. Bruininx, H. Gruppen, P. Carré, A. Quinsac, and A. F. B. van der Poel. 2017. Effects of toasting time on digestive hydrolysis of soluble and insoluble 00 -rapeseed meal proteins. J. Am. Oil Chem. Soc. 94:619-630.

Sauer, W. C., M. Z. Fan, R. Mosenthin, and W. Drochner. 2000. Methods for measuring ileal amino acid digestibility in pigs. Farm Anim. Metab. Nutr. CABI Publishing, NY, USA. pp.279-306.

Schwenke, K. D., B. Drescher, D. Zirwer, and B. Raab. 1988. Structural studies on the native and chemically modified low molecular mass basic storage protein (Napin) from rapeseed (Brassica napus L.). Biochem. Physiol. Pflanz. 183:219-224.

Selle, P. H., A. J. Cowieson, N. P. Cowieson, and V. Ravindran. 2012. Protein-phytate interactions in pig and poultry nutrition: a reappraisal. Nutr. Res. Rev. 25:1-17.

Sklan, D., and S. Hurwitz. 1980. Protein digestion and absorption in young chicks and turkeys. J. Nutr. 110:139-144.

Steinfeld, H., P. Gerber, T. D. Wassenaar, V. Castel, and C. de Haan. 2006. Livestock's long shadow: environmental issues and options. Food and Agriculture Organization of the United Nations, Rome, Italy.

Stoll, B., J. Henry, P. J. Reeds, H. Yu, F. Jahoor, and D. G. Burrin. 1998. Catabolism dominates the first-pass intestinal metabolism of dietary essential amino acids in milk protein-fed piglets. J. Nutr. 128:606-614.

Suryawan, A., A. S. Jeyapalan, R. A. Orellana, F. A. Wilson, H. V. Nguyen, and T. A. Davis. 2008. Leucine stimulates protein synthesis in skeletal muscle of neonatal pigs by enhancing mTORC1 activation. Am. J. Physiol. Metab. 295:868-875.

Svanberg, E., H. Zachrisson, C. Ohlsson, B. M. Iresjo, and K. G. Lundholm. 1996. Role of insulin and IGF-I in activation of muscle protein synthesis after oral feeding. Am. J. Physiol. Metab. 270:614-620.

Tang, J. E., D. R. Moore, G. W. Kujbida, M. A. Tarnopolsky, and S. M. Phillips. 2009. Ingestion of whey hydrolysate, casein, or soy protein isolate: effects on mixed muscle protein synthesis at rest and following resistance exercise in young men. J. Appl. Physiol. 107:987-992.

Tonheim, S. K., A. Nordgreen, I. Høgøy, K. Hamre, and I. Rønnestad. 2007. In vitro digestibility of watersoluble and water-insoluble protein fractions of some common fish larval feeds and feed ingredients. Aquaculture 262:426-435.

UN. 2015. World population prospects: the 2015 revision, key findings and advance tables. United Nations, Department of Economic and Social Affairs, Population Division, NY, USA.

van der Meulen, J., J. G. M. Bakker, B. Smits, and H. de Visser. 1997. Effect of source of starch on net portal flux of glucose, lactate, volatile fatty acids and amino acids in the pig. Br. J. Nutr. 78:533-544.

Veldkamp, T., G. van Duinkerken, A. van Huis, C. M. M. Lakemond, E. Ottevanger, G. Bosch, and T. van Boekel. 2012. Insects as a sustainable feed ingredient in pig and poultry diets: a feasibility study, Wageningen UR Livestock Research, Wageningen, the Netherlands.

Visek, W. J. 1984. Ammonia: its effects on biological systems, metabolic hormones, and reproduction. J. Dairy Sci. 67:481-498.

Webb, K. E., J. C. Matthews, and D. B. DiRienzo. 1992. Peptide absorption: a review of current concepts and future perspectives. J. Anim. Sci. 70:3248-3257.

Weurding, R. E., A. Veldman, W. A. G. Veen, P. J. van der Aar, and M. W. A. Verstegen. 2001. Starch digestion rate in the small intestine of broiler chickens differs among feedstuffs. J. Nutr. 131:2329-2335.

Weurding, R. E., H. Enting, and M. W. A. Verstegen. 2003. The effect of site of starch digestion on performance of broiler chickens. Anim. Feed Sci. Technol. 110:175-184.

Wilfart, A., Y. Jaguelin-Peyraud, H. Simmins, J. Noblet, J. van Milgen, and L. Montagne. 2007. A step-wise in vitro method to estimate kinetics of hydrolysis of feeds. Livest. Sci. 109:179-181.

Williams, B. A., M. W. A. Verstegen, and S. Tamminga. 2001. Fermentation in the large intestine of singlestomached animals and its relationship to animal health. Nutr. Res. Rev. 14:207-228.

Wu, G. 1998. Intestinal mucosal amino acid catabolism. J. Nutr. 128:1249-1252. 
24|P a ge 
Chapter 2

\title{
In vitro protein digestion kinetics of protein sources for pigs
}

\author{
H. Chen ${ }^{*}$, P.A. Wierenga ${ }^{\dagger}$, W.H. Hendriks ${ }^{*}$, A.J.M. Jansman ${ }^{\ddagger}$
}

*Animal Nutrition Group, Wageningen University \& Research, The Netherlands

${ }^{\dagger}$ Laboratory of Food Chemistry, Wageningen University \& Research, The Netherlands

${ }^{\ddagger}$ Wageningen Livestock Research, The Netherlands 


\section{ABSTRACT}

The objective of the present study was to determine the in vitro protein digestion kinetics of different protein sources (soybean meal (SBM), wheat gluten (WG), rapeseed meal (RSM), whey powder (WP), dried porcine plasma protein (DPP), yellow meal worm larvae (MW), and black soldier fly larvae (BSF)). Protein sources were incubated with pepsin at $\mathrm{pH} 3.5$ for $0-90 \mathrm{~min}$ and subsequently with pancreatin at $\mathrm{pH} 6.8$ for $0-210$ min at $39{ }^{\circ} \mathrm{C}$. The in vitro protein digestion kinetics were described as the kinetics of nitrogen $(\mathrm{N})$ solubilisation and the release of low molecular weight peptides (<500 Da). The $\mathrm{N}$ solubilisation rate ranged from $0.025 \mathrm{~min}^{-1}$ for BSF to $0.685 \mathrm{~min}^{-1}$ for WP during the incubation with pepsin, and from $0.027 \mathrm{~min}^{-1}$ for RSM to $0.343 \mathrm{~min}^{-1}$ for WP during the incubation with pancreatin. The release rate of low molecular weight peptides ranged from $0.027 \mathrm{~min}^{-1}$ for WG to $0.093 \mathrm{~min}^{-1}$ for WP during the incubation with pepsin, and from $0.029 \mathrm{~min}^{-1}$ for SBM to $0.385 \mathrm{~min}^{-1}$ for WP. At the end of the sequential incubation with pepsin (90 min) and pancreatin (210 min), WG and WP showed the highest percentage of $\mathrm{N}$ present in low molecular weight peptides relative to total $\mathrm{N}$ (78 and $79 \%$, respectively), whereas SBM showed the lowest (35\%). In conclusion, protein sources for pig diets show substantial differences in in vitro protein digestion kinetics as measured by the kinetics of $\mathrm{N}$ solubilisation and the release of low molecular weight peptides. The rate of release of low molecular weight peptides was not correlated to the rate of $\mathrm{N}$ solubilisation for each of the protein sources evaluated.

\section{IMPLICATION}

The animal feed industry is facing the challenge of contributing to the provision of sufficient food of animal-origin to the growing world population while simultaneously improving environmental sustainability of animal production systems. Therefore, there is a need to use feed ingredients more efficiently in animal production. Information on protein digestion kinetics of protein sources using in vitro approaches can be used to further develop the concept of synchronising the dietary supply of energy and protein, which could improve protein retention and efficiency in production animals. 


\section{INTRODUCTION}

In current feed evaluation systems, the nutritional value of protein sources in diets for pigs is based on the concentration and ratio of indispensable amino acids, and their digestibility up to the end of ileum (CVB, 2016; NRC, 2012). The ileal digestibility of protein and amino acids only provides information on the quantity of proteins and amino acids apparently absorbed from the gastrointestinal tract (GIT) up to the end of the ileum. Such data do not account for the kinetics of protein digestion along the GIT. Additional information on protein digestion kinetics may help to understand the timing of delivery of amino acids and peptides from dietary proteins along the GIT.

Protein sources with comparable ileal protein digestibility can differ in the kinetics of protein digestion, thereby affecting the postprandial appearance of amino acids and peptides in blood and their post-absorptive metabolism (Mahé et al., 1995; Boirie et al., 1997; Dangin et al., 2001). In humans, fast digestible dietary proteins such as whey protein show an earlier postprandial appearance of amino acids and peptides in blood compared to more slowly digestible sources such as casein (Boirie et al., 1997). The timing of postprandial appearance of amino acids and peptides in blood may relate to the release kinetics of free amino acids or di- and tri-peptides during the process of protein digestion. The release kinetics of free amino acids or di- and tri-peptides can be affected by the chemical composition, the structure of constituting proteins, and the physicochemical properties (e.g. solubility) of protein sources. For instance, the in vitro hydrolysis rate of a water-soluble form of casein (i.e. $\mathrm{Na}^{+}$-caseinate) was almost twice as high compared to that of water-insoluble casein at pH 8.0 (Tonheim et al., 2007).

Protein digestion along the GIT can be simulated in vitro by incubating protein sources with pepsin and pancreatin sequentially using incubation conditions as prevailing in the GIT. Various in vitro methods have been developed to estimate protein digestibility of feed ingredients for pigs (Babinszky et al., 1990; Cone and van der Poel, 1993; Boisen and Fernández, 1995). Generally, these methods are end point methods, meaning that they generate a single in vitro digestibility value for nitrogen $(\mathrm{N})$ or crude protein $(\mathrm{N} \times 6.25)$ after incubation for a fixed period of time. The in vitro digestibility of protein is determined as the solubility of $\mathrm{N}$ in the sample, assuming that $\mathrm{N}$ present in soluble form is absorbed in the GIT in vivo. However, in vivo dietary proteins need to be hydrolysed into free amino acids or di- and tri-peptides before they can be absorbed by enterocytes in the small intestinal mucosa (Webb et al., 1992; Ganapathy et al., 2000). Protein sources with a similar in vitro protein digestibility based on determination of $\mathrm{N}$ 
solubility can differ in the extent of release of free amino acids or di- and tri-peptides. Current in vitro methods for estimating protein digestibility do not take this into account. Rather than measuring only the change in $\mathrm{N}$ solubility in vitro, determination of the change of molecular weight distribution of soluble proteins and peptides before and during enzymatic incubation might improve the understanding of both in vitro and in vivo digestion of proteins in feed ingredients.

The objective of the present study was to determine in vitro protein digestion kinetics of different protein sources. The in vitro protein digestion kinetics were described as the change in $\mathrm{N}$ solubility and in molecular weight distribution of the soluble protein and peptide fraction during in vitro simulation of gastric and intestinal protein digestion in pigs.

\section{MATERIALS AND METHODS}

\section{Experimental design}

Each protein source was incubated in triplicate with pepsin and pancreatin sequentially. Per protein source, values were averaged and expressed as mean \pm SEM.

\section{Protein sources and enzymes used for in vitro incubations}

The protein sources evaluated were five batches of soybean meals (SBMs) (four obtained from Nutreco, Boxmeer, the Netherlands; one as a commodity batch obtained via Research Diet Services, Wijk bij Duurstede, the Netherlands), and single batches of wheat gluten (WG), rapeseed meal (RSM), whey powder (WP) (all commodity batches obtained via Research Diet Services, Wijk bij Duurstede, the Netherlands), dried porcine plasma protein (DPP) (obtained from Darling Ingredients Inc., Irving, TX, USA), yellow meal worm larvae (MW) (obtained from Kreca, Ermelo, the Netherlands), and black soldier fly larvae (BSF) (obtained from the Laboratory of Entomology, Wageningen University, the Netherlands).

Porcine pepsin (2000 FIP U/g, Merck, Darmstadt, Germany), porcine pancreatin (P1750, Sigma-Aldrich, St. Louis, MO, USA) and porcine bile extract (B8631, Sigma-Aldrich, St. Louis, MO, USA) were used in the peptic and pancreatic incubations, respectively. 


\section{Chemical analysis}

All chemical analyses were performed according to standard laboratory methods. Protein sources were analysed for DM (method ISO 6496; ISO, 1999b), ash (method ISO 5984; ISO, 2002), acid-hydrolysed ether extract (method ISO 6492; ISO 1999a) and $\mathrm{N}$ by Kjedahl method (method ISO 5983-1; ISO, 2005). The $\mathrm{N}$ content of samples obtained during the sequential incubation with pepsin and pancreatin was determined using the Dumas method (method ISO 16634-1; ISO, 2008) and a Flash EA 1112 NC Analyzer (Thermo Fisher Scientific, Waltham, MA, USA).

In vitro incubations with pepsin and pancreatin

The protein sources were hydrolysed according to a two-step method described by Boisen and Fernández (1997) with modifications. All protein sources were ground using an ultracentrifugal mill with a $1 \mathrm{~mm}$ sieve (ZM200, Retsch $\mathrm{GmbH}$, Hann, Germany). For the simulation of protein digestion in the stomach, $1 \mathrm{~g}$ of sample was incubated in a $100 \mathrm{~mL}$ plastic centrifuge tube with a phosphate buffer $(25 \mathrm{~mL}, 0.1 \mathrm{M}, \mathrm{pH} 6.0)$ and an $\mathrm{HCl}$ solution (2 $\mathrm{mL}, 1 \mathrm{M}$ ). The $\mathrm{pH}$ was adjusted to 3.5 with $1 \mathrm{M} \mathrm{HCl}$ or $1 \mathrm{M} \mathrm{NaOH}$. Freshly prepared pepsin solution ( $1 \mathrm{~mL}, 10 \mathrm{~g} / \mathrm{L})$ was added and each centrifuge tube was covered with a plastic lid and placed in the heating chamber at $39{ }^{\circ} \mathrm{C}$ under constant magnetic stirring. The incubation times with pepsin were 0, 30, 60 and 90 min. Following the 90-min incubation with pepsin, the protein digestion in the small intestine was simulated by adding $10 \mathrm{~mL}$ phosphate buffer $(0.2 \mathrm{M}, \mathrm{pH} 6.8)$ and $3 \mathrm{~mL}, 1 \mathrm{M}, \mathrm{NaOH}$ to the samples and the $\mathrm{pH}$ was adjusted to 6.8 with $1 \mathrm{M} \mathrm{HCl}$ or $1 \mathrm{M} \mathrm{NaOH}$. Freshly prepared pancreatin solution $(1 \mathrm{~mL}, 100 \mathrm{~g} / \mathrm{L})$ and bile solution $(1 \mathrm{~mL}, 150 \mathrm{~g} / \mathrm{L})$ were added and the incubation with pancreatin was continued in the heating chamber at $39^{\circ} \mathrm{C}$ under constant magnetic stirring. The incubation times with pancreatin were 0 , 30, 60, 90, 120, 150, 180 and $210 \mathrm{~min}$. To correct for the $\mathrm{N}$ of the enzymes added, blanks (triplicates) without protein sources were analysed. The samples taken during the sequential incubation with pepsin and pancreatin and from blanks were cooled on ice for $10 \mathrm{~min}$ and then centrifuged (30 $\mathrm{min}, 20,000 \mathrm{~g}, 4^{\circ} \mathrm{C}$ ) to separate the insoluble protein fraction (IPF) and soluble fraction (SPF). After centrifugation, the supernatant containing the soluble fraction was transferred to a $50 \mathrm{~mL}$ volumetric flask and the flask was made up to $50 \mathrm{~mL}$ with de-mineralized water. One $\mathrm{mL}$ of soluble fraction was transferred to a $2 \mathrm{~mL}$ Eppendorf tube (Eppendorf AG, Hamburg, Germany) and $20 \%$ sulfosalicylic acid was added to the sample in a 1:1 (v/v) ratio. The sample was centrifuged (10 $\mathrm{min}, 12000 \mathrm{~g}, 4^{\circ} \mathrm{C}$ ) to separate the soluble high molecular weight 
(> $500 \mathrm{Da}$ ) peptides (HMW) and the soluble low molecular weight (< $500 \mathrm{Da}$ ) peptides (LMW) (Greenberg and Shipe, 1979). The IPF was freeze-dried and ground using an ultracentrifugal mill with a $1 \mathrm{~mm}$ sieve (ZM200, Retsch $\mathrm{GmbH}$, Hann, Germany) prior to chemical analysis.

\section{Size exclusion chromatography}

The molecular weight distribution of hydrolysates in the SPF was analysed using an ÄKTA micro system (GE Healthcare, Uppsala, Sweden) with a Superdex Peptide PC 3.2/30 column (GE Healthcare). The eluent used was a $10 \mathrm{mM}$ potassium phosphate buffer with $150 \mathrm{mM} \mathrm{NaCl}$ and $2 \%$ SDS. All samples were first boiled for 5 min to inactivate the enzymes and then diluted with the eluent in a 1:1 (v/v) ratio. Thereafter, samples were centrifuged (10 $\min , 20000 \mathrm{~g}, 20{ }^{\circ} \mathrm{C}$ ), and $50 \mu \mathrm{L}$ of the sample were injected onto the column. The absorbance was measured at $214 \mathrm{~nm}$. For the calibration curve, $\beta$-lactoglobulin (18,360 Da), aprotinin (6,512 Da), vitamin B12 (1,335 Da), glutathione (307 Da) and glycine (75 Da) were used. The chromatograms obtained were separated into molecular weight ranges of $>10 \mathrm{kDa}, 10-5 \mathrm{kDa}, 5-3 \mathrm{kDa}, 3-1 \mathrm{kDa}$ and $<1 \mathrm{kDa}$ by calculating the eluent volumes based on the calibration curve.

\section{Calculations and statistical analysis}

The $\mathrm{N}$ solubility was calculated by equation 1 :

$$
\text { N solubility }(\%)=\frac{N_{\text {sample }}-\left(N_{\text {ppe }}-N_{\text {banan }}\right)}{N_{\text {sample }}} \times 100 \%
$$

where $\mathrm{N}_{\text {sample }}(\mathrm{mg})$ is the amount of $\mathrm{N}$ in $1 \mathrm{~g}$ of protein source, $\mathrm{N}_{\mathrm{IPF}}(\mathrm{mg})$ is the amount of $\mathrm{N}$ in the IPF during the sequential incubation with pepsin and pancreatin, and $N_{\text {blank }}(\mathrm{mg}$ ) is the amount of $\mathrm{N}$ in the IPF of blank samples during the sequential incubation with pepsin and pancreatin.

The $\mathrm{N}$ present in LMW was calculated by equation 2:

Soluble low molecular weight peptides fraction $(\%)=\frac{N_{\text {umw }}-N_{\text {bank }}}{N_{\text {sample }}} \times 100 \%$

where $N_{\llcorner M w}(\mathrm{mg})$ is the amount of $\mathrm{N}$ in the LMW during the sequential incubation with pepsin and pancreatin, $\mathrm{N}_{\text {blank }}(\mathrm{mg})$ is the amount of $\mathrm{N}$ in the LMW of blank samples during the sequential incubation with pepsin and pancreatin, and $N_{\text {sample }}(\mathrm{mg})$ is the amount of $\mathrm{N}$ in $1 \mathrm{~g}$ of protein source. 
The kinetics of $\mathrm{N}$ solubilisation and the release of LMW for different protein sources during the incubations were described using an exponential equation (Ørskov and McDonald, 1979) (equation 3):

$$
\mathrm{D}_{\mathrm{t}}=\mathrm{D}_{0}+\Delta \mathrm{D} \times\left(1-\mathrm{e}^{-\mathrm{kt}}\right)
$$

where $D_{t}(\%)$ is the $N$ solubility or the $N$ present in LMW at incubation time $t$ (min), $\mathrm{D}_{0}(\%)$ is the $\mathrm{N}$ solubility or the $\mathrm{N}$ present in $\mathrm{LMW}$ at $0 \mathrm{~min}, \Delta \mathrm{D}(\%)$ is maximum $\mathrm{N}$ solubility or the $\mathrm{N}$ present in LMW (asymptote) corrected for $\mathrm{D}_{0}$, and $\mathrm{k}$ is the rate constant.

The kinetics of $\mathrm{N}$ solubilisation of MW during pepsin hydrolysis and the kinetics the release of LMW of MW during pancreatin hydrolysis were described using a linear equation (equation 4) as these data did not fit the exponential equation.

$$
D_{t}=D_{0}+k t
$$

where $D_{t}(\%)$ is the $N$ solubility or the $N$ present in LMW at incubation time $t$ (min), $\mathrm{D}_{0}(\%)$ is the $\mathrm{N}$ solubility or the $\mathrm{N}$ present in $\mathrm{LMW}$ at $0 \mathrm{~min}$, and $\mathrm{k}$ is the rate constant.

Data on $\mathrm{N}$ present in the IPF, HMW and LMW as percentage of total $\mathrm{N}$ during the sequential incubation with pepsin and pancreatin were analysed by analysis of variance using the GLM procedure of SAS (version 9.3, SAS Institute Inc., Cary, NC) with protein source, time and the interaction between protein source and time as fixed effects. All dependent variables were tested for normality and non-normal distributed data were log transformed. Probability levels of less than $5 \%$ were considered to be statistically significant, and levels between 5 to $10 \%$ were considered a trend.

\section{RESULTS}

\section{Chemical composition of protein source}

The analysed chemical composition of the protein sources is presented in Table 2.1. The SBMs had a mean crude protein content of $46.5 \pm 2.2 \%$ (standard deviation). The crude protein content of the other protein sources ranged from $24.9 \%$ for WP to $80.0 \%$ for DPP. 


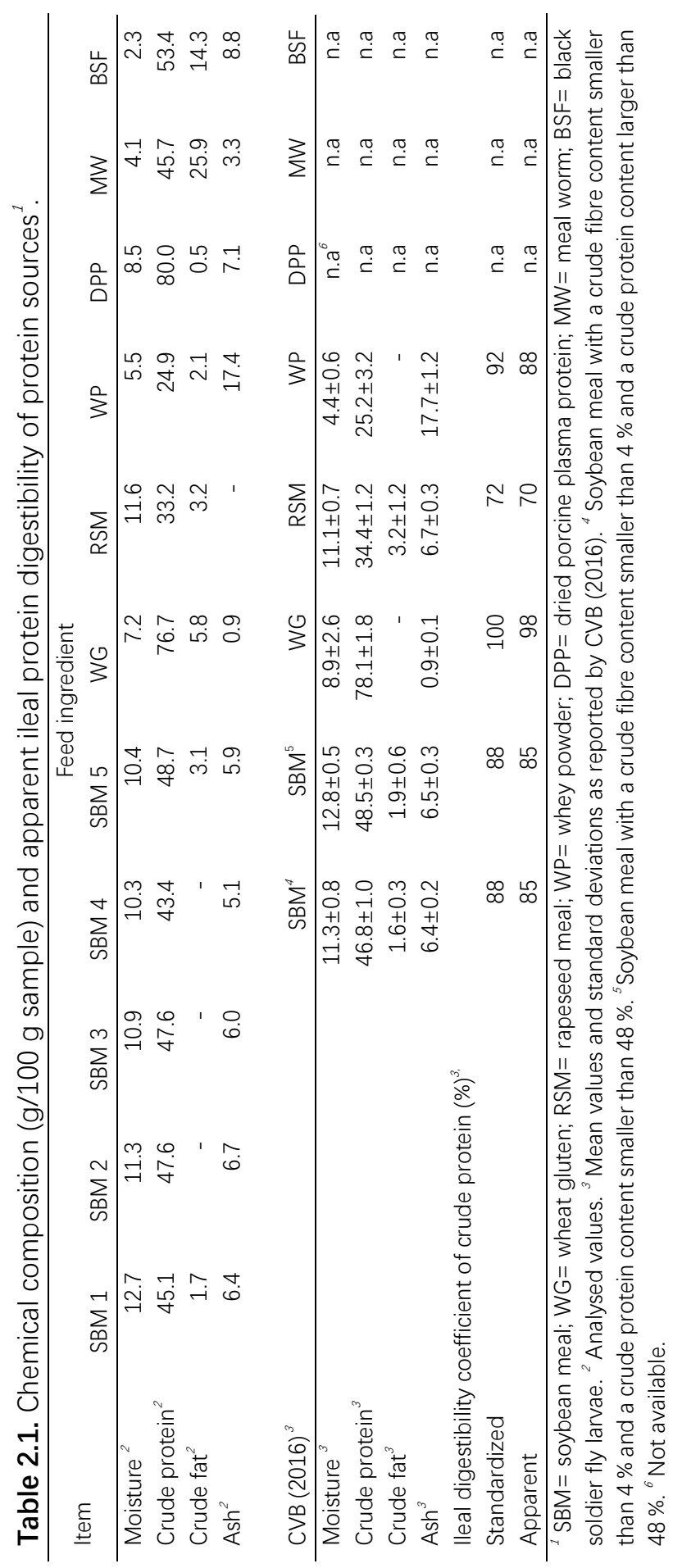


Separation of soluble nitrogen into high molecular weight fraction and low molecular weight fraction

Prior to the start of incubation with pepsin, the five batches of SBM showed a mean $\mathrm{N}$ solubility of $7 \pm 6 \%$. The soluble $N$ was only present in HMW (Table 2.2). Between 0 and 30 min of the incubation with pepsin, the $\mathrm{N}$ solubility of SBMs increased from an average of 7 to $18 \%$. At the end of incubation with pepsin (90 min), the SBMs showed a mean N solubility of $21 \pm 2 \%$, of which $10 \%$ was present in LMW and $11 \%$ in HMW. After the incubation with pepsin, $\mathrm{pH}$ of the incubation solutions was adjusted from 3.5 to 6.8. This change of $\mathrm{pH}$ resulted in an increased $\mathrm{N}$ solubility of SBMs from an average of 21 to $50 \%$, mainly related to an increased solubility of HMW (from an average of 11 to $39 \%$ ). During the incubation with pancreatin, the $\mathrm{N}$ solubility of SBMs increased from an average of 50 to $83 \%$ between 0 and $30 \mathrm{~min}$. At the end of incubation with pancreatin (210 min), SBMs showed a mean N solubility of $92 \pm 1 \%$, of which $38 \%$ was present in LMW and $54 \%$ in HMW.

For the other protein sources, prior to the start of incubation with pepsin, the $\mathrm{N}$ solubility ranged from $9 \%$ for WG to $95 \%$ for WP. For MW and BSF, 6 and $11 \%$ of total $\mathrm{N}$ was present in LMW, respectively. For the other protein sources, soluble $\mathrm{N}$ was only present in HMW (Figure 2.1). The N solubility of WG, RSM, MW and BSF increased during the sequential incubation with pepsin and pancreatin and was affected by the interaction between protein source and incubation time $(P<0.001)$ (Table 2.3). The $N$ solubility of these four protein sources ranged from $34 \%$ for RSM to $82 \%$ for WG at the end of incubation with pepsin, and from $79 \%$ for RSM to $98 \%$ for WG at the end of incubation with pancreatin. Similar to what was observed in SBMs, the changes in $\mathrm{N}$ solubility occurred mainly in the initial phase (between 0 to $30 \mathrm{~min}$ ) of both the incubation with pepsin and with pancreatin. In contrast, the N solubility for WP and DPP remained high with values 98 and $99 \%$, respectively, during the sequential incubation with pepsin and pancreatin. 


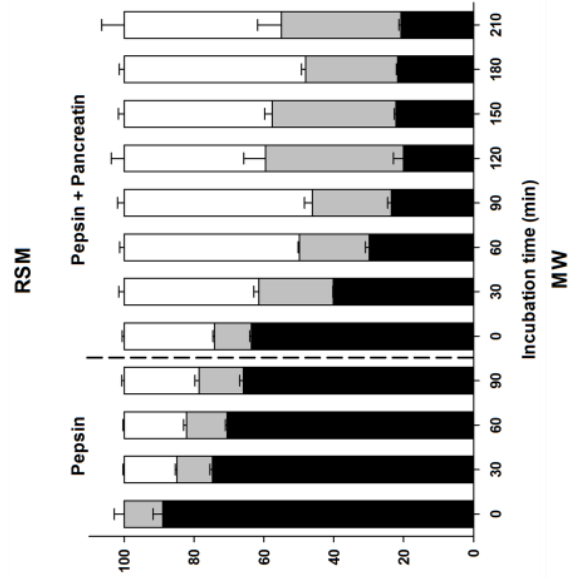

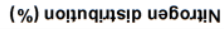

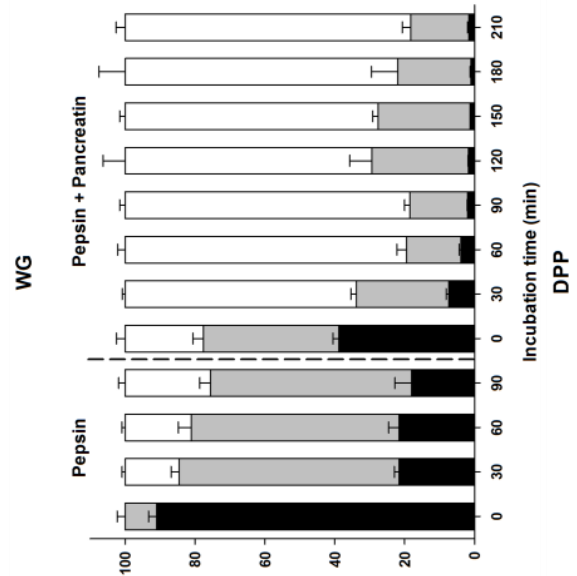

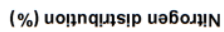

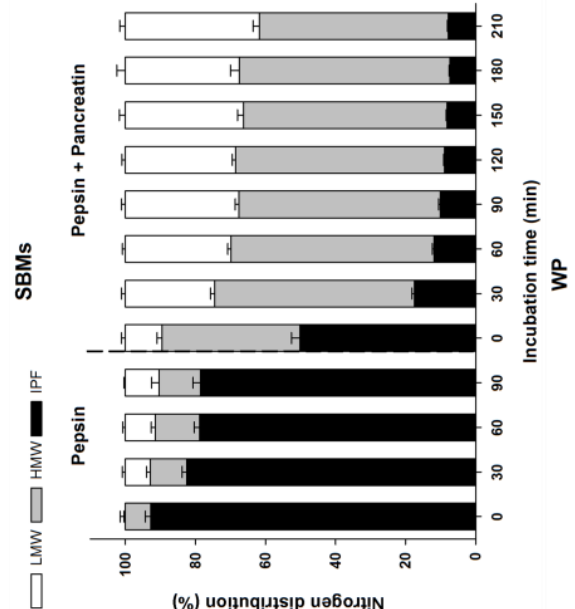

(\%) uo!̣nqu!ฺเ!p uอ6od!̣

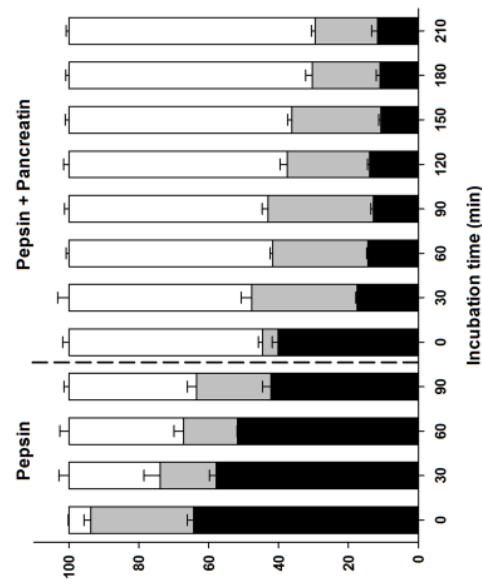

(\%) uo!̣nquns!p uə6od!n

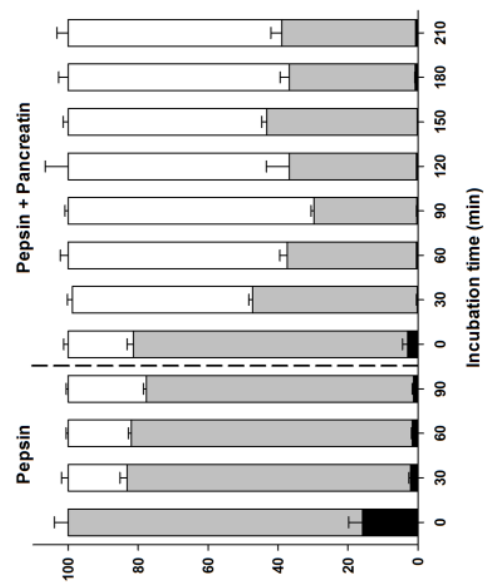

(\%) uopnnqus!p uə6อม!

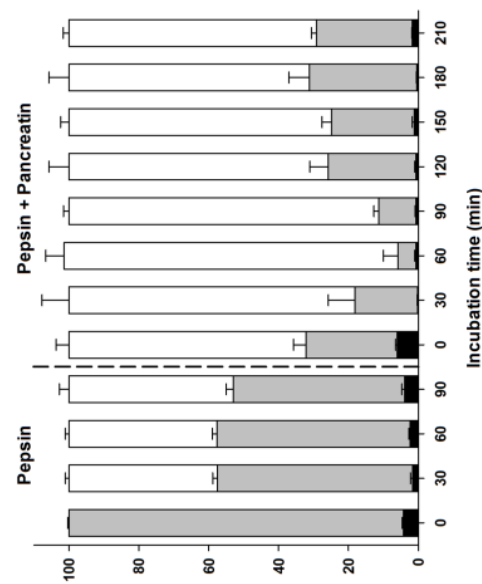

(\%) uo!̣nquมs!p uə601!n 


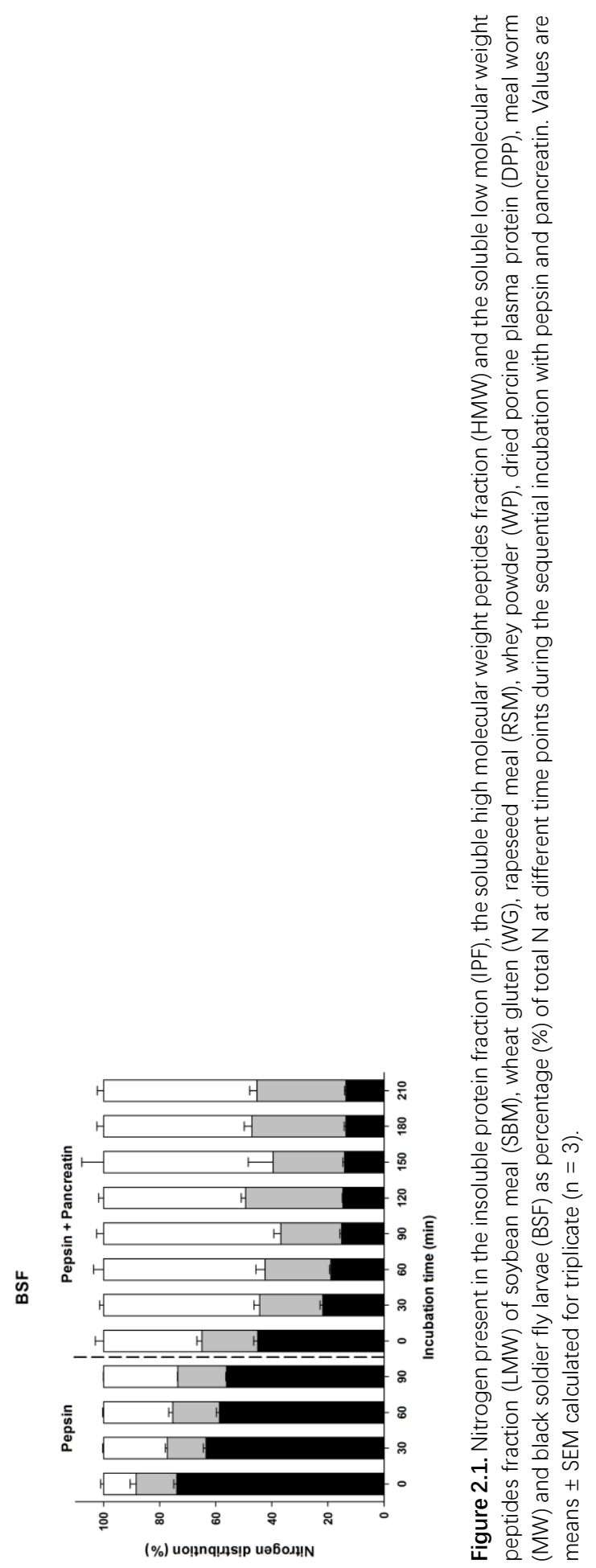




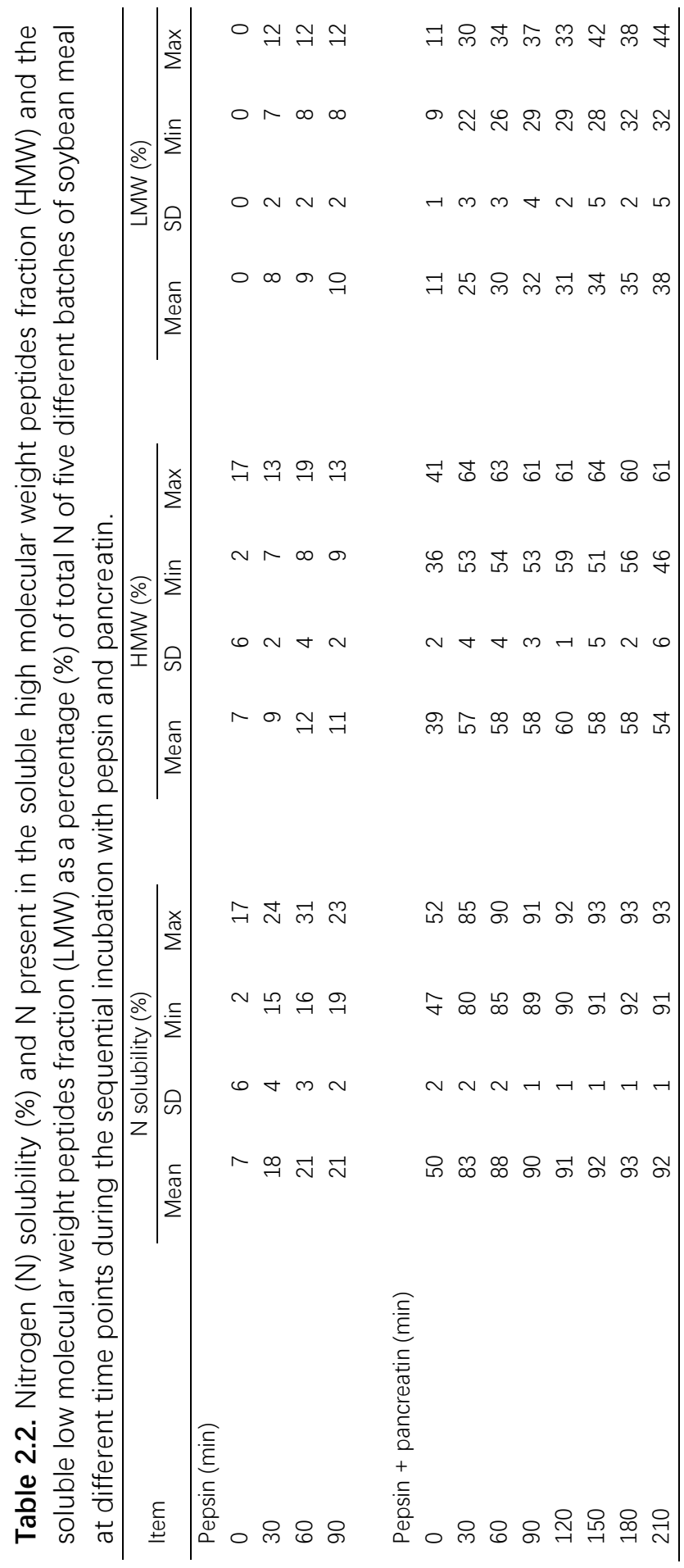


The $\mathrm{N}$ present in the HMW and LMW as percentage of total $\mathrm{N}$ during the sequential incubation with pepsin and pancreatin showed an interaction between protein source and time of incubation $(P<0.001)$ (Table 2.3). The differences in the percentage of $N$ present in the HMW and LMW were large among protein sources (Figure 2.1). At the end of incubation with pepsin, N present in LMW ranged from $21 \%$ for RSM to $44 \%$ for WP. Rape seed meal, MW and BSF showed a higher percentage of $N$ in the LMW compared to the HMW. At the end of incubation with pancreatin, N present in the LMW ranged from $45 \%$ for RSM to $82 \%$ for WG. All protein sources showed a higher percentage of $\mathrm{N}$ in the LMW compared to the HMW at the end of incubation with pancreatin with the exception of SBMs.

Table 2.3. Effect of protein source, incubation time and their interaction on the nitrogen present in the insoluble protein fraction (IPF), the soluble high molecular weight peptides fraction (HMW) and the soluble low molecular weight peptides fraction (LMW) as percentage of total $\mathrm{N}$ during the sequential incubation with pepsin and pancreatin.

\begin{tabular}{lrrrr}
\hline \multirow{2}{*}{ Fraction } & \multicolumn{4}{c}{ Pepsin } \\
\cline { 2 - 5 } & & \multicolumn{4}{c}{$P$-value } \\
\cline { 2 - 5 } & Pooled SEM & Protein source & Incubation time & Interaction \\
\hline IPF & 2.0 & $<0.001$ & $<0.001$ & $<0.001$ \\
HMW & 2.2 & $<0.001$ & $<0.001$ & $<0.001$ \\
LMW & 1.1 & $<0.001$ & $<0.001$ & $<0.001$ \\
\hline \multirow{4}{*}{ Fraction } & \multicolumn{4}{c}{ Pepsin + pancreatin } \\
\cline { 2 - 5 } & Pooled SEM & Protein source & Incubation time & Interaction \\
\hline IPF & 0.8 & $<0.001$ & $<0.001$ & $<0.001$ \\
HMW & 3.4 & $<0.001$ & $<0.001$ & $<0.001$ \\
LMW & 3.3 & $<0.001$ & $<0.001$ & $<0.001$ \\
\hline
\end{tabular}


Changes in molecular weight distribution of soluble proteins and peptides during in vitro digestion based on size exclusion chromatogram (SEC)

An increase of total absorbance at $214 \mathrm{~nm}$ was observed from the SEC chromatogram of SBMs during the sequential incubation with pepsin and pancreatin (Figure 2.2). During the incubation with pepsin, the amount of peptides with a molecular weight range of 5-10 kDa increased (Figure 2.3). During the incubation with pancreatin, the amount of peptides with a molecular weight range of 5-10 kDa decreased, whereas the amount of peptides with a molecular weight smaller than $1 \mathrm{kDa}$ increased.

Wheat gluten, RSM, MW and BSF behaved similar to the SBMs, with respect to total absorbance as well as the changes in molecular weight distribution of soluble proteins and peptide. In contrast, the total absorbance at $214 \mathrm{~nm}$ of WP and DPP stayed constant during the sequential incubation with pepsin and pancreatin. During the sequential incubation with pancreatin, the amount of peptides with a molecular weight range of 5-10 kDa decreased, whereas the percentage of peptides with a molecular weight range of $1-5 \mathrm{kDa}$ increased.

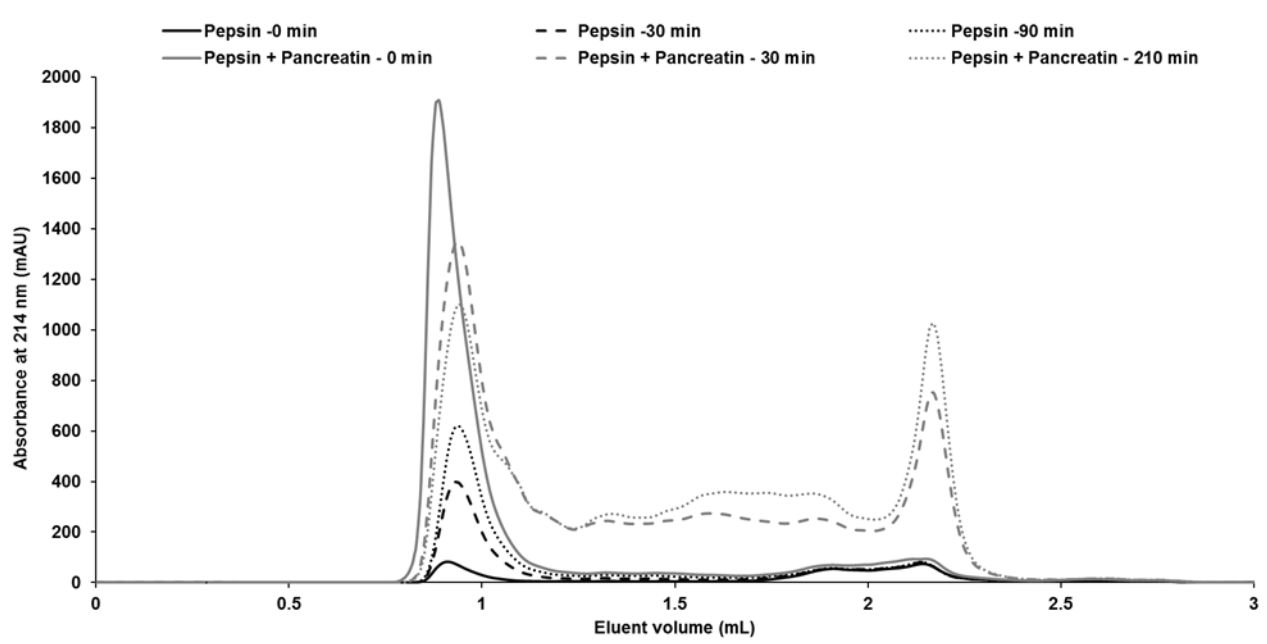

Figure 2.2. Size-exclusion chromatograms of soluble proteins and peptides of one batch of soybean meal at different time points during sequential incubation with pepsin and pancreatin. 
During the incubation with pepsin, SBMs had a mean $\mathrm{N}$ solubilisation rate of $0.042 \pm 0.007 \mathrm{~min}^{-1}$ with a mean maximum increase $(\Delta \mathrm{D})$ of $15 \pm 2 \%$ (Table 2.4). As for the kinetics of the release of low molecular weight peptides, SBMs had a mean rate of $0.065 \pm 0.011 \mathrm{~min}^{-1}$ with a mean maximum increase of $10 \pm 1 \%$. During the incubation with pancreatin, SBMs had a mean $\mathrm{N}$ solubilisation rate of $0.049 \pm 0.003 \mathrm{~min}^{-1}$ with a mean maximum increase of $42 \pm 1 \%$. As for the kinetics of the release of low molecular weight peptides, SBMs had a mean rate of $0.029 \pm 0.005 \mathrm{~min}^{-1}$ with a mean maximum increase of $24 \pm 1 \%$.

There were large differences between the kinetics of $\mathrm{N}$ solubilisation and the release of LMW for the different protein sources (Figure 2.4). During the incubation with pepsin, the $\mathrm{N}$ solubilisation rate ranged from $0.025 \mathrm{~min}^{-1}$ for BSF to $0.685 \mathrm{~min}^{-1}$ for WP, and the release rate of LMW ranged from $0.027 \mathrm{~min}^{-1}$ for WG to $0.093 \mathrm{~min}^{-1}$ for WP. During the incubation with pancreatin, the $\mathrm{N}$ solubilisation rate ranged from $0.027 \mathrm{~min}^{-1}$ for RSM to $0.343 \mathrm{~min}^{-1}$ for WP, and the release rate of low molecular weight peptides ranged from $0.046 \mathrm{~min}^{-1}$ for RSM to $0.385 \mathrm{~min}^{-1}$ for WP (Table 2.4). 

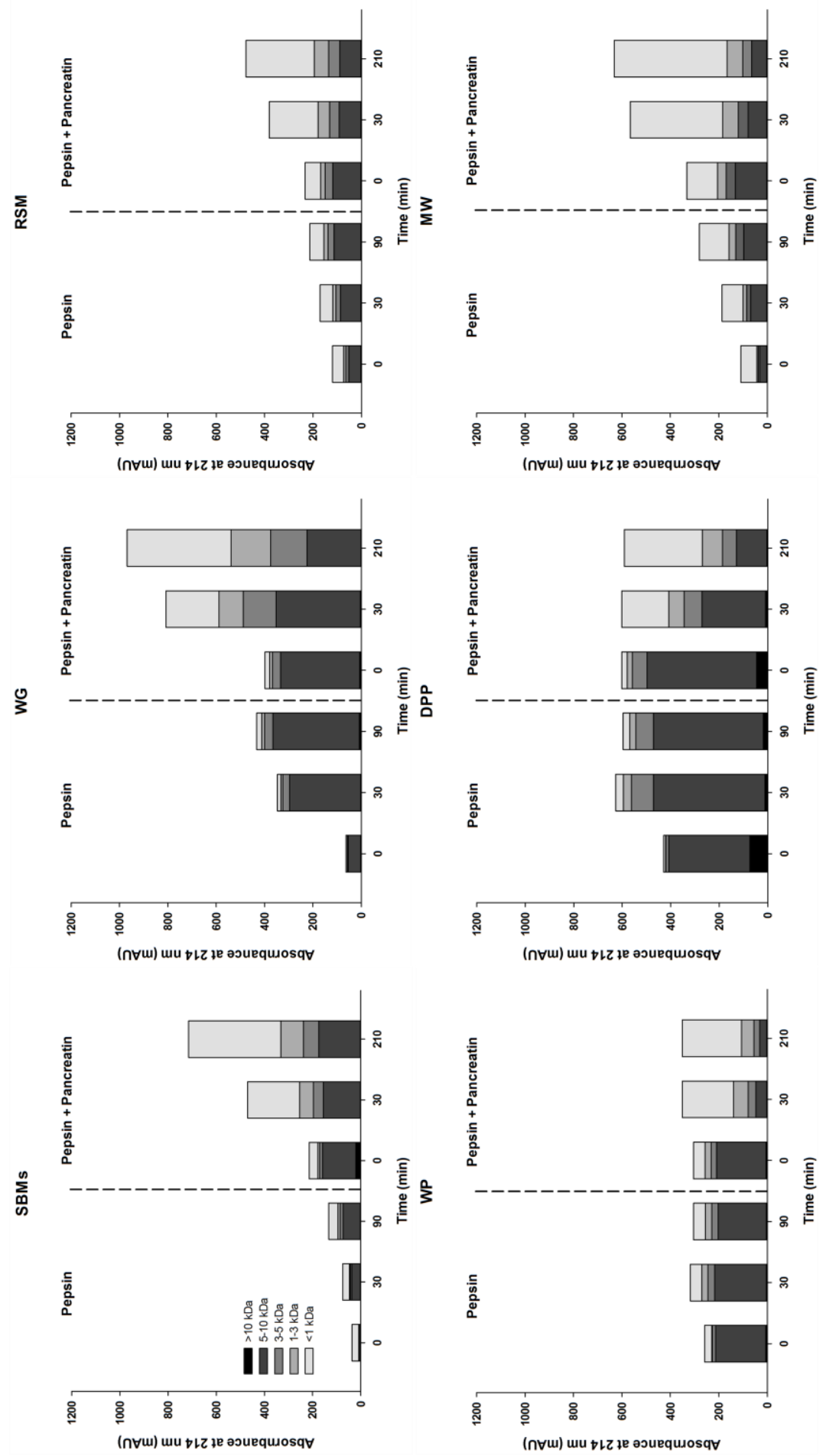


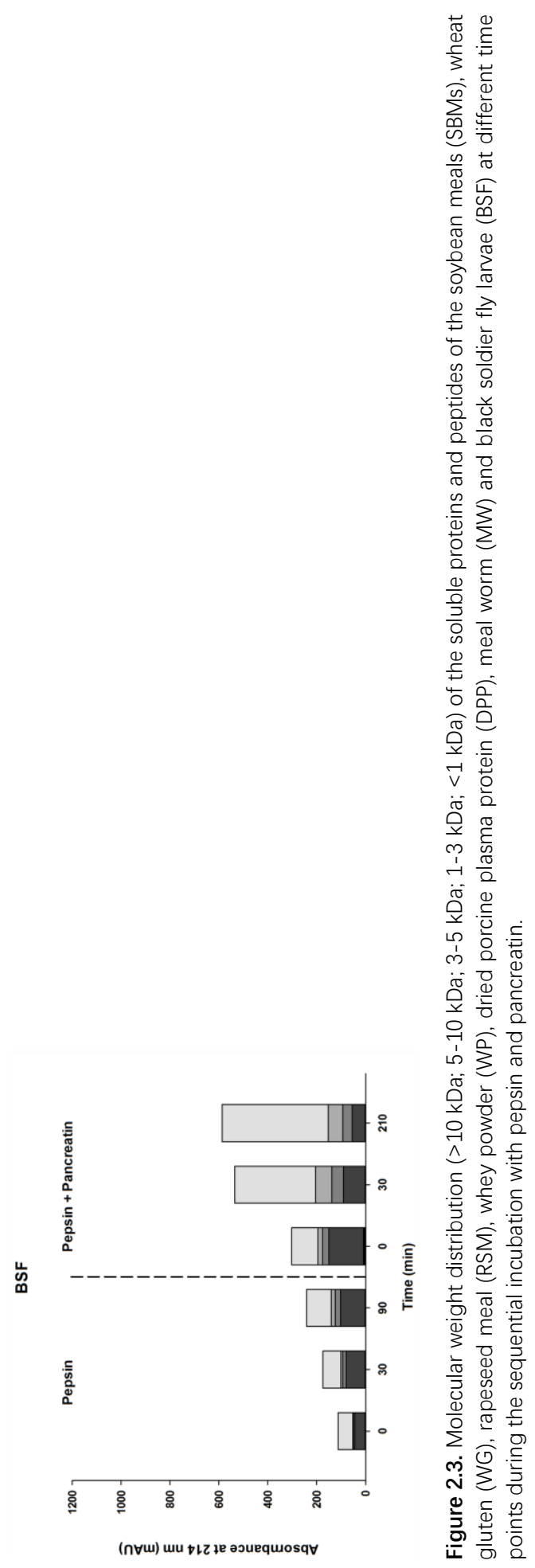


(A) N solubilisation
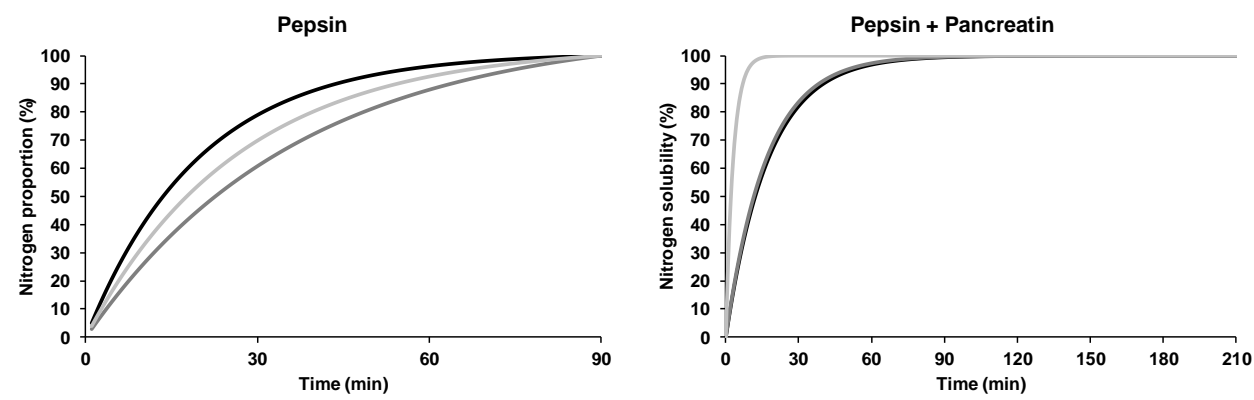

(B) Release of LMW
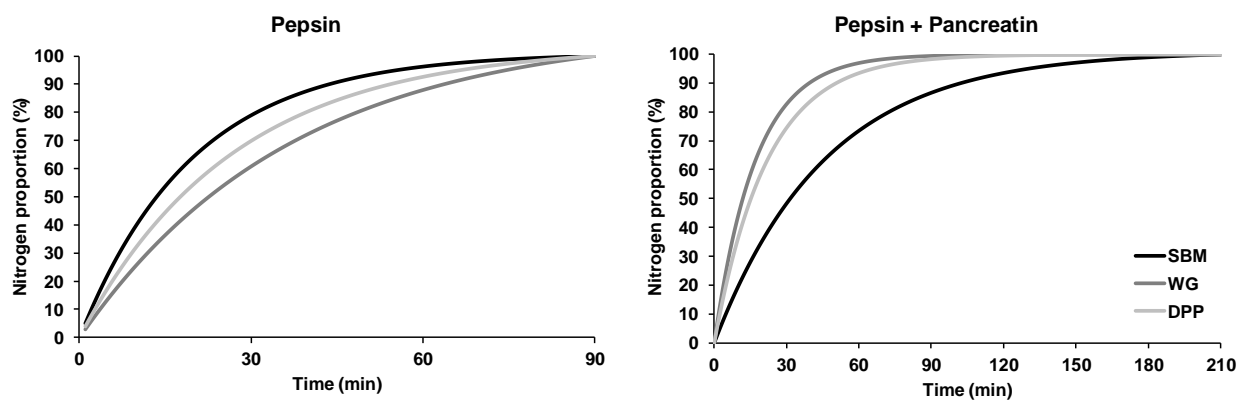

Figure 2.4. Rescaled kinetics curves (using $D_{0}$ as $0 \%$ and $D_{\max }$ as $100 \%$ ) of nitrogen (N) solubilisation (A) and the release of low molecular weight peptides (LMW) (B) of one batch of soybean meal (SBM), wheat gluten (WG) and dried porcine plasma protein (DPP) during sequential incubation with pepsin and pancreatin. 


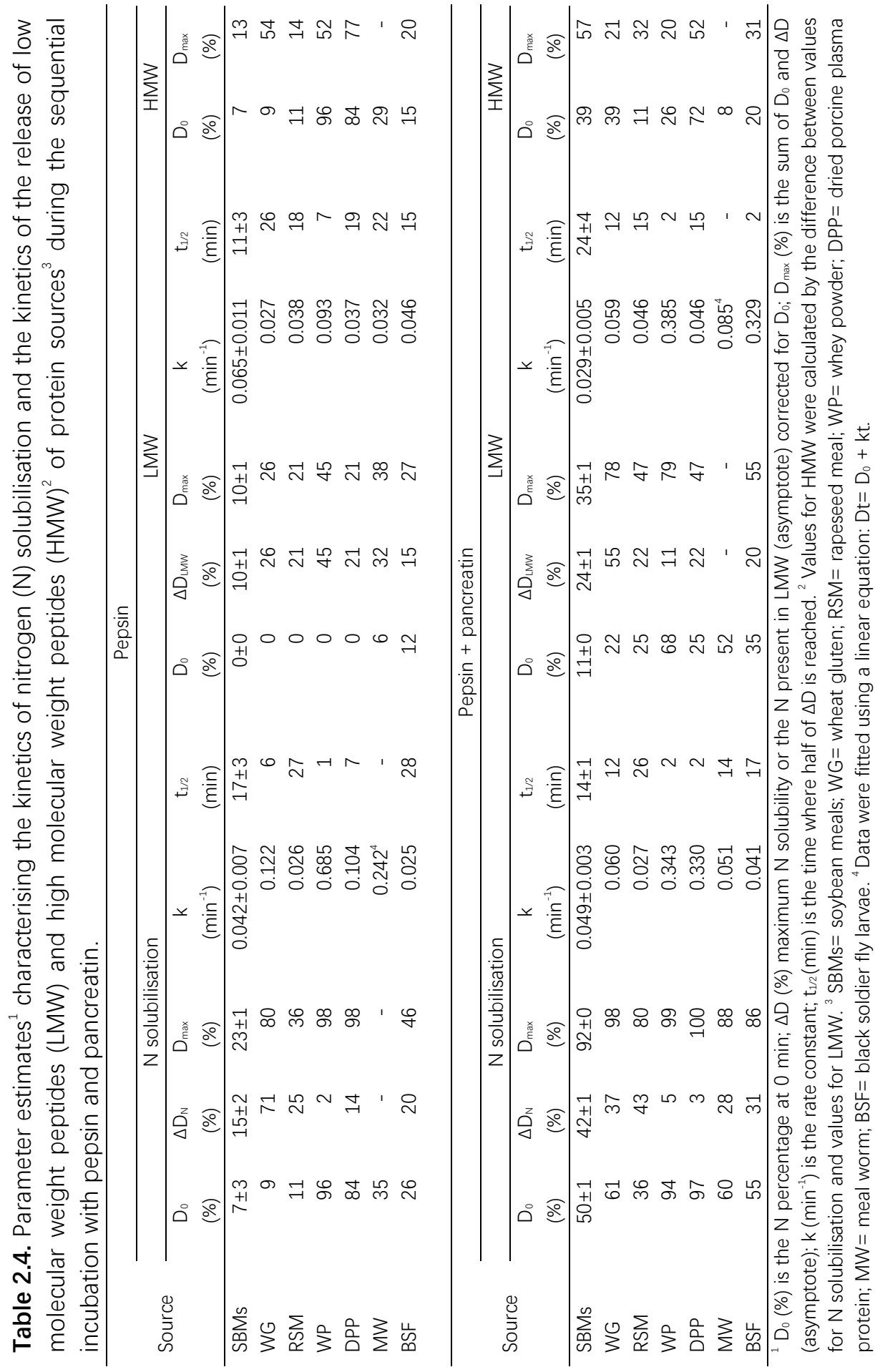




\section{DISCUSSION}

In the present study, in vitro protein digestion kinetics of protein sources differing in origin, chemical composition and in vivo protein digestibility was studied using a twostep in vitro method with sequential incubation with pepsin and pancreatin. Multiple batches of SBM as well as single batches of WG, RSM, WP, DPP, MW and BSF were evaluated. The chemical composition of the batches of SBMs, WG, RSM and WP was close to the tabulated values (CVB, 2016), indicating that the batches used in the current study were representative for these ingredients as protein sources in animal feeds with respective to the chemical composition.

In the present study, in vitro protein digestibility values are represented by the values for maximum $\mathrm{N}$ solubility after the incubation with pancreatin. Values for SBM, RSM, MW and BSF (92, 80, 88 and $86 \%$, respectively) are comparable to those reported in literature in which similar in vitro methods were applied (93, 84, 90 and 91 \%, respectively) (Cone and van der Poel, 1993; Boisen and Fernández, 1995; Bosch et al., 2014). The kinetics of $N$ solubilisation was established only for the potentially soluble fraction, corrected for the soluble fraction at the start of the in vitro incubations (Don). $\Delta D_{N}$ differed greatly among protein sources, ranging from 2 for WP to $71 \%$ for WG. During the sequential incubation with pepsin and pancreatin, WP showed a higher rate of $\mathrm{N}$ solubilisation than the other protein sources. The $\mathrm{N}$ solubility of WP, however, was already high prior to the start of enzymatic incubations, resulting in a low $\Delta D_{N}$ for WP ( 2 and $5 \%$ during the incubations with pepsin and pancreatin, respectively). A rate estimated based on a small $\Delta \mathrm{D}$ fraction provides limited information compared to a rate based on a large $\Delta \mathrm{D}$ fraction. The $\mathrm{N}$ solubilisation rates of WP should, therefore, be viewed with caution. In the present study, WG showed a greater rate of $\mathrm{N}$ solubilisation than SBM during the incubation with pepsin. This result is not in agreement with data from (Wilfart et al., 2008), who found no difference in the rate of $\mathrm{N}$ solubilisation for SBM and wheat during the incubation with pepsin.

The kinetics of the release of LMW was established only for the potentially releasable fraction corrected for the fraction already present at the start of the in vitro incubations (DoLmw). This fraction also differed largely among protein sources, ranging from 11 for WP to $55 \%$ for WG. Whey protein showed a faster release of LMW than other protein sources. Wheat gluten showed the slowest release during the incubation with pepsin and SBMs during the incubation with pancreatin. At the end of sequential incubation with pepsin and pancreatin, WG and WP showed the highest percentage of LMW in 
the soluble fraction and SBMs the lowest. Under in vivo conditions, the release of LMW is expected to be higher than measured in vitro. This relates to the action of brush border aminopeptidases, which are involved in the final step of protein digestion. The brush border aminopeptidases contribute to a substantial release of LMW (Silk et al., 1985; Picariello et al., 2015).

Luo et al. (2015) showed that the in vitro hydrolysis of whey protein using pepsin followed the "zipper" type of protein hydrolysis mechanism, meaning that proteins are hydrolysed into peptides with a very wide range of molecular weights during the various stages of the hydrolysis process (Adler-Nissen, 1976). Assuming the hydrolysis of protein sources using pepsin and pancreatin also follows the "zipper" type of protein hydrolysis mechanism, a substantial quantity of peptides with intermediate molecular weight were expected during the in vitro incubations in the present study. Such a substantial quantity of intermediate peptides, however, was not observed. Instead, a decrease of intact proteins and HMW and a concomitant and immediate increase of LMW were observed. These results suggest that intact proteins from the protein sources are hydrolysed in one sequence to low molecular weight peptides and free amino acids by the proteolytic action of pepsin and proteases in pancreatin.

It should be emphasized that in the present study, a high rate of $\mathrm{N}$ solubilisation did not correlate to a fast release of LMW for each of the protein sources evaluated. For instance, WG showed a high rate of $\mathrm{N}$ solubilisation but a slow release of LMW during the incubation with pepsin. Compared to the in vitro protein digestion kinetics based on $\mathrm{N}$ solubilisation, the in vitro protein digestion kinetics based on the release of LMW might be a better prediction of in vivo protein digestion kinetics. In vivo, dietary proteins need to be hydrolysed into free amino acids and di- and tri-peptides prior to absorption as these are the main forms of $\mathrm{N}$ that can be absorbed by enterocytes in the small intestine (Webb et al., 1992; Ganapathy et al., 2000). Therefore, a fast release of free amino acids and di- and tri-peptides from the protein sources results in a fast absorption in the GIT, thereby leading to a more rapid postprandial appearance of amino acids and peptides in blood after ingestion of a meal. There is limited published information available on the correlation between in vitro and in vivo protein digestion kinetics of feed ingredients for pigs. In contrast to protein digestion kinetics, starch digestion kinetics, both in vitro and in vivo, for pigs has been extensively studied. In pigs, portal glucose appearance is strongly related to in vitro release of glucose $\left(R^{2}=0.89\right)$ by starch digestion. Fast digestible starch, such as rice starch, showed a fast release of glucose in vitro and a rapid portal appearance of glucose in vivo. In contrast, 
slow digestible starch, such as pea starch, showed a slower release of glucose in vitro and a delayed portal appearance of glucose in vivo (van der Meulen et al., 1997; van Kempen et al., 2010). Similar to glucose as the end product of starch digestion, free amino acids and di- and tri-peptides are the end products of protein digestion. Thus, the kinetics of the release of LMW might better reflect in vivo protein digestion kinetics than the kinetics of $\mathrm{N}$ solubilisation. Digestion kinetics of protein can influence postprandial appearance of free amino acids and peptides in blood in time. Protein sources with a fast release of LMW during the sequential incubation with pepsin and pancreatin can be expected to be digested faster in vivo, resulting in an early appearance of amino acids and peptides in the blood after a meal. Information on protein digestion kinetics can be used to further develop the concept of nutrient (i.e. energy and protein) synchronisation, which could improve overall protein utilisation (van den Borne et al., 2007; Drew et al., 2012).

The differences in the extent and the kinetics of protein digestion among protein sources can be related to various factors. Pepsin, trypsin and chymotrypsin are specific enzymes, meaning they can only cleave certain peptide bonds. The number and accessibility of these cleavage sites for enzymes depend on the amino acid sequence of polypeptide chains and their conformation. For instance, rapeseed albumins showed a higher resistance to pepsin hydrolysis in vitro compared to rapeseed globulins (Malabat and Rabiller, 2001). This is likely due to the compact conformation of rapeseed albumins due to the presence of disulphide bonds (Schwenke et al., 1988). The accessibility of the cleavage sites for enzymes also depends on the physicochemical properties of the protein. A soluble form of casein (i.e. $\mathrm{Na}^{+}$-caseinate) was hydrolysed faster in vitro than native casein because soluble proteins have a better accessibility to enzymes than insoluble proteins (Tonheim et al., 2007). The non-protein constituents can interact with the proteins in the protein source. For instance, tannins present in legume seeds and phytate present in soybeans can bind to proteins. The bound proteins are not susceptible to enzymatic hydrolysis by digestive enzymes, leading to a reduced protein digestibility in pigs (Mangan, 1988; Selle et al., 2012). Thermal treatment is commonly involved in the processing of ingredients or complete diets for pigs to improve nutrient digestibility (Johnston et al., 1998) or to eliminate antinutritional factors (van der Poel, 1990). Severe thermal treatment, however, induces protein aggregation, resulting in a higher resistance to digestive enzymes (SánchezRivera et al., 2015). 


\section{CONCLUSION}

The present study showed substantial differences in in vitro protein digestion kinetics among protein sources, as measured via kinetics of $\mathrm{N}$ solubilisation and release of free amino acids and soluble low molecular weight peptides (LMW). The rate of release of LMW was not correlated to the rate of $\mathrm{N}$ solubilisation for each of the protein sources evaluated. Whey protein showed a fast rate of both $\mathrm{N}$ solubilisation and release of LMW. In contrast, wheat gluten and dried porcine plasma protein showed a fast rate of $\mathrm{N}$ solubilisation but a slow release of LMW. In vitro protein digestion kinetics as determined by the kinetics of release of LMW might be a preferred method for the prediction of in vivo protein digestion kinetics.

\section{ACKOWLEDGEMENTS}

The authors gratefully acknowledge the financial support from the Wageningen UR "IPOP Customized Nutrition" programme financed by Wageningen UR (Wageningen, the Netherlands), the Dutch Ministry of Economic Affairs, Agriculture \& Innovation (the Hague, the Netherlands), WIAS graduate school (Wageningen, the Netherlands); Nutreco (Boxmeer, the Netherlands) and Darling Ingredients International (Irving, TX, USA). 


\section{REFERENCES}

Adler-Nissen, J. 1976. Enzymic hydrolysis of proteins for increased solubility. J. Agric. Food Chem. 24:10901093.

Babinszky, L., J. M. van der Meer, H. Boer, and L. A. den Hartog. 1990. An in-vitro method for prediction of the digestible crude protein content in pig feeds. J. Sci. Food Agric. 50:173-178.

Boirie, Y., M. Dangin, P. Gachon, M. P. Vasson, J. L. Maubois, and B. Beaufrère. 1997. Slow and fast dietary proteins differently modulate postprandial protein accretion. Proc. Natl. Acad. Sci. 94:14930-14935.

Boisen, S., and J. A. Fernández. 1995. Prediction of the apparent ileal digestibility of protein and amino acids in feedstuffs and feed mixtures for pigs by in vitro analyses. Anim. Feed Sci. Technol. 51:29-43.

Bosch, G., S. Zhang, D. G. A. B. Oonincx, and W. H. Hendriks. 2014. Protein quality of insects as potential ingredients for dog and cat foods. J. Nutr. Sci. 3:29.

Cone, J. W., and A. F. B. van der Poel. 1993. Prediction of apparent heal protein digestibility in pigs with a two-step in-vitro method. J. Sci. Food Agric. 62:393-400.

CVB. 2016. Chemical compositions and nutritional values of feed ingredients. Centraal Veevoeder Bureau, Wageningen, the Netherlands.

Dangin, M., Y. Boirie, C. Garcia-Rodenas, P. Gachon, J. Fauquant, P. Callier, O. Ballèvre, and B. Beaufrère. 2001. The digestion rate of protein is an independent regulating factor of postprandial protein retention. Am. J. Physiol. Metab. 280:340-348.

Drew, M. D., T. C. Schafer, and R. T. Zijlstra. 2012. Glycemic index of starch affects nitrogen retention in grower pigs. J. Anim. Sci. 90:1233-1241.

Ganapathy, V., M. E. Ganapathy, and F. H. Leibach. 2000. Intestinal transport of peptides and amino acids. Curr. Top. Membr. 50:379-412.

ISO. 1999a. ISO 6492:1999. Animal feeding stuffs-Determination of fat content. International Organization for Standardization, Geneva, Switzerland.

ISO. 1999b. ISO 6496:1999. Animal feeding stuffs-Determination of moisture and other volatile matter content. International Organization for Standardization, Geneva, Switzerland.

ISO, 2002. ISO 5984:2002. Animal feeding stuffs-Determination of crude ash content. International Organization for Standardization, Geneva, Switzerland.

ISO. 2005. ISO 5983-1:2005. Animal feeding stuffs-Determination of $\mathrm{N}$ content and calculation of crude protein content-Part 1: Kjeldahl method. International Organization for Standardization, Geneva, Switzerland.

ISO. 2008. ISO 16634-1:2008. Food products-Determination of the total $\mathrm{N}$ content by combustion according to the Dumas principle and calculation of the crude protein content-Part 1: Oilseeds and animal feeding stuffs. International Organization for Standardization, Geneva, Switzerland.

Johnston, S. L., J. D. Hancock, R. H. Hines, K. C. Behnke, G. A. Kennedy, C. A. Maloney, S. L. Traylor, S. P. Sorrell, B. Goodband, and M. Tokach. 1998. Effects of expander conditioning of corn-and sorghum-based diets on pellet quality and performance in finishing pigs and lactating sows. In: Kansas State University Swine Day 1998. Report of Progress 819. pp. 213-220.

Luo, Q., R. M. Boom, and A. E. M. Janssen. 2015. Digestion of protein and protein gels in simulated gastric environment. LWT-Food Sci. Technol. 63:161-168.

Mahé, S., R. Benamouzig, C. Gaudichon, J. F. Huneau, I. de Cruz, J. Rautureau, and D. Tomé. 1995. Nitrogen movements in the upper jejunum lumen in humans fed low amounts of casein or beta-lactoglobulin. Gastroenterol Clin. Biol. 19:20-26.

Malabat, C., and C. Rabiller. 2001. Emulsifying and foaming properties of native and chemically modified peptides from the $2 \mathrm{~S}$ and $12 \mathrm{~S}$ proteins of rapeseed (Brassica napus L.). J. Am. Oil Chem. 78:235-242.

Mangan, J. L. 1988. Nutritional effects of tannins in animal feeds. Nutr. Res. Rev. 1:209-231.

NRC. 2012. Nutrient requirements of swine. Eleventh revised edition. National Academic Press, Washington, D.C., USA.

Ørskov, E. R., and I. McDonald. 1979. The estimation of protein degradability in the rumen from incubation measurements weighted according to rate of passage. J. Agric. Sci. 92:499-503. 
Picariello, G., B. Miralles, G. Mamone, L. Sánchez-Rivera, I. Recio, F. Addeo, and P. Ferranti. 2015. Role of intestinal brush border peptidases in the simulated digestion of milk proteins. Nutr. Food Res. 59:948956.

Sánchez-Rivera, L., O. Ménard, I. Recio, and D. Dupont. 2015. Peptide mapping during dynamic gastric digestion of heated and unheated skimmed milk powder. Food Res. Int. 77:132-139.

Schwenke, K. D., B. Drescher, D. Zirwer, and B. Raab. 1988. Structural studies on the native and chemically modified low molecular mass basic storage protein (Napin) from rapeseed (Brassica napus L.). Biochem. Physiol. Pflanz. 183:219-224.

Selle, P. H., A. J. Cowieson, N. P. Cowieson, and V. Ravindran. 2012. Protein-phytate interactions in pig and poultry nutrition: a reappraisal. Nutr. Res. Rev. 25:1-17.

Silk, D. B. A., G. K. Grimble, and R. G. Rees. 1985. Protein digestion and amino acid and peptide absorption. Proc. Nutr. Soc. 44:63-72.

Tonheim, S. K., A. Nordgreen, I. Høgøy, K. Hamre, and I. Rønnestad. 2007. In vitro digestibility of watersoluble and water-insoluble protein fractions of some common fish larval feeds and feed ingredients. Aquaculture 262:426-435.

van den Borne, J. J. G. C., J. W. Schrama, M. J. W. Heetkamp, M. W. A. Verstegen, and W. J. J. Gerrits. 2007. Synchronising the availability of amino acids and glucose increases protein retention in pigs. Animal 1:666-674.

van der Meulen, J., J. G. M. Bakker, B. Smits, and H. de Visser. 1997. Effect of source of starch on net portal flux of glucose, lactate, volatile fatty acids and amino acids in the pig. Br. J. Nutr. 78:533-544.

van der Poel, A. F. B. 1990. Effect of processing on antinutritional factors and protein nutritional value of dry beans (Phaseolus vulgaris L.): a review. Anim. Feed Sci. Technol. 29:179-208.

van Kempen, T. A. T. G., P. I. R. Regmi, J. J. Matte, and R. T. Zijlstra. 2010. In vitro starch digestion kinetics, corrected for estimated gastric emptying, predict portal glucose appearance in pigs. J. Nutr. 140:12271233.

Webb, K. E., J. C. Matthews, and D. B. DiRienzo. 1992. Peptide absorption: a review of current concepts and future perspectives. J. Anim. Sci. 70:3248-3257.

Wilfart, A., Y. Jaguelin-Peyraud, H. Simmins, J. Noblet, J. van Milgen, and L. Montagne. 2008. Kinetics of enzymatic digestion of feeds as estimated by a stepwise in vitro method. Anim. Feed Sci. Technol. 141:171-183. 
50 P $\mathrm{Pag}$ 
Chapter 3

Protein sources differ in digestion kinetics in the small intestine of growing pigs and affect postprandial appearance of amino acids in blood

H. Chen ${ }^{\star}$, P.A. Wierenga ${ }^{\dagger}$, W.H. Hendriks ${ }^{*}$, A.J.M. Jansman ${ }^{\ddagger}$

"Animal Nutrition Group, Wageningen University \& Research, The Netherlands

'Laboratory of Food Chemistry, Wageningen University \& Research, The Netherlands

${ }^{\ddagger}$ Wageningen Livestock Research, The Netherlands 


\section{ABSTRACT}

The aim of the present study was to determine the in vivo protein digestion kinetics up to the end of the small intestine (SI) of five protein sources (soybean meal (SBM), wheat gluten (WG), rapeseed meal (RSM), dried porcine plasma protein (DPP), and black soldier fly larvae (BSF)), and its influence on the postprandial appearance of amino acids (AAs) and peptides in systemic blood in growing pigs (body weight $35 \mathrm{~kg}$ ). Forty pigs were randomly allocated to one of the five experimental diets containing the respective protein sources as the only source of protein. Four pigs per experimental diet were fitted with an ear-vein catheter and blood samples were collected before and after a morning meal. At dissection, digesta samples from the stomach and the SI, divided into four segments of equal length, were quantitatively collected. Apparent digestibility (AD) of crude protein (CP), and retention time (RT) of the solid fraction of digesta along the stomach and the SI were determined to calculate protein digestion kinetics. The RT in the stomach and in the $1^{\text {st }}, 2^{\text {nd }}$, and $3^{\text {rd }}$ SI segment did not differ among diets ( $\left.P>0.05\right)$. The $A D_{\text {сP }}$ was affected by the diet in the $3^{\text {rd }}$ and $4^{\text {th }} \mathrm{SI}$ segment and over the total gastrointestinal tract $(P<0.001)$. The CP digestion rate ranged from $0.010 \mathrm{~min}^{-1}$ for the RSM diet to $0.035 \mathrm{~min}^{-1}$ for the DPP diet. The postprandial concentration of AAs and peptides in systemic blood after a meal showed an interaction between time and diet $(P<0.001)$. The rate of increase of the concentration of AAs and peptides ranged from $0.0046 \mathrm{~min}^{-1}$ for the SBM diet to $0.0330 \mathrm{~min}^{-1}$ for the RSM diet. Over all diets, the increase of the postprandial concentration of AAs and peptides in systemic blood plasma after a meal was positively correlated with the amount of apparent digested protein up to the end of the small intestine $(r=0.73 ; P<0.001)$. In conclusion, WG and DPP can be regarded as fast digestible protein sources while SBM, RSM and BSF as more slowly digestible protein sources in growing pigs. 


\section{INTRODUCTION}

Currently pig diets are formulated taking into account the requirement of ileal digestible essential amino acids (AAs) of the animal, which only accounts for the total quantity of dietary essential AAs that is apparently absorbed in the gastrointestinal tract (GIT) up to the end of the ileum (NRC, 2012, CVB, 2016). In addition to ileal digestibility of protein and AAs, growing attention is given to the kinetics of protein digestion along the GIT since it provides information on the timing of release and absorption of AAs along the GIT after ingestion of a meal, e.g. in broilers (Liu and Selle, 2015). Information on the kinetics of protein digestion in pigs is scarce.

Based on the timing and the extent of postprandial increase of plasma AAs and peptides, protein sources can be categorised into fast and slowly digestible proteins (Boirie et al., 1997; Bos et al., 2003; Tang et al., 2009). Fast digestible proteins, which induce a pronounced but transient postprandial increase of plasma AAs and peptides, stimulate protein synthesis but at the same time might increase AA oxidation. In contrast, slowly digestible proteins, which induce a small but prolonged postprandial increase of AAs and peptides in plasma, inhibit body protein degradation and, therefore, can increase overall protein retention (Boirie et al., 1997; Dangin et al., 2001). Utilization of AAs and peptides in the post absorptive metabolism can be influenced by the kinetics of protein digestion relative to the digestion kinetics of energy providing nutrients in the diet such as starch. The simultaneous availability of AAs and glucose as energy source in blood increased body protein retention in pigs, resulting in a higher post absorptive utilization of absorbed AAs and peptides (van den Borne et al., 2007; Drew et al., 2012). Information on protein digestion kinetics as affected by protein sources can be used to further develop the concept of synchronising the supply of energy and protein, which could improve protein retention and overall protein utilisation efficiency in pigs.

The overall kinetics of dietary protein digestion is related to three aspects: 1) the passage rate of digesta along the GIT, 2) the hydrolysis rate of dietary proteins, and 3) the absorption rate of AAs and peptides by the intestinal mucosa. The passage rate of digesta along the GIT depends on the feeding pattern (i.e. feeding frequency and meal quantity) and the physicochemical properties (e.g. solubility, viscosity, water binding capacity) of digesta. A large volume of a meal (Hunt and Stubbs, 1975), a high solubility of digesta (Low, 1979) and an increase in dietary fibre content (Wilfart et al., 2007) decrease the passage rate of digesta along the GIT. The hydrolysis rate of dietary 
proteins is affected by protein conformation (Malabat and Rabiller, 2001), protein solubility (Tonheim et al., 2007), and by the interaction between proteins and nonprotein constituents in protein sources (Selle et al., 2012). The AA and peptide transport capacity across the intestinal mucosa was shown to be regulated by the luminal concentration of AAs and peptides (Stevens, 1992).

In humans and pigs, the postprandial increase of AAs in blood was found to be more rapid and pronounced for proteins with a high gastric passage rate (e.g. whey protein soy protein isolate) than for proteins with a delayed gastric emptying (e.g. casein) (Boirie et al., 1997; Tang et al., 2009). In pigs, soy protein concentrate showed a more rapid portal appearance of AAs than a mixture of untoasted and toasted soybean meal after meal ingestion. The difference might be due to a higher trypsin inhibitor activity in the diet with a mixture of untoasted and toasted soybean meal, resulting in a lower rate of hydrolysis of the dietary proteins (Jansman et al., 1997). It was demonstrated in a study with humans that protein hydrolysates show a faster and greater postprandial increase of plasma AAs than their non-hydrolysed equivalents. This might be due to that protein hydrolysates only require limited additional hydrolysis before being able to be absorbed in the small intestine (SI) (Morifuji et al., 2010).

The objectives of the present study were: 1) to determine the in vivo protein digestion kinetics up to the end of the SI in pigs of common and alternative protein sources used as feed ingredient, and 2) to evaluate the effect of protein digestion kinetics on the postprandial appearance of AAs and peptides in systemic blood. Protein digestion kinetics was studied by determining digesta retention time, protein digestibility and molecular weight distribution of proteins and peptides in digesta along the $\mathrm{SI}$ of growing pigs. It was hypothesized that: 1) highly digestible protein sources are digested faster than less digestible sources in the SI of pigs, and 2) protein sources with a fast digestion kinetics (i.e. fast gastric emptying, fast hydrolysis and/or absorption) induce a more rapid and pronounced postprandial appearance of amino acids and peptides in systemic blood of pigs. 


\section{MATERIALS AND METHODS}

\section{Protein sources and experimental diets}

The protein sources evaluated were soybean meal (SBM), wheat gluten (WG), rapeseed meal (RSM) (all commodity batches obtained via Research Diet Services, Wijk bij Duurstede, the Netherlands), dried porcine plasma protein (DPP) (obtained from Darling Ingredients Inc., Irving, TX, USA), and black soldier fly larvae meal (BSF) (obtained from Protix, Dongen, the Netherlands). All five experimental diets were formulated to be isoproteineous (CP, $160 \mathrm{~g} / \mathrm{kg}$ as-fed basis). Free AAs were added so the diets met at least $65 \%$ of the requirement of the first limiting amino acids of pigs (CVB, 2008). For BSF, information on the AA profile and ileal AA digestibility was obtained from literature (Veldkamp et al., 2012; Bosch et al., 2014). The amount of additional free AAs ranged from $0 \mathrm{~g} / \mathrm{kg}$ diet (as-fed basis) for RSM diet to $6.3 \mathrm{~g} / \mathrm{kg}$ diet (as-fed basis) for WG diet. In addition, a protein-free diet was formulated. Titanium dioxide $\left(\mathrm{TiO}_{2}\right)$ was included in all the diets as an indigestible maker at $2.5 \mathrm{~g} / \mathrm{kg}$ diet (as fed basis). All diets were produced by Research Diet Services (Wijk bij Duurstede, the Netherlands). The ingredient composition of the six experimental diets is presented in Table 3.1.

\section{Design, animals and housing}

This study was approved by the Animal Care and Use Committee of Wageningen University \& Research (Wageningen, the Netherlands). A total of 43 growing pigs (boars) (Topigs $20 \times$ Tempo from van Beek, Lelystad, the Netherlands) with an average initial body weight of $34.9 \pm 3.4 \mathrm{~kg}$ on the day of arrival were used. Forty out of 43 pigs were blocked on litter (eight blocks, five pigs per block) and pigs within a block were randomly allocated to one of the five experimental diets $(n=8)$. The remaining three pigs were allocated to the protein-free diet. Twenty pigs, four pigs per experimental diet excluding protein-free diet, were fitted with an ear-vein catheter at day 13, 14 and 15. Pigs were housed individually in metabolic cages $(1.3 \times 1.3 \mathrm{~m}$ or $2.0 \times 1.0 \mathrm{~m})$ with a tender foot floor in one large temperature controlled room. The ambient temperature was kept at $24{ }^{\circ} \mathrm{C}$ on day 1 and 2 , at $23^{\circ} \mathrm{C}$ on day 3 , and constant at $22^{\circ} \mathrm{C}$ from day 4 onwards. From day 1 to 27, the lights were turned on between $5.30 \mathrm{~h}$ till $19.00 \mathrm{~h}$. From day 28 to 30 , the lights were turned on between $2.30 \mathrm{~h}$ till $19.00 \mathrm{~h}$. 
Table 3.1. Composition of experimental diets ( $\mathrm{g} / \mathrm{kg}$, as-fed basis).

\begin{tabular}{|c|c|c|c|c|c|c|}
\hline \multirow[b]{2}{*}{ Ingredients } & \multicolumn{6}{|c|}{ Diets containing the various protein source ${ }^{1}$} \\
\hline & SBM & WG & RSM & DPP & BSF & $\mathrm{PF}$ \\
\hline Soybean meal & 342.7 & - & - & - & - & - \\
\hline Wheat gluten & - & 194.7 & - & - & - & - \\
\hline Rapeseed meal & - & - & 489.6 & - & - & - \\
\hline Dried porcine plasma protein & - & - & - & 196.0 & - & - \\
\hline Insect protein meal & - & - & - & - & 305.0 & 0.0 \\
\hline Maize starch & 376.2 & 527.9 & 258.0 & 521.4 & 451.0 & 712.8 \\
\hline Sucrose & 100.0 & 100.0 & 100.0 & 100.0 & 100.0 & 100.0 \\
\hline Dextrose & 50.0 & 50.0 & 50.0 & 50.0 & 50.0 & 50.0 \\
\hline Arbocel & 50.0 & 50.0 & 50.0 & 50.0 & 50.0 & 50.0 \\
\hline Soy oil & 43.3 & 17.6 & 30.0 & 32.6 & 6.4 & 30.0 \\
\hline Mineral and vitamin premix ${ }^{2}$ & 5.0 & 5.0 & 5.0 & 5.0 & 5.0 & 5.0 \\
\hline Limestone & 14.4 & 15.9 & 5.1 & 15.7 & 0.0 & 16.3 \\
\hline Salt & 4.1 & 2.0 & 4.0 & - & - & 2.0 \\
\hline Potassium chloride & - & - & - & - & 4.8 & 2.9 \\
\hline Monocalcium phosphate & 10.1 & 13.6 & 4.6 & 14.2 & 11.7 & 15.5 \\
\hline Potassium carbonate & 0.0 & 10.6 & 0.0 & 11.2 & 5.0 & 8.4 \\
\hline Sodium bicarbonate & 1.4 & 3.9 & 1.2 & - & 6.7 & 4.6 \\
\hline L-Lysine HCL & - & 5.8 & - & - & - & - \\
\hline DL-Methionine & 0.3 & - & - & 1.4 & 1.3 & - \\
\hline L-Threonine & - & 0.5 & - & - & - & - \\
\hline L-Tryptophan & - & - & - & - & 0.6 & - \\
\hline $\mathrm{TiO}_{2}$ & 2.5 & 2.5 & 2.5 & 2.5 & 2.5 & 2.5 \\
\hline \multicolumn{7}{|l|}{ Calculated nutrient composition } \\
\hline $\mathrm{NE}, \mathrm{MJ} / \mathrm{kg}$ & 10.7 & 10.7 & 9.2 & 10.7 & 10.7 & 11.2 \\
\hline Calcium & 8.2 & 8.2 & 7.0 & 8.2 & 11.8 & 8.5 \\
\hline Available phosphorus & 2.8 & 2.8 & 2.4 & 2.8 & 2.8 & 2.9 \\
\hline Sodium & 2.0 & 2.0 & 2.0 & 4.7 & 2.0 & 2.0 \\
\hline Digestible Lys & 8.7 & 7.0 & 6.2 & 12.5 & 9.0 & 0.0 \\
\hline Digestible Met + Cys & 4.2 & 5.7 & 5.2 & 7.2 & 4.2 & 0.0 \\
\hline Digestible Thr & 5.1 & 4.1 & 4.6 & 7.3 & 5.0 & 0.0 \\
\hline Digestible Trp & 1.8 & 1.3 & 1.4 & 2.1 & 1.3 & 0.0 \\
\hline
\end{tabular}

${ }^{1} \mathrm{SBM}=$ soybean meal; $\mathrm{WG}=$ wheat gluten; $\mathrm{RSM}=$ rapeseed meal; $\mathrm{DPP}=$ dried porcine plasma protein; $\mathrm{BSF}=$ black soldier fly larvae; $\mathrm{PF}=$ protein free. ${ }^{2}$ The mineral and vitamin premix supplied per kilogram of diet: Vitamin A, 7,000 IU; Vitamin D3, 1,700 IU; vitamin E, $20 \mathrm{lU}$; vitamin K3, $1.5 \mathrm{mg}$; vitamin B1, $1.5 \mathrm{mg}$; vitamin B2, $4 \mathrm{mg}$; pantothenic acid, $11 \mathrm{mg}$; niacin, $18 \mathrm{mg}$; vitamin B12, $18 \mu \mathrm{g}$; folic acid, $1 \mathrm{mg}$; vitamin B6, $1 \mathrm{mg}$; choline chloride, $100 \mathrm{mg} ; \mathrm{Fe}, 75 \mathrm{mg}$, as $\mathrm{FeSO}_{4} ; \mathrm{Cu}, 10 \mathrm{mg}$, as $\mathrm{CuSO}_{4} \cdot \mathrm{H}_{2} \mathrm{O} ; \mathrm{Zn}, 65 \mathrm{mg}$, as $\mathrm{ZnSO}_{4} ; \mathrm{Mn}, 30 \mathrm{mg}$, as $\mathrm{MnO}$; $\mathrm{Co}, 0.15 \mathrm{mg}$, as $\mathrm{CoCO}_{3} ;$ I, $0.75 \mathrm{mg}$, as $\mathrm{Kl}$; $\mathrm{Se}, 0.3 \mathrm{mg}$, as $\mathrm{Na}_{2} \mathrm{SeO}_{3}$; anti-oxidant, $50 \mathrm{mg}$. 


\section{Feeding}

From day 1 to 6, starting with $100 \%$ of a commercial diet, pigs were gradually fed increasing amounts of the experimental diets from day 7 onwards, from which point pigs were fed only the experimental diets. The experimental diets were provided in a mash form and mixed with water at a ratio of $1: 2$ (feed : water, w/w basis). Additional water consumption was limited to $0.3 \mathrm{~L}$ which was provided after each feeding. The feeding level was 2.5 times NE requirement for maintenance (293 kJ NE/kg BW ${ }^{0.75}$ ). During day 7 to 26 , the feed allowance was divided into two equal amounts, fed at 8.00 h and 16.00 h. During day 27 to 30, feed allowance was divided into 6 equal amounts with feeding starting at $5.30 \mathrm{~h}$ in the morning at intervals of three hours. On dissection days, all pigs were fed at least three of their six daily portions 2, 4 and 6 hours prior to dissection, starting at $8.30 \mathrm{~h}$ in the morning and finishing at $16.30 \mathrm{~h}$ in the afternoon. Pigs that were dissected in the afternoon received up to three additional portions of feed in the morning.

The three pigs fed the protein-free diet received the SBM diet from day 1 to 21 in two equal portions at $8.00 \mathrm{~h}$ and $16.00 \mathrm{~h}$. These pigs were gradually adapted to the proteinfree diet from day 22 to 24, and were completely fed the protein-free diet from day 25 to 27 . During day 25 to 27 , the daily feed allowance was divided into six equal portions, provided from $5.30 \mathrm{~h}$ in the morning at $3 \mathrm{~h}$ intervals.

\section{Sample collection and dissection procedure}

From day 14 to 16 , blood samples ( $1 \mathrm{~mL}$ per time point) were collected at 1 and $0.5 \mathrm{~h}$ before and $0.5,1,1.5,2,3,4,6$, and $8 \mathrm{~h}$ after the morning meal ingestion via the earvein catheter fitted one day before the blood collection. Blood samples were collected in tubes containing lithium-heparin and immediately centrifuged at $3000 \mathrm{~g}$ for $10 \mathrm{~min}$ at $4{ }^{\circ} \mathrm{C}$. Supernatants were stored at $-80^{\circ} \mathrm{C}$ for further analysis on the total plasma $\mathrm{AA}$ and peptide concentration. Faeces were collected using a faeces collection bag system (Wageningen UR Livestock Research, The Netherlands) attached to the rear end of the pigs from day 21 to 23. The collection bags were emptied each day and the faeces for four days collection were pooled per pig and freeze-dried for nitrogen analysis to calculate faecal digestibility of crude protein (CP). At the dissection days, pigs were anesthetised by injecting pentobarbitone in the jugular vein, followed by exsanguination through the carotid artery. The pigs were placed on their right lateral side and the body cavity was opened before the GIT from the stomach to the anus was carefully removed. The SI was carefully placed horizontally on the table without 
disturbing the digesta and separated from the stomach and the large intestine. The SI was then dissected from the mesentery and divided into four segments of equal length $\left(1^{\text {st }}, 2^{\text {nd }}, 3^{\text {rd }}\right.$ and $4^{\text {th }} \mathrm{SI}$ segment, starting from the stomach to the large intestine $)$. Throughout the entire dissection, care was taken to prevent the movement of digesta. The $1^{\text {st }} \mathrm{SI}$ segment comprised the entire duodenum and approximately the proximal quarter of the jejunum. The $2^{\text {nd }}$ and $3^{\text {rd }}$ SI segment comprised only the jejunum. The $4^{\text {th }}$ SI segment comprised approximately the distal quarter of the jejunum and the entire ileum. Digesta samples from the stomach and four segments of the SI were quantitatively collected by gentle stripping. The collected digesta samples were freezedried for nitrogen and titanium analysis to calculate digestibility of CP and retention time of the solid fraction of digesta along the GIT.

\section{Chemical analysis}

All chemical analyses were performed according to standard laboratory methods. The experimental diets were analysed for dry matter (DM) (method ISO 6496; ISO, 1999a), ash (method ISO 5984; ISO, 2002), acid-hydrolysed ether extract (method ISO 6492; ISO 1999b), starch (method ISO 15914; ISO, 2004), total sugars as reducing sugars (van Vuuren et al., 1993) and nitrogen by the Kjedahl method (method ISO 5983-1; ISO, 2005a). The protein sources were analysed for AA composition (method ISO 13903; ISO, 2005b). The nitrogen content of digesta and faecal samples was determined using the Dumas method (method ISO 16634-1; ISO, 2008) using a Flash EA 1112 NC Analyzer (Thermo Fisher Scientific, Waltham, MA, USA). The experimental diet, digesta and faecal samples were analysed for Ti content (Myers et al., 2004). Amino acids and peptides concentration in the plasma samples was determined using the ninhydrin method (Lee and Takahashi, 1966). In short, plasma samples were first deproteinized with $8 \%$ sulphosalicylic acid and then incubated with ninhydrin for $1 \mathrm{~h}$ at $100{ }^{\circ} \mathrm{C}$. The amino groups in the plasma samples reacted with ninhydrin and the purple colour was measured at $570 \mathrm{~nm}$ using an UV-visible light spectrophotometer (Thermo Fisher Scientific, Waltham, MA, USA). The total concentration of AAs and peptides in the plasma samples was calculated using a calibration curve using leucine.

\section{Size exclusion chromatography}

The molecular weight distribution of proteins and peptides in digesta samples was analysed using an ÄKTA micro system (GE Healthcare, Uppsala, Sweden) with a Superdex Peptide PC 3.2/30 column (GE Healthcare). The eluent used was a $10 \mathrm{mM}$ potassium phosphate buffer with $150 \mathrm{mM} \mathrm{NaCl}$ and $2 \%$ SDS. Freeze-dried digesta 
samples ( $20 \mathrm{mg}$ ) were weighed and solubilised in a $2 \%$ SDS solution with $100 \mathrm{mM}$ dithiothreitol. The samples were heated $\left(100{ }^{\circ} \mathrm{C}\right)$ for $30 \mathrm{~min}$ and then centrifuged (10 min, $\left.20,000 \mathrm{~g}, 20^{\circ} \mathrm{C}\right)$. The supernatants were diluted with the eluent in a $1: 1$ (v/v) ratio. Samples were then centrifuged, and $50 \mu \mathrm{L}$ of the supernatant was injected on the column. The absorbance was measured at $214 \mathrm{~nm}$ and corrected for the signals from the SDS solution and dithiothreitol solution in the chromatograms. For the calibration curve, $\beta$-lactoglobulin (18,360 Da), vitamin B12 (1,335 Da), glutathione (307 Da) and glycine-proline-glycine (229 Da), phenylalanine (165 Da) and alanine (89 Da) were used. The chromatograms obtained were separated into molecular weight ranges of $>10 \mathrm{kDa}$, 10-5 kDa, 5-3 kDa, 3-1 kDa and <1 kDa by calculating the eluent volumes based on the calibration curve. The mass-based extinction coefficient ( $\mathrm{mAU} / \mathrm{mg}$ ) was calculated by dividing the absorbance measured at $214 \mathrm{~nm}$ by the protein content of the samples.

\section{Calculations and statistical analysis}

The area under the curve (AUC) (mmole $\cdot \min / \mathrm{L})$ of the postprandial plasma AAs and peptides curve was calculated using the trapezoidal method. The postprandial curve was described by a one-compartment pharmacokinetic model, from which a kincrease (increase rate) and a kelimination (elimination rate) were calculated.

Apparent digestibility (AD) of DM and CP was calculated by equation 1 :

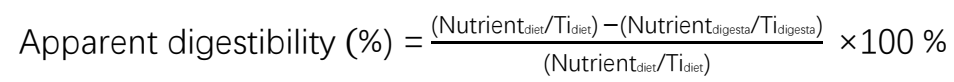

where Nutrient diet and Nutrient digesta $(\%)$ are the nutrient (DM or CP) content in the experimental diets (as-fed basis) and in the freeze-dried digesta samples, respectively, and $\mathrm{Ti}_{\text {diet }}$ and $\mathrm{Ti}_{\text {digesta }}(\%)$ are the $\mathrm{Ti}$ content in the same samples of experimental diets and digesta, respectively.

Retention time (RT) of the solid fraction of digesta in the stomach and four segments of the SI was calculated by equation 2 :

$$
\text { Retention time }(\mathrm{min})=\frac{1440 \times \mathrm{Tidigesta}_{\mathrm{a}} \times \mathrm{W}_{\text {digesta }}}{\mathrm{Fl}_{2 \text { 24 }} \times \mathrm{Ti}_{\text {dier }}}
$$

where $\mathrm{Ti}_{\text {digesta }}(\%)$ is the Ti content in the freeze-dried digesta samples, $\mathrm{W}_{\text {digesta }}(\mathrm{g})$ is the weight of freeze-dried digesta samples from the stomach or four segments of the SI, $\mathrm{Fl}_{24 \mathrm{~h}}(\mathrm{~g})$ is the feed intake over $24 \mathrm{~h}$ before sampling, Tidiet (\%) is the Ti content in the experimental diets (as-fed basis), and the factor 1440 is used to convert time from days to minutes. 
The nutrient digestion kinetics of different protein sources were calculated by relating the apparent digestibility coefficient for DM and CP at each segment of the SI with the sum of RT up to that segment. The curve was fitted using a first order reaction rate equation (equation 3):

$$
D_{t}=D_{\max }\left(1-e^{-k t}\right)
$$

where $D_{t}(\%)$ is the digestibility coefficient of DM or CP at time $t(\min ), D_{\max }(\%)$ is the potentially digestible DM or CP (\%) (asymptote), $\mathrm{k}$ is the rate constant. The equation was fitted using the MODEL procedure of SAS (version 9.3, SAS Institute Inc., Cary, NC) and the parameter estimates and the approximate standard error of the estimates were modelled.

The RT, $A D_{\text {dm }}$ and $A D_{\text {CP }}$ in each segment of the $S I$, and the AUC at each of the various time points were analysed by analysis of variance using the GLM procedure of SAS with protein source as a fixed effect. The postprandial concentration of AAs and peptides in plasma was analysed using the MIXED procedure with protein source, time and the interaction between protein source and time as fixed effects and pig as a random effect. The residuals of the dependent variables were tested for normality and non-normal distributed data were log transformed. Correlation between AUC and digestible proteins was analysed using the CORR procedure of SAS. Probability levels of less than $5 \%$ were considered to be statistically significant, and levels between 5 to $10 \%$ were considered a trend.

\section{RESULTS}

One pig from the DPP diet died during the installation of the ear-vein catheter and was replaced by one of the other four remaining pigs within the group. The other pigs remained healthy throughout the experiment.

\section{Chemical composition of experimental diets}

The CP content of the experimental diets containing the various protein sources ranged from $17.2 \%$ for the BSF diet to $18.3 \%$ for the SBM diet (DM basis) (Table 3.2). The WG and DPP diets had higher starch contents (50.1 and $74.2 \%$, respectively) and lower fat contents (2.1 and $2.2 \%$, respectively) than the other diets. 
Table 3.2. Analysed chemical composition of the experimental diets and the protein sources (\%, dry matter basis).

\begin{tabular}{|c|c|c|c|c|c|c|}
\hline & \multicolumn{6}{|c|}{ Diets containing the various protein source ${ }^{1}$} \\
\hline & SBM & WG & RSM & DPP & BSF & $\mathrm{PF}$ \\
\hline Dry matter (\% as-fed) & 90.4 & 90.4 & 91.1 & 91.2 & 91.9 & 89.6 \\
\hline Ash & 5.8 & 4.9 & 5.7 & 6.2 & 5.2 & 5.3 \\
\hline Crude protein & 18.3 & 17.3 & 17.9 & 17.3 & 17.2 & 0.3 \\
\hline Crude fat & 3.4 & 2.1 & 5.3 & 2.2 & 4.9 & 1.8 \\
\hline Starch & 32.8 & 50.1 & 25.9 & 47.2 & 41.9 & 63.0 \\
\hline \multirow[t]{2}{*}{ Sugar } & 19.4 & 16.9 & 21.9 & 17.8 & 16.3 & 17.8 \\
\hline & \multicolumn{6}{|c|}{ Protein source $^{1}$} \\
\hline Dry matter (\% as-fed) & 88.7 & 92.4 & 89.8 & 92.0 & 95.1 & \\
\hline Ash & 7.3 & 1.0 & 8.0 & 7.6 & 8.7 & \\
\hline Crude protein & 52.9 & 86.8 & 36.3 & 88.4 & 56.1 & \\
\hline $\begin{array}{l}\text { Crude fat } \\
\text { Indispensable AA }\end{array}$ & 1.7 & 5.0 & 3.9 & 1.6 & 11.8 & \\
\hline $\mathrm{His}$ & 1.5 & 1.8 & 1.1 & 3.0 & 1.6 & \\
\hline Ile & 2.5 & 3.1 & 1.5 & 3.4 & 2.0 & \\
\hline Leu & 4.1 & 5.7 & 2.6 & 8.4 & 3.2 & \\
\hline Lys & 3.2 & 1.3 & 1.9 & 7.3 & 2.6 & \\
\hline Met & 0.7 & 1.3 & 0.7 & 0.7 & 0.8 & \\
\hline Phe & 2.8 & 4.3 & 1.5 & 5.3 & 4.0 & \\
\hline Thr & 2.1 & 2.1 & 1.7 & 5.1 & 1.9 & \\
\hline Trp & 0.6 & 0.7 & 0.5 & 1.5 & 0.7 & \\
\hline Val & 2.6 & 3.3 & 2.0 & 5.8 & 2.9 & \\
\hline \multicolumn{7}{|l|}{ Dispensable AA } \\
\hline Ala & 2.4 & 2.2 & 1.6 & 4.7 & 3.3 & \\
\hline Arg & 3.4 & 2.5 & 1.9 & 4.4 & 1.9 & \\
\hline Asx & 6.0 & 2.5 & 2.7 & 8.3 & 4.1 & \\
\hline Cys & 0.7 & 1.5 & 0.8 & 2.7 & 0.4 & \\
\hline Glx & 9.5 & 29.4 & 6.1 & 12.1 & 4.4 & \\
\hline Gly & 2.3 & 2.7 & 1.9 & 3.1 & 2.4 & \\
\hline Pro & 2.7 & 10.4 & 2.3 & 5.5 & 2.6 & \\
\hline Ser & 2.6 & 3.6 & 1.6 & 4.9 & 1.9 & \\
\hline Tyr & 2.0 & 3.0 & 1.3 & 4.5 & 3.2 & \\
\hline
\end{tabular}

${ }^{1} \mathrm{SBM}=$ soybean meal; $\mathrm{WG}=$ wheat gluten; $\mathrm{RSM}=$ rapeseed meal; $\mathrm{DPP}=$ dried porcine plasma protein; $\mathrm{BSF}=$ black soldier fly larvae; $\mathrm{PF}=$ protein free. 


\section{Digestion kinetics of dry matter and crude protein along the SI}

The retention time (RT) of the solid fraction of digesta differed among the GIT segments $(P<0.001)$ (Table 3.3). The RT in the stomach did not differ among the diets $(P>0.05)$ with an average of $128 \pm 41 \mathrm{~min}$. The RT increased along the SI for all diets. The averaged RT from all diets in the $1^{\text {st }}, 2^{\text {nd }}, 3^{\text {rd }}$ and $4^{\text {th }}$ SI segment was, $10 \pm 13,36 \pm 25$, $63 \pm 37$, and $181 \pm 72 \mathrm{~min}$, respectively, with an estimated mean RT over the entire SI of $282 \pm 89 \mathrm{~min}$. The RT in the $1^{\text {st }}, 2^{\text {nd }}$, and $3^{\text {rd }} \mathrm{SI}$ segment did not differ among the diets $(P>0.05)$. The RT in the $4^{\text {th }} \mathrm{Sl}$ segment was higher for the WG diet than for the SBM, RSM and BSF diets $(P<0.05)$.

The $A D_{D M}$ and $A D_{C P}$ increased along the $\mathrm{SI}$ for all diets $(P<0.001)$. The $A D_{D M}$ did not differ among the diets in the $1^{\text {st }}$ and $2^{\text {nd }} \mathrm{Sl}$ segment $(P>0.05)$. The $A D_{\text {口M }}$ was affected by the diet in the $3^{\text {rd }}$ and $4^{\text {th }} \mathrm{SI}$ segment and over the total GIT $(P<0.001)$. In the $4^{\text {th }} \mathrm{SI}$ segment and consequently over the total GIT, the $A D_{D M}$ of $W G$ and PM diets was highest and for RSM diet lowest. The DPP diet tended to have a higher $A D_{\mathrm{cp}}$ in the $1^{\text {st }}$ and $2^{\text {nd }}$ $\mathrm{SI}$ segment than the RSM diet ( $P=0.09$ and 0.07 , respectively). The $\mathrm{AD}_{\mathrm{cp}}$ was affected by the diet in the $3^{\text {rd }}$ and $4^{\text {th }} \mathrm{SI}$ segment and over the total GIT $(P<0.001)$. In the $4^{\text {th }} \mathrm{SI}$ segment and over the total GIT, the WG diet showed the highest and the RSM diet the lowest $A D_{\text {cp. }}$.

The $A D_{\text {ом }}$ and $A D_{\text {ср }}$ at each $S$ l segment was related to the sum of the RT of digesta in that segment to determine the digestion rate of each diet. Large differences in DM and $\mathrm{CP}$ digestion rate were observed among diets (Table 3.3). The DM digestion rate ranged from $0.0128 \mathrm{~min}^{-1}$ for the WG diet to $0.0377 \mathrm{~min}^{-1}$ for the DPP diet. The CP digestion rate ranged from $0.0109 \mathrm{~min}^{-1}$ for the RSM diet to $0.0354 \mathrm{~min}^{-1}$ for the DPP diet. 


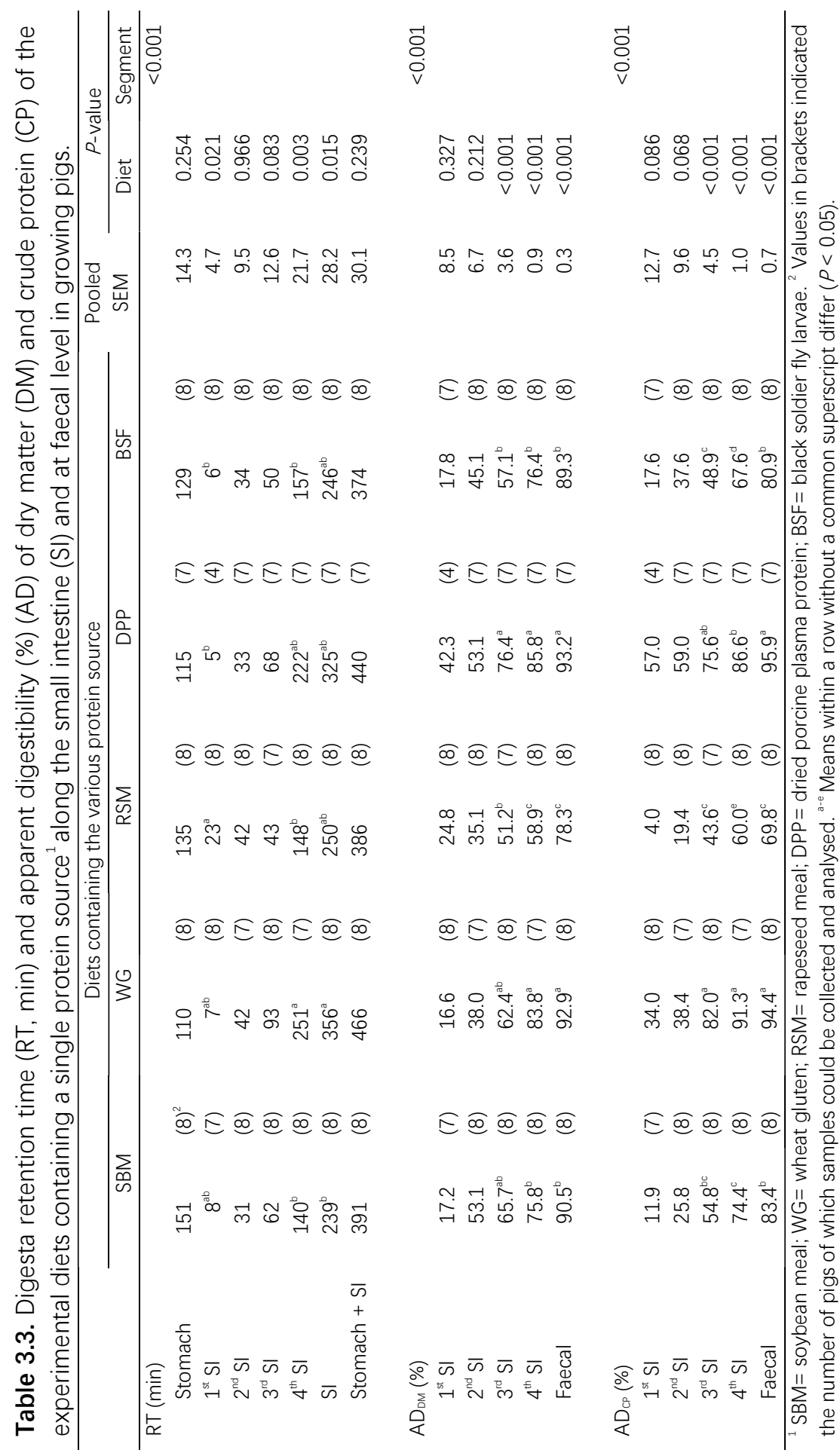




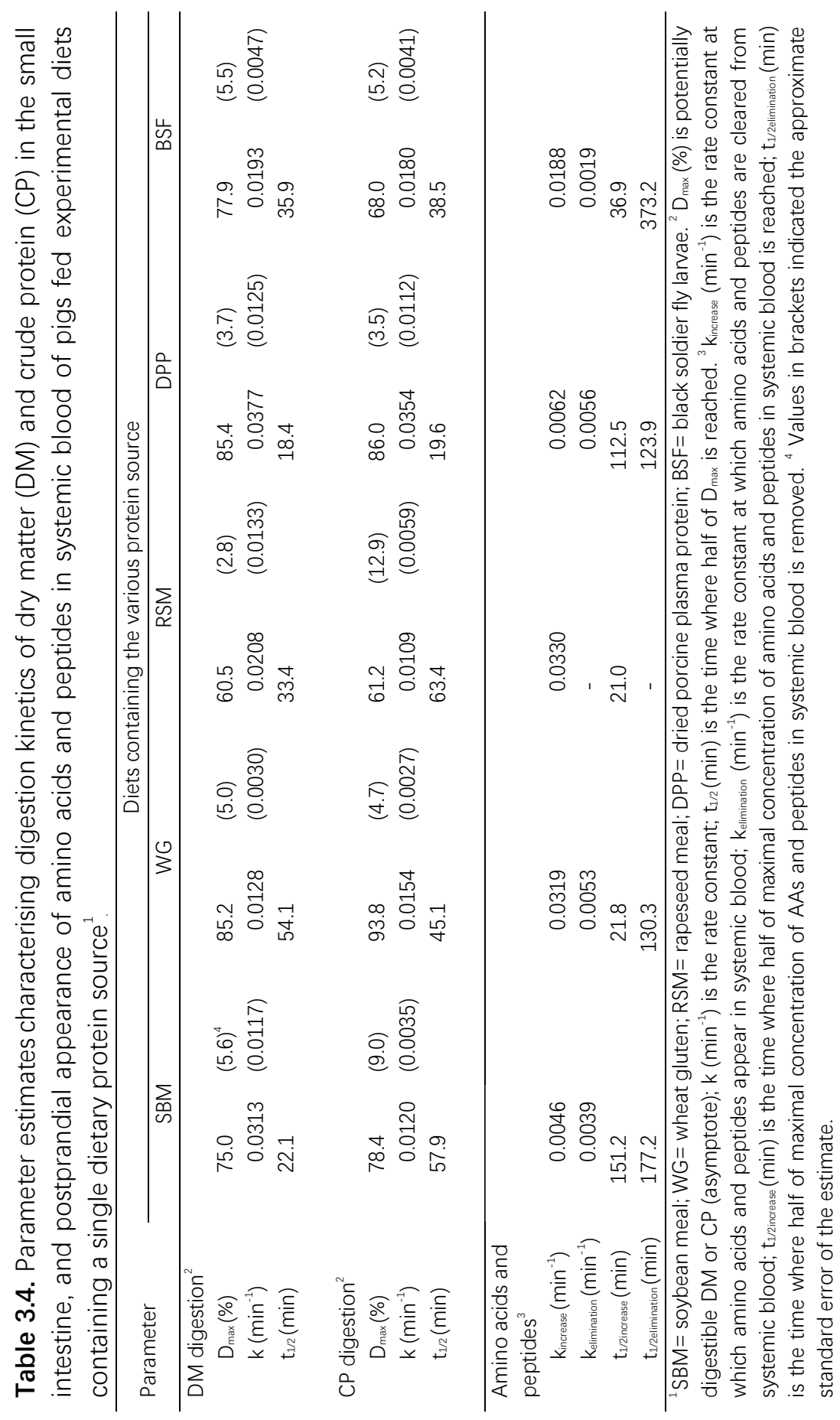


Molecular weight distribution of protein and peptides in digesta of the stomach and SI

The $2 \%$ SDS solution with $100 \mathrm{mM}$ dithiothreitol solubilised $85 \pm 3 \%$ of the proteins and peptides in the digesta samples. Proteins and peptides in the diets predominantly had a molecular weight $>5 \mathrm{kDa}$ (Figure 3.2). In the stomach, the amount of peptides with a molecular weight between 5 to $10 \mathrm{kDa}$ increased for all diets. In digesta of the $\mathrm{SI}$, proteins and peptides had molecular weights either $>5 \mathrm{kDa}$ or $<1 \mathrm{kDa}$. A substantial quantity of peptides with a molecular weight $<1 \mathrm{kDa}$ was present in the $4^{\text {th }} \mathrm{SI}$ segment of pigs fed the SBM, RSM and BSF diets. The presence of protein in digesta of pigs fed the protein free diet showed that endogenous proteins and peptides (mostly with molecular weight $>5 \mathrm{kDa}$ ) were secreted in the stomach and SI. The average molecular weight distribution of proteins and peptides in digesta over the SI was similar for each of the dietary treatments (Figure 3.2). The molecular weight fractions $>5 \mathrm{kDa}$ accounted for the majority of protein in digesta in all treatments.

\section{Postprandial concentration of amino acids and peptides in systemic blood}

The postprandial concentration of AAs and peptides in systemic blood showed an interaction between time and diet $(P<0.001)$ (Figure 3.3). Two types of response were observed: a peak response for the WG and DPP diets and a plateau response for the SBM, RSM and BSF diets. The peak response showed a higher increase of plasma AAs and peptides after feeding than the plateau response. In addition, the clearance of AAs and peptides from plasma was faster in case of the diets with a peak response, whereas the plasma concentration of AAs and peptides remained close to its maximum for a longer period of time in case of the diets with a plateau response. The rate of increase ranged from $0.0046 \mathrm{~min}^{-1}$ for the SBM diet to $0.0330 \mathrm{~min}^{-1}$ for the RSM diet and the elimination rate ranged from $0.0019 \mathrm{~min}^{-1}$ for the BSF diet to $0.0056 \mathrm{~min}^{-1}$ for the DPP diet. Up to 30, 60, 90, 120 and 150 min after feeding, the WG diet showed the highest AUC in comparison to the other diets $(P<0.001)$ (Table 3.5). Up to $180 \mathrm{~min}$, the WG and DPP diets showed a higher AUC compared to the SBM and RSM diets $(P<0.05)$. Over all treatments, AUC in time after a meal was positively correlated $(r=0.73, P<0.001)$ with the amount of apparent digested protein in the SI (Figure 3.4). 

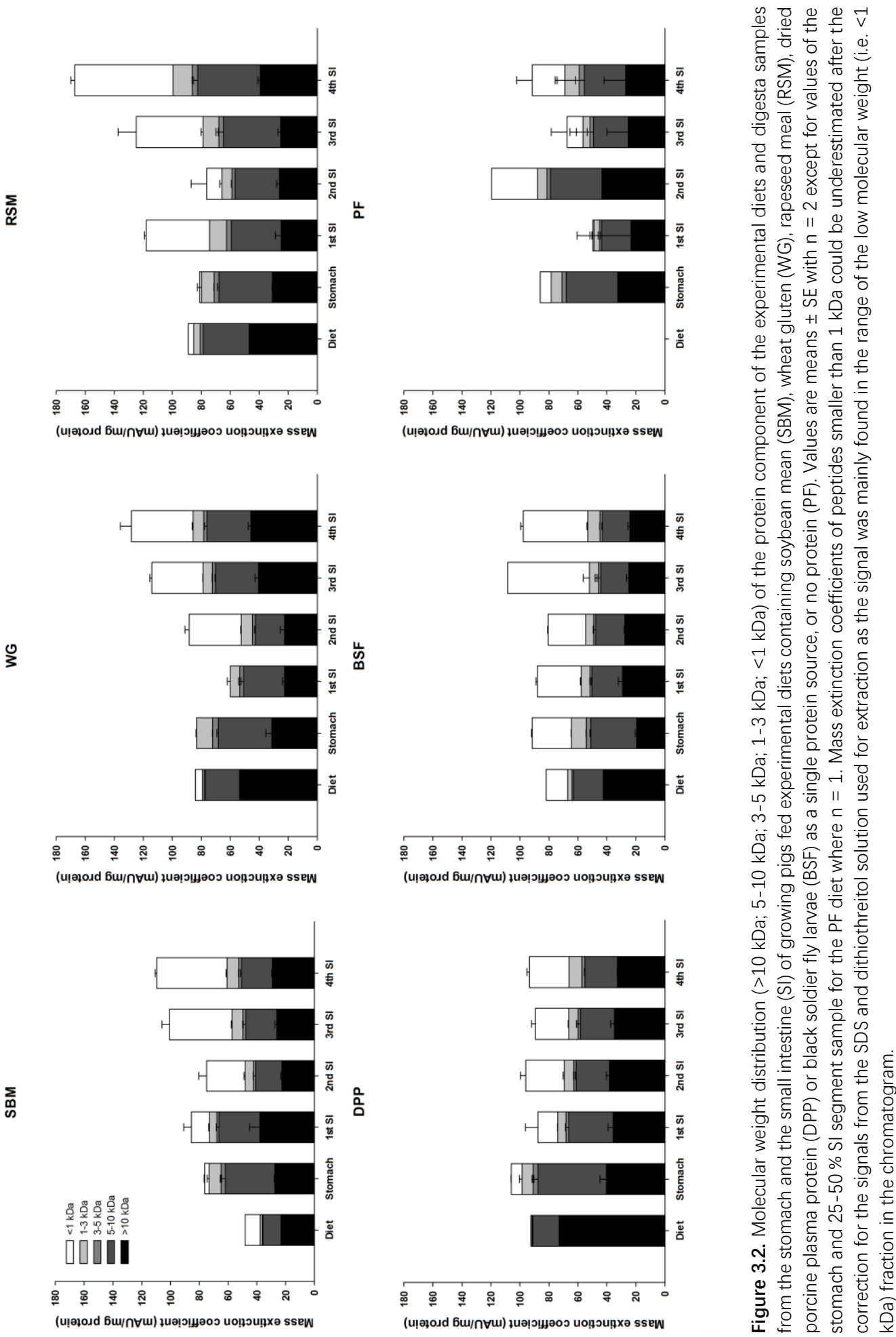

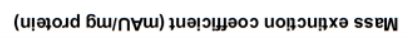




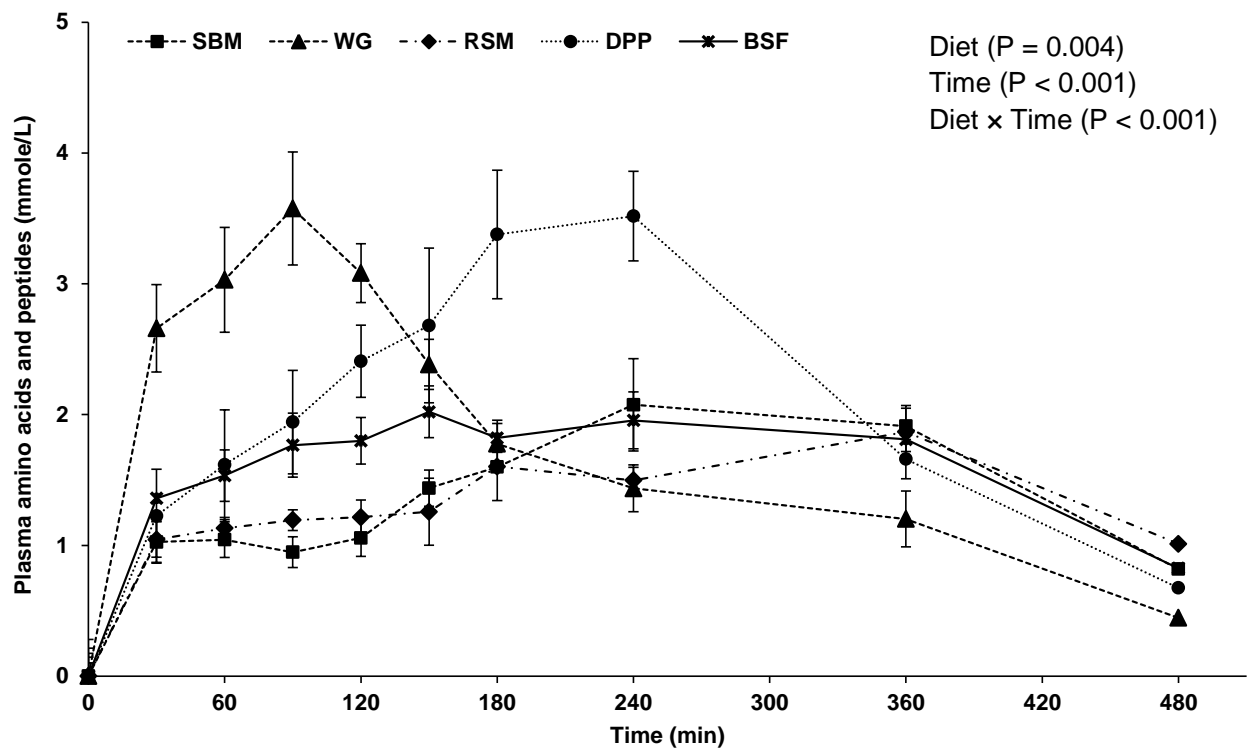

Figure 3.3. Postprandial concentration of amino acids and peptides in systemic blood of growing pigs fed experimental diets containing soybean mean (SBM), wheat gluten (WG), rapeseed meal (RSM), dried porcine plasma protein (DPP) or black soldier fly larvae (BSF) as the only dietary protein source. Values are means \pm SEM with $\mathrm{n}=4$ per diet.

Table 3.5. Quantitative postprandial concentration (expressed as area under the curve, $\mathrm{mmole} \cdot \mathrm{min} / \mathrm{L}$ ) of amino acids and peptides in systemic blood of growing pigs fed experimental diets containing a single protein source ${ }^{1}$.

\begin{tabular}{|c|c|c|c|c|c|c|c|}
\hline \multirow{2}{*}{ Time period } & \multicolumn{5}{|c|}{ Diets containing the various protein source } & \multirow{2}{*}{$\begin{array}{c}\text { Pooled } \\
\text { SEM }\end{array}$} & \multirow{2}{*}{$P$-value } \\
\hline & SBM & WG & RSM & DPP & BSF & & \\
\hline$n^{2}$ & 4 & 4 & 4 & 4 & 4 & & \\
\hline $0-30 \mathrm{~min}$ & $15.4^{b}$ & $39.9^{\mathrm{a}}$ & $9.9^{b}$ & $18.4^{\mathrm{b}}$ & $20.4^{\mathrm{b}}$ & 3.1 & $<0.001$ \\
\hline $0-60 \mathrm{~min}$ & $46.4^{b}$ & $125.2^{\mathrm{a}}$ & $42.6^{b}$ & $61.0^{b}$ & $63.8^{\mathrm{b}}$ & 8.2 & $<0.001$ \\
\hline $0-90 \mathrm{~min}$ & $76.3^{\mathrm{b}}$ & $224.3^{\mathrm{a}}$ & $77.4^{\mathrm{b}}$ & $114.4^{b}$ & $113.3^{\mathrm{b}}$ & 14.3 & $<0.001$ \\
\hline $0-120 \mathrm{~min}$ & $106.4^{b}$ & $324.2^{\mathrm{a}}$ & $113.6^{b}$ & $179.7^{b}$ & $166.8^{\mathrm{b}}$ & 20.9 & $<0.001$ \\
\hline $0-150 \mathrm{~min}$ & $143.8^{b}$ & $406.2^{\mathrm{a}}$ & $150.6^{\mathrm{b}}$ & $256.0^{b}$ & $224.1^{\mathrm{b}}$ & 26.0 & $<0.001$ \\
\hline $0-180 \mathrm{~min}$ & $189.3^{c}$ & $468.6^{a}$ & $193.5^{c}$ & $346.9^{\mathrm{ab}}$ & $281.7^{\mathrm{bc}}$ & 29.4 & $<0.001$ \\
\hline
\end{tabular}

${ }^{1} \mathrm{SBM}=$ soybean meal; $\mathrm{WG}=$ wheat gluten; $\mathrm{RSM}=$ rapeseed meal; $\mathrm{DPP}=$ dried porcine plasma protein; BSF $=$ black soldier fly larvae. ${ }^{2}$ Number of pigs of which samples were collected and analysed. ${ }^{\text {abc }}$ Means within the row without a common superscript differ $(P<0.05)$. 


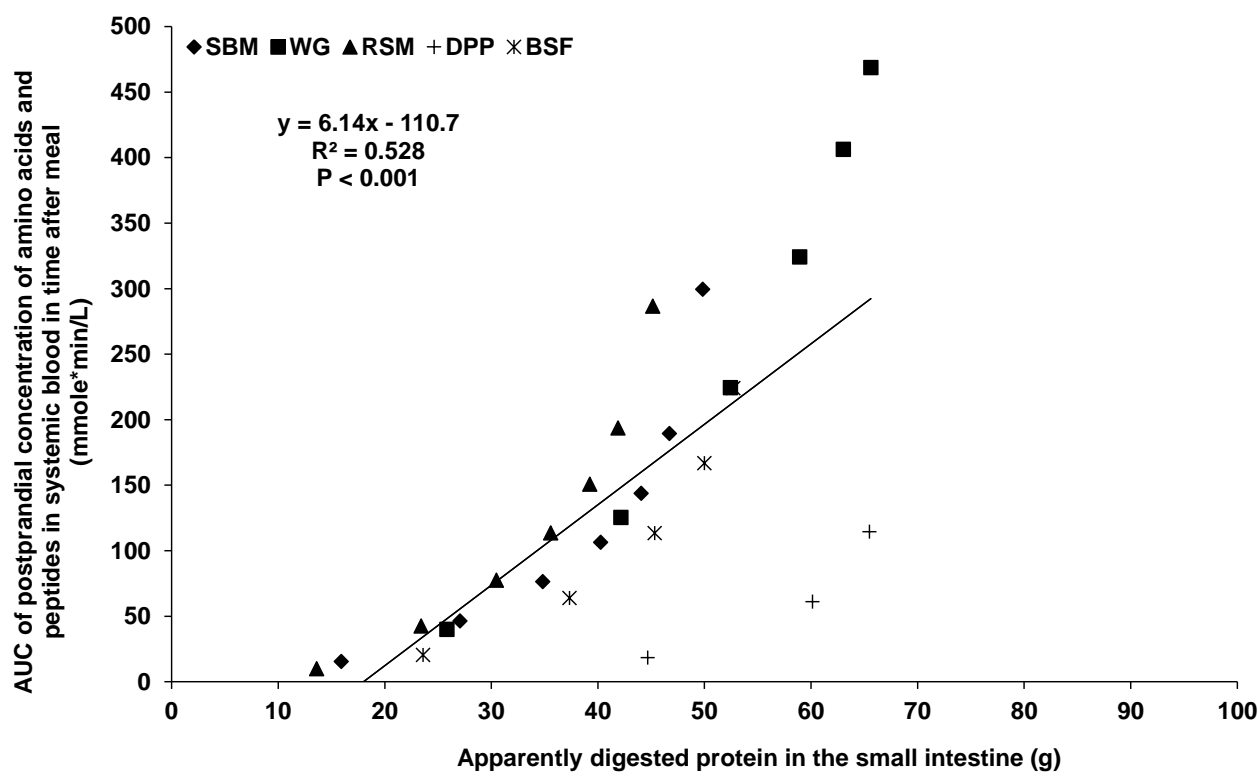

Figure 3.4. The relationship between the amount of apparently digested protein $(\mathrm{g})$ up to the end of the small intestine and the appearance of AA in systematic blood using the area under the curve (AUC) method $(\mathrm{mmole} \cdot \mathrm{min} / \mathrm{L})$ of experimental diets containing different protein sources.

\section{DISCUSSION}

The aim of the present study was to determine the in vivo protein digestion kinetics up to the end of the SI of different protein sources, and its influence on the postprandial appearance of AAs and peptides in systemic blood in pigs. Free AAs were supplemented to the diets in order to avoid severe deficiencies in the supply of essential AAs from the diets. The level of supplementation, however, was low (ranging from 0 to $6.3 \mathrm{~g} / \mathrm{kg}$ ) compared to the content of protein in the experimental diets $(160 \mathrm{~g} / \mathrm{kg})$. The differences in protein digestion kinetics of the experimental diets were, therefore, attributed to the protein sources which were included as a single protein source. Among protein sources, WG and DPP had a higher CP content than the other protein sources. Since all experimental diets were formulated isoproteineous, the inclusion level of WG and DPP in the diets was lower than the other protein sources. Maize starch was used to fill up the gap of non-protein components present in SBM, RSM and BSF in the diets with WP and DPP, resulting in a higher starch content of these diets than that of the SBM, RSM and BSF diets. The apparent ileal protein digestibility 
was approximated by the ADcp measured in the $4^{\text {th }}$ SI segment. Values for SBM, WG and RSM diets (74, 91, and $60 \%$, respectively) were lower than the tabulated values for apparent ileal protein digestibility in CVB (2016) (85, 98, and $70 \%$, respectively). This could be due to the fact that digesta samples were collected from the $4^{\text {th }} \mathrm{SI}$ segment, comprising the distal quarter of the jejunum and the entire ileum, instead of only from the end of the ileum. More undigested protein is likely to be present in the former, resulting in a lower $A D_{c p}$. The ranking of protein sources based on the $A D_{c p}$ measured in the $4^{\text {th }}$ SI segment, however, is in accordance with the ranking based on data on ileal digestibility as presented by CVB (2016). These results suggest that the differences in the extent and the kinetics of protein digestion among evaluated protein sources are as expected and can be related to the nature (e.g. chemical composition, protein conformation, physicochemical properties) of protein sources.

In pig diets, WG and DPP are considered as highly digestible protein sources while the ileal protein digestibility of RSM is relatively low (CVB, 2016). Proteins present in highly digestible protein sources are assumed to be more susceptible to hydrolysis by digestive enzymes. As a result, high molecular weight proteins and peptides are assumed to be hydrolysed into low molecular weight peptides and should be present in low quantities in digesta at the end of the SI. In contrast, proteins present in low digestible protein sources are assumed to be more resistant to enzymatic hydrolysis, resulting in the higher presence of high molecular weight proteins and peptides in digesta at the end of the SI. Assuming the former, the molecular weight distribution of proteins and peptides in digesta of pigs fed high and low digestible protein sources were expected to be different. The molecular weight distribution of proteins and peptides in digesta throughout the GIT, however, was comparable among protein sources in the present study. These results indicate that the mechanism of hydrolysis and absorption of proteins was rather similar among protein sources, although the nature of proteins present in protein sources is different, resulting in various protein digestion kinetics and digestibility. In addition, the results indicate that the hydrolysis of protein sources by digestive enzymes followed a "one-by-one" type of hydrolysis mechanism, meaning intact proteins from the protein sources are hydrolysed to low molecular weight peptides and free AAs and are absorbed by the intestinal mucosa in one sequence (Adler-Nissen, 1976).

In pigs, the absorption of AAs, and di- and tri-peptides by intestinal enterocytes takes place in the jejunum and ileum, of which the proximal jejunum is the major site of 
absorption (Low, 1979; Bröer, 2008). A slow hydrolysis of dietary proteins in the proximal part of the SI could lead to the release of AAs and di-and tri-peptides in the more distal part of the SI (i.e. $3^{\text {rd }}$ and $4^{\text {th }}$ SI segment). Since the absorption of AAs and di- and tri-peptides is less efficient in the distal part of the SI than in the proximal part of the SI, there is a high chance that these potentially digestible AAs, and di - and tripeptides are passed to the colon and considered indigestible in the small intestine. In the present study, a relatively large amount of peptides with a molecular weight $<1 \mathrm{kDa}$ was found in the digesta from the end of the SI of pigs fed the SBM, RSM and BSF diet. This might be due to the formation of indigestible peptide aggregates during enzymatic hydrolysis (Fischer et al., 2007), or to the low AD in the proximal part of the SI (i.e. $1^{\text {st }}$ and $2^{\text {nd }}$ SI segment) for the SBM, RSM and BSF diets observed in the present study. The WG diet also showed a low ADcp in the $2^{\text {nd }}$ SI segment. However, in the $3^{\text {rd }} \mathrm{SI}$ segment, the $A D_{C p}$ of the WG diet was largely much higher than that of the SBM, RSM and BSF diets. This might be due to the longer RT of the WG diet in that SI segment. These results indicate that a prolonged RT in the SI may compensate the effect of slow release of AAs, and di- and tri-peptides and result in a quantitatively higher digestibility of dietary proteins up to the end of the small intestine.

The digestion kinetics of dietary proteins was evaluated by combining data on the AD and the cumulative RT of digesta up to that SI segment. The DPP diet showed the highest fractional protein digestion rate. Although the WG diet showed a similar $A D_{C P}$ in the $4^{\text {th }}$ SI segment to the DPP diet (91 and $87 \%$, respectively), the fractional protein digestion rate of the WG diet was 2.3 times lower than that of the DPP diet (0.0154 and $0.0354 \mathrm{~min}^{-1}$, respectively). In addition, the WG and BSF diet showed a comparable fractional protein digestion rate (0.0154 and $0.0180 \mathrm{~min}^{-1}$, respectively) while the $A D_{C P}$ in the $4^{\text {th }}$ SI segment was higher for the WG diet (91\%) than for the BSF diet (68 \%). These results opposed the hypothesis that highly digestible protein sources are digested faster in the $\mathrm{SI}$ of pig. The fractional protein digestion rate is not related to the extent of protein digestion up to the end of small intestine over the protein sources evaluated in the present study.

Blood samples were collected from the ear vein to follow the postprandial appearance of AAs and peptides in systemic blood. The WG diet showed a more rapid and pronounced postprandial appearance of AAs and peptides in systemic blood than SBM, RSM and BSF diets. A more rapid and pronounced postprandial appearance can be related to a high passage rate of digesta through the stomach (Gaudichon et al., 1994), a high hydrolysis rate of dietary proteins in the stomach and small intestine 
(Guan et al., 2016), and/or a high absorption rate of AAs and peptides by the intestinal mucosa. Indeed, the WG diet showed a numerically lower RT in the stomach and a numerically higher $\mathrm{AD}_{\mathrm{CP}}$ in the proximal SI than SBM, RSM and BSF diets. The differences were not statistically significant due to the relatively large animal variation within each treatment. Although the DPP diet also showed a similar RT in the stomach and $A D_{C P}$ in the proximal SI to the WG diet, a delay in the postprandial appearance of AAs and peptides in systemic blood of pigs fed the DPP diet was observed. This might be due to differences in the extent of AA metabolism in the intestinal mucosa and the liver of protein sources related to differences in their AA profile. It should be noted that $\mathrm{TiO}_{2}$ was used as an indigestible marker to estimate RT of digesta along the GIT. This is a water-insoluble marker and therefore the RT calculated based on $\mathrm{TiO}_{2}$ represents primarily the RT of the solid fraction of digesta (Solà-Oriol et al., 2010). Studies in pigs have shown that the solid fraction of digesta had a longer RT in the stomach than the liquid fraction (Gregory et al., 1990; Johansen et al., 1996; Davis et al., 2001). In our previous study, WG and DPP showed a high protein solubility under the conditions as prevailing in the stomach (Chapter 2). The use of $\mathrm{TiO}_{2}$, therefore, might hinder the determination of RT for soluble proteins. As a consequence the RT for soluble proteins present in the WG and DPP diet in the stomach could be overestimated.

The linear relationship between data on the kinetics of protein digestion up to the end of the SI and the kinetics of postprandial appearance of AAs and peptides in systemic blood was determined. Studies on digestion kinetics of nutrients commonly provide information on the potentially digestible fraction (i.e. the extent) and the fractional digestion rate, similar to results presented in the present study. The digestion rate of a nutrient in an ingredient or diet is basically independent of its extent of digestion. In quantitative nutrition research, comparison of parameters accounting for both the fractional rate and the extent is preferred over comparison of fractional rates only. An approach, therefore, was taken to relate the quantitative disappearance of AAs and peptides from the lumen of the SI to the quantitative appearance of AAs and peptides in systemic blood. Over all dietary treatments, the concentration of AAs and peptides in systemic blood after a meal was positively correlated to the amount of apparent digested protein up to the end of the SI.

It should be noted that leucine was used as a standard to determine the concentration of total AAs and peptides in blood plasma in the ninhydrin assay. The molar extinction coefficient of individual $A A$ in this assay, however, was shown to range from 0 for 
proline to 1.08 for lysine relative to leucine (Friedman, 2004). Moreover, one peptide molecule gives a similar molar extinction coefficient to one molecule of free AA. The concentration of AAs in plasma, therefore, could be underestimated in the case of high presence of peptides relative to free AAs using this method. The concentration and profile of AAs and peptides in systemic blood could be different from that of AAs and peptides absorbed from the intestinal lumen by enterocytes because of the metabolism of AAs in the intestinal mucosa and in the liver and other organs and tissues (Stoll et al., 1998a;b). In addition, it was shown that the extent of intestinal and hepatic metabolism of absorbed AAs can be affected by dietary protein source (Nunes et al., 1991). The postprandial appearance of AAs and peptides in systemic blood, therefore, is the net result of AAs and peptides being absorbed from the lumen of the SI and AAs and peptides being removed from the blood circulation for metabolism in organs and tissues, and as a result does not completely resemble the apparent disappearance of AAs and peptides from the lumen of the SI. Despite this, the results suggest that observations on changes in AA and peptide concentration after a meal in systemic blood cab be used to study protein digestion kinetics. 


\section{CONCLUSIONS}

The kinetics of protein digestion and postprandial appearance of AAs and peptides in systemic blood of pigs differed among diets containing different protein source. WG and DPP can be regarded as fast digestible sources while SBM, RSM and BSF as more slowly digestible protein sources. The kinetics of appearance of AAs and peptides in blood was positively correlated to the kinetics of disappearance of AAs and peptides from the lumen of the SI. A more rapid and pronounced postprandial appearance of AAs and peptides in blood can be explained by a high passage rate of digesta through the stomach and/or a high rate of enzymatic hydrolysis of proteins and absorption of AAs and peptides in the SI.

\section{ACKOWLEDGEMENTS}

The authors gratefully acknowledge the financial support from the Wageningen UR "IPOP Customized Nutrition" programme financed by Wageningen UR (Wageningen, the Netherlands), the Dutch Ministry of Economic Affairs, Agriculture \& Innovation (the Hague, the Netherlands), WIAS graduate school (Wageningen, the Netherlands), Nutreco (Boxmeer, the Netherlands) and Darling Ingredients International (Irving, TX, USA). 


\section{REFERENCES}

Adler-Nissen, J. 1976. Enzymic hydrolysis of proteins for increased solubility. J. Agric. Food Chem. 24:10901093.

Boirie, Y., M. Dangin, P. Gachon, M. P. Vasson, J. L. Maubois, and B. Beaufrère. 1997. Slow and fast dietary proteins differently modulate postprandial protein accretion. Proc. Natl. Acad. Sci. 94:14930-14935.

Bos, C., C. C. Metges, C. Gaudichon, K. J. Petzke, M. E. Pueyo, C. Morens, J. Everwand, R. Benamouzig, and D. Tomé. 2003. Postprandial kinetics of dietary amino acids are the main determinant of their metabolism after soy or milk protein ingestion in humans. J. Nutr. 133:1308-1315

Bröer, S. 2008. Amino acid transport across mammalian intestinal and renal epithelia. Physiol. Rev. 88:249286.

CVB. 2016. Chemical compositions and nutritional values of feed ingredients. Centraal Veevoeder Bureau, Wageningen, the Netherlands.

Dangin, M., Y. Boirie, C. Garcia-Rodenas, P. Gachon, J. Fauquant, P. Callier, O. Ballèvre, and B. Beaufrère. 2001. The digestion rate of protein is an independent regulating factor of postprandial protein retention. Am. J. Physiol. Metab. 280:340-348.

Davis, S. S., L. Illum, and M. Hinchcliffe. 2001. Gastrointestinal transit of dosage forms in the pig. J. Pharm. Pharmacol. 53:33-39.

Drew, M. D., T. C. Schafer, and R. T. Zijlstra. 2012. Glycemic index of starch affects nitrogen retention in grower pigs. J. Anim. Sci. 90:1233-1241.

Fischer, M., A. G. J. Voragen, S. R. Piersma, L. V. Kofod, C. I. Joergensen, P. Guggenbuhl, C. S. Nunes, and H. Gruppen. 2007. Presence of indigestible peptide aggregates of soybean meal in pig ileal digesta residue. J. Sci. Food Agric. 87:2229-2238.

Friedman, M. 2004. Applications of the ninhydrin reaction for analysis of amino acids, peptides, and proteins to agricultural and biomedical sciences. J. Agric. Food Chem. 52:385-406.

Gaudichon, C., N. Roos, S. Mahé, H. Sick, C. Bouley, and D. Tomé. 1994. Gastric emptying regulates the kinetics of nitrogen absorption from ${ }^{15} \mathrm{~N}$-labeled milk and ${ }^{15} \mathrm{~N}$-labeled yogurt in miniature pigs. J. Nutr. 124:1970-1977.

Gregory, P. C., M. McFadyen, and D. V. Rayner. 1990. Pattern of gastric emptying in the pig: relation to feeding Br. J. Nutr. 64:45-58.

Guan, G. P., B. E. Tan, K. Yao, J. Fang, G. Z. He, T. J. Li, H. Sun, and Y. L. Yin. 2016. Dynamic profiles of amino acids released from different nitrogen composited diets in the jejunum of pigs. J. Anim. Sci. 94(supplement):283-285

Hunt, J. N., and D. F. Stubbs. 1975. The volume and energy content of meals as determinants of gastric emptying. J. Physiol. 245:209-225.

ISO. 1999a. ISO 6492:1999. Animal feeding stuffs-Determination of fat content. International Organization for Standardization, Geneva, Switzerland.

ISO. 1999b. ISO 6496:1999. Animal feeding stuffs-Determination of moisture and other volatile matter content. International Organization for Standardization, Geneva, Switzerland.

ISO. 2002. ISO 5984:2002. Animal feeding stuffs-Determination of crude ash content. International Organization for Standardization, Geneva, Switzerland.

ISO. 2004. ISO 15914-1:2004. Animal feeding stuffs-Enzymatic determination of total starch content. International Organization for Standardization, Geneva, Switzerland.

ISO. 2005a. ISO 5983-1:2005. Animal feeding stuffs-Determination of $\mathrm{N}$ content and calculation of crude protein content-Part 1: Kjeldahl method. International Organization for Standardization, Geneva, Switzerland.

ISO. 2005b. ISO 5983-1:2005. Animal feeding stuffs-Determination of amino acid content. International Organization for Standardization, Geneva, Switzerland.

ISO. 2008. ISO 16634-1:2008. Food products-Determination of the total $\mathrm{N}$ content by combustion according to the Dumas principle and calculation of the crude protein content-Part 1: Oilseeds and animal feeding stuffs. International Organization for Standardization, Geneva, Switzerland. 
Jansman, A. J. M., P. van Leeuwen, W. Crala, and I. Haaksman. 1997. Dynamics of amino acids absorption in pigs. Proc. of the 7th Int. Sympo. on Dig. Physiol. in Pigs, Saint Malmo, France. pp.316-320.

Johansen, H. N., K. E. B. Knudsen, B. Sandström, and F. Skjøth. 1996. Effects of varying content of soluble dietary fibre from wheat flour and oat milling fractions on gastric emptying in pigs. Br. J. Nutr. 75:339351.

Lee, Y. P., and T. Takahashi. 1966. An improved colorimetric determination of amino acids with the use of ninhydrin. Anal. Biochem. 14:71-77.

Liu, S. Y., and P. H. Selle. 2015. A consideration of starch and protein digestive dynamics in chicken-meat production. Worlds. Poult. Sci. 71:297-310.

Low, A. G. 1979. Studies on digestion and absorption in the intestines of growing pigs. Br. J. Nutr. 41:147156.

Malabat, C., and C. Rabiller. 2001. Emulsifying and foaming properties of native and chemically modified peptides from the 2S and 12S proteins of rapeseed (Brassica napus L.). J. Am. Oil Chem. 78:235-242.

Morifuji, M., M. Ishizaka, S. Baba, K. Fukuda, H. Matsumoto, J. Koga, M. Kanegae, and M. Higuchi. 2010. Comparison of different sources and degrees of hydrolysis of dietary protein: effect on plasma amino acids, dipeptides, and insulin responses in human subjects. J. Agric. Food Chem. 58:8788-8797.

Myers, W. D., P. A. Ludden, V. Nayigihugu, and B. W. Hess. 2004. Technical note: a procedure for the preparation and quantitative analysis of samples for titanium dioxide. J. Anim. Sci. 82:179-183.

NRC. 2012. Nutrient requirements of swine. Eleventh revised edition. National Academic Press, Washington, D.C., USA.

Nunes, C. S., I. Galibois, A. Rérat, L. Savoie, and P. Vaugelade. 1991. Hepatic and portal-drained viscera balances of amino acids, insulin, glucagon and gastrin in the pig after ingestion of casein or rapeseed proteins. Reprod. Nutr. Dev. 31:217-231.

Selle, P. H., A. J. Cowieson, N. P. Cowieson, and V. Ravindran. 2012. Protein-phytate interactions in pig and poultry nutrition: a reappraisal. Nutr. Res. Rev. 25:1-17.

Solà-Oriol, D., D. Torrallardona, and J. Gasa. 2010. Role of dietary fibre source and meal size on the ileal transit of digesta in growing pigs. Livest. Sci. 133:67-69.

Stevens, B. R. 1992. Amino acid transport in intestine. Mammalian Amino Acid Transport, Springer, USA. pp. 149-163.

Stoll, B., D. G. Burrin, J. Henry, H. Yu, F. Jahoor, and P. J. Reeds. 1998a. Dietary amino acids are the preferential source of hepatic protein synthesis in piglets. J. Nutr. 128:1517-1524.

Stoll, B., J. Henry, P. J. Reeds, H. Yu, F. Jahoor, and D. G. Burrin. 1998b. Catabolism dominates the first-pass intestinal metabolism of dietary essential amino acids in milk protein-fed piglets. J. Nutr. 128:606-614.

Tang, J. E., D. R. Moore, G. W. Kujbida, M. A. Tarnopolsky, and S. M. Phillips. 2009. Ingestion of whey hydrolysate, casein, or soy protein isolate: effects on mixed muscle protein synthesis at rest and following resistance exercise in young men. J. Appl. Physiol. 107:987-992.

Tonheim, S. K., A. Nordgreen, I. Høgøy, K. Hamre, and I. Rønnestad. 2007. In vitro digestibility of watersoluble and water-insoluble protein fractions of some common fish larval feeds and feed ingredients. Aquaculture 262:426-435.

van den Borne, J. J. G. C., J. W. Schrama, M. J. W. Heetkamp, M. W. A. Verstegen, and W. J. J. Gerrits. 2007. Synchronising the availability of amino acids and glucose increases protein retention in pigs. Animal 1:666-674.

van Vuuren, A. M., C. J. van der Koelen, H. Valk, and H. de Visser. 1993. Effects of partial replacement of ryegrass by low protein feeds on rumen fermentation and nitrogen loss by dairy cows. J. Dairy Sci. 76:2982-2993.

Wilfart, A., Y. Jaguelin-Peyraud, H. Simmins, J. Noblet, J. van Milgen, and L. Montagne. 2007. A step-wise in vitro method to estimate kinetics of hydrolysis of feeds. Livest. Sci. 109:179-181. 
76|P a g e 
Chapter 4

Protein digestion kinetics in the small intestine of broilers differs among protein sources

H. Chen ${ }^{\star}$, P.A. Wierenga ${ }^{\dagger}$, W.H. Hendriks ${ }^{\star}$, A.J.M. Jansman ${ }^{\ddagger}$

"Animal Nutrition Group, Wageningen University \& Research, The Netherlands

${ }^{\dagger}$ Laboratory of Food Chemistry, Wageningen University \& Research, The Netherlands

'Wageningen Livestock Research, The Netherlands 


\section{ABSTRACT}

The aim of the present study was to determine the in vivo protein digestion kinetics up to the end of the small intestine (SI) of six protein sources (soybean meal (SBM), soy protein isolate (SPI), wheat gluten (WG), rapeseed meal (RSM), dried porcine plasma protein (DPP), and black soldier fly larvae (BSF)) in broilers. A total of 378 26-day-old male broilers with average body weight of $1430 \pm 48 \mathrm{~g}$ were randomly allocated to 42 pens. Pens were randomly allocated to one of the seven diets (i.e. a basal diet and six experimental diets with the respective protein sources). At dissection, digesta samples from the crop, gizzard, duodenum, proximal jejunum, distal jejunum, and ileum were quantitatively collected. Apparent digestibility (AD) of dry matter (DM) and crude protein (CP), and retention time (RT) of the solid and liquid fractions of digesta along the crop, gizzard and small intestine (SI) were determined to calculate protein digestion kinetics. The $A D_{C p}$ was affected by the diet in the $S I(P<0.001)$, of which the WG diet showed the highest and the RSM diet showed the lowest $A D_{c p}$ along the SI. Over all experimental diets, the solid fraction of digesta showed a longer RT in the gizzard $(P<0.01)$ and tended to show a longer RT in the SI than the liquid fraction of digesta $(P=0.052)$. The RT for the solid fraction of digesta was affected by the diet in the crop, gizzard and duodenum $(P<0.05)$ but not in the proximal jejunum, distal jejunum and ileum. The initial rate of CP digestion ranged from $4 \mathrm{~g} \cdot \mathrm{min}^{-1}$ per $\mathrm{kg}$ diet for the RSM diet to $67 \mathrm{~g} \cdot \mathrm{min}^{-1}$ per $\mathrm{kg}$ diet for the SPI diet. In conclusion, SPI, WG and DPP can be regarded as fast digestible protein sources while SBM, RSM and BSF as more slowly digestible protein sources in broilers. 


\section{INTRODUCTION}

An efficient utilisation of dietary protein is economically important in modern-day broiler production particularly in light of the forthcoming global protein scarcity. Amino acids (AAs) and peptides provided via dietary proteins are used to synthesise body proteins or as an energy source after deamination. The efficiency of protein utilisation depends on the balance between these two processes, of which a higher efficiency relates to a higher body protein synthesis. The simultaneous availability of AAs and energy increases protein synthesis in organs and tissues (Geiger, 1950; van den Borne et al., 2007). As such, the fate of dietary AAs and peptides in the post absorptive metabolism depends on the kinetics of protein digestion relative to the digestion kinetics of energy providing nutrients in the diets such as starch. The kinetics of starch digestion for various feed ingredients, both in vitro and in vivo, has been extensively studied in broilers (Weurding, 2002). The digestion rate of starch in the small intestine (SI) of chickens varied substantially among feed ingredients ranging from $0.009 \mathrm{~min}^{-1}$ for raw potato starch to $0.071 \mathrm{~min}^{-1}$ for tapioca starch (Weurding et al., 2001). Information on the digestion kinetics of protein in different feed ingredients in broilers is limited. Such data are required to ensure the synchronisation of the supply of dietary energy and protein, which could improve protein retention and efficiency of protein utilisation in broiler production (Liu and Selle, 2015).

The overall kinetics of dietary protein digestion is related to three aspects: 1) the passage rate of digesta along the gastrointestinal tract (GIT), 2) the hydrolysis rate of dietary proteins in the GIT, and 3) the absorption rate of AAs and peptides by the intestinal mucosa. In broiler chickens, the passage rate of digesta along the GIT can be affected by diet type (i.e. purified and non-purified diets) and composition. For example, a semi-purified diet with dextrose and distillers dried grains with solubles showed a $8 \%$ lower digesta retention time along the GIT than a corn-soybean meal (SBM)-based diet in broilers (5.13 vs. 5.58 h) (Rochell et al., 2012). Moreover, it has been shown that an increase in the concentration of dietary insoluble non-starch polysaccharides tended to increase digesta retention time in the crop and gizzard of laying hens by $20 \%$ (van Krimpen et al., 2011). As for the hydrolysis rate of dietary proteins, it is affected by protein conformation (Malabat and Rabiller, 2001), protein solubility (Tonheim et al., 2007), and by the interaction between proteins and non-protein constituents in protein sources (Selle et al., 2012). In addition, diet composition could affect digestive enzymes activity and secretion, thereby influencing the rate of protein hydrolysis. For example, 
a diet with high tannin concentration reduced the activity of trypsin in the ileum of pigs compared to a diet with a low tannin concentration. This likely contributed to a lower ileal protein digestibility for the diet with high tannin concentration (Jansman et al., 1994). In addition, in broilers, eight peptidases were shown to be involved in the digestion of a SBM diet, whereas only six peptidases were involved for a rapeseed meal (RSM) diet (Recoules et al., 2017). This could possibly partly explain why SBM shows a higher ileal protein digestibility than RSM in broilers (CVB, 2016). With regard to the absorption rate of $A A s$ and peptides by the intestinal mucosa, it was shown to be regulated by the luminal concentration of AAs and peptides in mice and pigs (Stevens, 1992).

The objective of the present study was to determine the in vivo protein digestion kinetics up to the end of the SI of different common and alternative protein sources used as feed ingredients in diets for broilers. Protein digestion kinetics were studied by determining digesta retention time, protein digestibility and molecular weight distribution of soluble proteins and peptides in digesta along the SI of broilers. It was hypothesized that protein sources with a higher ileal protein digestibility are digested faster (i.e. having a higher initial digestion rate) in the SI of broilers than protein sources with a lower ileal protein digestibility.

\section{MATERIALS AND METHODS}

\section{Protein sources and experimental diets}

The protein sources evaluated were SBM, soy protein isolate (SPI), wheat gluten (WG), RSM (all commodity batches obtained via Research Diet Services, Wijk bij Duurstede, the Netherlands), dried porcine plasma protein (DPP) (obtained from Darling Ingredients Inc., Irving, TX, USA), and black soldier fly larvae meal (BSF) (obtained from Protix, Dongen, the Netherlands). Initially, all six experimental diets were formulated isoproteineous (CP, $168 \mathrm{~g} / \mathrm{kg}$ as-fed basis) and protein sources were included as a single protein source in the experimental diets. Free AAs were added so the diets to meet at least $80 \%$ of the requirement of the limiting amino acids in broilers (CVB, 2009). For BSF, information on the AA profile and ileal AA digestibility was obtained from (Veldkamp et al., 2012; De Marco et al., 2015). The total level of supplemented free AAs ranged from $0 \mathrm{~g} / \mathrm{kg}$ diet (as-fed basis) for the RSM diet to $17.5 \mathrm{~g} / \mathrm{kg}$ diet (as-fed basis) for the WG diet. However, feed intake over experimental day 7 to 12 appeared to be 
low for birds receiving the SPI, WG, DPP and BSF diets, which was possibly related to the fine physical structure of these diets, compared to the SBM and RSM diets. To further limit differences in feed intake between birds of the different experimental treatments, from day 13 onwards, $100 \mathrm{~g} / \mathrm{kg}$ (additional) SBM was included on top of all experimental diets. In addition, a basal diet with low protein content, containing only $91 \mathrm{~g} / \mathrm{kg} \mathrm{SBM}$, was used as a reference diet in the experiment.

Titanium dioxide $\left(\mathrm{TiO}_{2}\right)$ was included in all diets as an indigestible solid marker at $2.1 \mathrm{~g} / \mathrm{kg}$ diet (as-fed basis). In addition, chromium-ethylenediamine tetraacetic acid (Cr-EDTA) was included as an indigestible soluble marker at $1.7 \mathrm{~g} / \mathrm{kg}$ diet (as - fed basis). All diets were produced by Research Diet Services (Wijk bij Duurstede, the Netherlands). The ingredient composition of the experimental diets is presented in Table 4.1.

\section{Design, animals and housing}

This study was approved by the Animal Care and Use Committee of Wageningen University \& Research (Wageningen, the Netherlands). The experiment followed a randomized complete block design. Seven diets were used: a basal diet and six experimental diets with tested protein sources. Pens were blocked on the location in the experimental room (six blocks, seven pens per block) and pens within a block were randomly allocated to one of the seven experimental diets. A total of 378, 26-day-old male broilers (Ross 308, Aviagen Group, Newbridge, UK) with average body weight of $1430 \pm 48 \mathrm{~g}$ were used. Broilers were housed in 42 pens $(1.00 \times 0.75 \mathrm{~m})$ with nine broilers in a pen. A plate was connected to the pen which allowed for excreta collection. Wood shavings were used as bedding material but were removed during the period of excreta collection. The ambient temperature was kept constant at $21^{\circ} \mathrm{C}$. From experimental day 1 to 15 , lighting schedule followed a 16L : 8D regime. From day 16 to 20 , lights were continuous on (24L : OD). The relative humidity was between 40 and $70 \%$ throughout the experimental period.

\section{Feeding}

From day 1 to 6 , broilers were fed a commercial diet and gradually adapted to the experimental diets. From day 7 to 12, broilers were fed the experimental diets containing the respective protein sources. From day 13 to 20, broilers were fed the experimental diets including the additional $100 \mathrm{~g} / \mathrm{kg}$ of SBM. The experimental diets were provided in a mash form. Throughout the entire experimental period, broilers had unlimited access to feed and water. The broilers fed the basal diet received the SBM 
diet from day 1 to 12 and were gradually adapted to the basal diet from day 13 to 16 . At day 17 and 18, these broilers were only fed the basal diet.

\section{Sample collection and dissection procedure}

Total feed intake and body weight per pen were recorded at day 7,12 and 20. Average daily feed intake (ADFI) and body weight gain (ADG) were calculated between day 12 and 20. Feed conversion ratio (FCR) was calculated by dividing total feed intake by total body weight gain, including dead birds. At the dissection days (day 19 and 20), broilers were euthanized by electrocution being placed on their posterior side and the body cavity was opened, after which the GIT from the crop to the cloaca was carefully removed. The GIT was carefully located horizontally on the table without disturbing the digesta and separated into crop, proventriculus, gizzard, duodenum, proximal jejunum

$\left(1^{\text {st }}\right.$ half of the jejunum), distal jejunum ( $2^{\text {nd }}$ half of the jejunum), ileum, caeca and colon. The jejunum and the ileum were separated at the Meckel's diverticulum. Throughout the entire dissection, care was taken to prevent the movement of digesta. Digesta from these GIT segments was quantitatively collected by gentle stripping. The collected digesta samples were freeze-dried and analysed for DM, nitrogen ( $N$ ), and markers to calculate digestibility of DM and CP, and retention time of the solid and liquid fraction of digesta along the GIT.

\section{Chemical analysis}

All chemical analyses were performed according to standard laboratory methods. The experimental diets were analysed for dry matter (DM) (method ISO 6496; ISO, 1999a), ash (method ISO 5984; ISO, 2002), acid-hydrolysed ether extract (method ISO 6492; ISO 1999b), starch (method ISO 15914; ISO, 2004), total sugars as reducing sugars (van Vuuren et al., 1993) and $\mathrm{N}$ by the Kjedahl method (method ISO 5983-1; ISO, 2005a). A factor of 6.25 was used to calculate the crude protein (CP) content from analysed $\mathrm{N}$. The protein sources were analysed for AA composition (method ISO 13903; ISO, 2005b). The $\mathrm{N}$ content of digesta and excreta samples was determined using the Dumas method (method ISO 16634-1; ISO, 2008) using a Flash EA 1112 NC Analyzer (Thermo Fisher Scientific, Waltham, MA, USA). The experimental diets, digesta and excreta samples were analysed for their Ti (Myers et al., 2004) and $\mathrm{Cr}$ concentration (Williams et al., 1962; van Bussel et al., 2010). 
Table 4.1. Composition of the experimental diets ( $\mathrm{g} / \mathrm{kg}$, as-fed basis otherwise stated).

\begin{tabular}{|c|c|c|c|c|c|c|c|}
\hline \multirow[b]{2}{*}{ Ingredients } & \multicolumn{7}{|c|}{ Diets containing the various protein source ${ }^{1}$} \\
\hline & SBM & SPI & WG & RSM & PP & BSF & Basal \\
\hline Soybean meal & 404.2 & 90.9 & 90.9 & 90.9 & 90.9 & 90.9 & 90.9 \\
\hline Soy protein isolate & 0.0 & 177.2 & 0.0 & 0.0 & 0.0 & 0.0 & 0.0 \\
\hline Wheat gluten & 0.0 & 0.0 & 165.7 & 0.0 & 0.0 & 0.0 & 0.0 \\
\hline Rapeseed meal & 0.0 & 0.0 & 0.0 & 454.5 & 0.0 & 0.0 & 0.0 \\
\hline Dried porcine plasma protein & 0.0 & 0.0 & 0.0 & 0.0 & 178.5 & 0.0 & 0.0 \\
\hline Insect protein meal & 0.0 & 0.0 & 0.0 & 0.0 & 0.0 & 262.0 & 0.0 \\
\hline Maize starch & 259.3 & 426.7 & 425.8 & 130.1 & 424.7 & 331.5 & 599.5 \\
\hline Sucrose & 82.6 & 82.6 & 82.6 & 82.6 & 82.6 & 82.6 & 82.6 \\
\hline Dextrose & 41.3 & 41.3 & 41.3 & 41.3 & 41.3 & 41.3 & 41.3 \\
\hline Oat hulls & 82.6 & 82.6 & 82.6 & 82.6 & 82.6 & 82.6 & 82.6 \\
\hline Arbocel & 41.3 & 41.3 & 41.3 & 41.3 & 41.3 & 41.3 & 41.3 \\
\hline Soy oil & 55.7 & 12.1 & 7.2 & 60.7 & 12.1 & 8.0 & 13.8 \\
\hline Mineral and vitamin premix ${ }^{1}$ & 4.1 & 4.1 & 4.1 & 4.1 & 4.1 & 4.1 & 4.1 \\
\hline Limestone & 9.3 & 16.5 & 10.5 & 1.2 & 9.8 & 16.5 & 10.2 \\
\hline Salt & 3.1 & 3.4 & 0.8 & 3.1 & 0.0 & 1.7 & 3.4 \\
\hline Monocalcium phosphate & 9.4 & 10.7 & 12.7 & 2.3 & 13.6 & 11.2 & 14.5 \\
\hline Potassium carbonate & 0.0 & 4.6 & 10.2 & 0.2 & 10.8 & 8.6 & 10.6 \\
\hline Sodium bicarbonate & 0.0 & 0.3 & 4.4 & 1.2 & 0.0 & 3.2 & 1.3 \\
\hline L-Lysine HCL & 0.0 & 0.0 & 6.9 & 0.0 & 0.0 & 2.4 & 0.0 \\
\hline DL-Methionine & 1.7 & 0.0 & 1.1 & 0.0 & 2.0 & 3.0 & 0.0 \\
\hline L-Threonine & 0.0 & 1.8 & 2.1 & 0.0 & 0.0 & 0.9 & 0.0 \\
\hline L-Tryptophan & 0.0 & 0.0 & 0.2 & 0.0 & 0.0 & 0.0 & 0.0 \\
\hline L-Arginine & 0.6 & 0.0 & 3.6 & 0.0 & 1.0 & 3.6 & 0.0 \\
\hline L-Isoleucine & 0.9 & 0.0 & 0.7 & 0.0 & 0.7 & 0.7 & 0.0 \\
\hline L-Valine & 0.0 & 0.0 & 1.5 & 0.0 & 0.0 & 0.1 & 0.0 \\
\hline $\mathrm{TiO}_{2}$ & 2.1 & 2.1 & 2.1 & 2.1 & 2.1 & 2.1 & 2.1 \\
\hline Cr-EDTA & 1.7 & 1.7 & 1.7 & 1.7 & 1.7 & 1.7 & 1.7 \\
\hline \multicolumn{8}{|l|}{ Calculated nutrient composition } \\
\hline $\mathrm{ME}^{2}, \mathrm{MJ} / \mathrm{kg}$ as-fed & 11.5 & 11.5 & 12.0 & 10.0 & 11.7 & 11.5 & 11.9 \\
\hline Ash & 5.6 & 5.9 & 5.3 & 5.4 & 5.9 & 7.7 & 5.4 \\
\hline Crude protein & 19.5 & 19.5 & 19.5 & 19.5 & 19.5 & 19.5 & 4.7 \\
\hline Starch & 22.6 & 36.4 & 37.4 & 12.0 & 36.2 & 29.5 & 50.8 \\
\hline Sugars & 17.5 & 14.2 & 14.6 & 18.4 & 14.2 & 14.2 & 14.2 \\
\hline Non-starch polysaccharides & 19.2 & 14.0 & 12.7 & 28.4 & 13.3 & 17.7 & 13.3 \\
\hline Calcium & 6.3 & 8.3 & 6.5 & 5.4 & 6.3 & 16.8 & 6.6 \\
\hline Available phosphorus & 2.9 & 2.9 & 3.0 & 2.5 & 2.9 & 2.9 & 3.0 \\
\hline Sodium & 1.4 & 1.7 & 1.7 & 1.8 & 4.3 & 1.7 & 1.7 \\
\hline Digestible Lys & 11.9 & 11.9 & 10.4 & 11.0 & 15.2 & 11.2 & 2.9 \\
\hline Digestible Met + Cys & 7.3 & 7.0 & 7.4 & 8.0 & 9.5 & 7.1 & 1.3 \\
\hline Digestible Thr & 7.5 & 7.5 & 7.1 & 8.3 & 9.6 & 7.3 & 1.8 \\
\hline Digestible Trp & 2.5 & 2.4 & 2.0 & 2.5 & 2.8 & 2.3 & 0.6 \\
\hline
\end{tabular}

${ }^{1} \mathrm{SBM}=$ soybean meal; $\mathrm{SPI}=$ soy protein isolate; $\mathrm{WG}=$ wheat gluten; $\mathrm{RSM}=$ rapeseed meal; $\mathrm{DPP}=$ dried porcine plasma protein; BSF= black soldier fly larvae. ${ }^{2}$ The mineral and vitamin premix supplied per kilogram of diet: Vitamin A, 12,000 IU; cholecalciferol, $0.6 \mathrm{mg}$; vitamin E, $50 \mathrm{mg}$; vitamin B2, $7.5 \mathrm{mg}$; vitamin B6, $3.5 \mathrm{mg}$; vitamin B1, $2.0 \mathrm{mg}$; vitamin K, 1.5 mg; vitamin B12, 20 mg; choline chloride, 460 mg; anti-oxidant, $125 \mathrm{mg}$; niacin, $35 \mathrm{mg}$; pantothenic acid, $12 \mathrm{mg}$; biotin, $0.2 \mathrm{mg}$; folic acid, $1 \mathrm{mg} ; \mathrm{Mn}, 85 \mathrm{mg}$ as $\mathrm{MnO} ; \mathrm{Fe}, 80 \mathrm{mg}$ as $\mathrm{FeSO}_{4} ; \mathrm{Zn}, 60 \mathrm{mg}$ as $\mathrm{ZnSO}_{4}$; $\mathrm{Cu}, 12 \mathrm{mg}$ as CuSO ; I, $0.8 \mathrm{mg}$ as Kl; $\mathrm{Co}, 0.4 \mathrm{mg}$ as $\mathrm{CoSO}_{4}$; $\mathrm{Se}, 0.15 \mathrm{mg}$ as $\mathrm{Na}_{2} \mathrm{SeO}_{3} .{ }^{2}$ Metabolisable energy. 


\section{Size exclusion chromatography}

The molecular weight distribution of soluble proteins and peptides in digesta from the different segments of the GIT was analysed using an ÄKTA micro system (GE Healthcare, Uppsala, Sweden) with a Superdex Peptide PC 3.2/30 column (GE Healthcare). The eluent used was a $10 \mathrm{mM}$ potassium phosphate buffer with $150 \mathrm{mM} \mathrm{NaCl}$ and $2 \% \mathrm{SDS}$. Freeze-dried digesta samples $(20 \mathrm{mg}$ ) were weighed and solubilised in a $2 \%$ SDS solution with $100 \mathrm{mM}$ dithiothreitol. The samples were heated $\left(100{ }^{\circ} \mathrm{C}\right)$ for $30 \mathrm{~min}$ and then centrifuged (10 $\left.\mathrm{min}, 20,000 \mathrm{~g}, 20^{\circ} \mathrm{C}\right)$. The supernatants were diluted with the eluent in a 1:1 (v/v) ratio. Samples were then centrifuged, and $50 \mu \mathrm{L}$ of the supernatant was injected on the column. The absorbance was measured at $214 \mathrm{~nm}$. The absorbance of the samples was corrected for the signals from the SDS and dithiothreitol solution in the chromatograms. For the calibration curve, $\beta$-lactoglobulin $(18,360 \mathrm{Da})$, vitamin B12 (1,335 Da), glutathione (307 Da), glycine-proline-glycine (229 Da), phenylalanine (165 $\mathrm{Da})$ and alanine $(89 \mathrm{Da})$ were used. The chromatograms obtained were separated into molecular weight ranges of $>10 \mathrm{kDa}, 10-5 \mathrm{kDa}, 5-3 \mathrm{kDa}, 3-1 \mathrm{kDa}$ and $<1 \mathrm{kDa}$ by calculating the eluent volumes based on the calibration curve. The mass-based extinction coefficient $(\mathrm{mAU} / \mathrm{g})$ was calculated by dividing the absorbance measured at $214 \mathrm{~nm}$ by the amount of protein in the samples.

\section{Calculations and statistical analysis}

Apparent digestibility (AD) of DM and CP was calculated by equation 1:

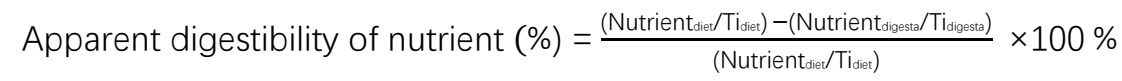

where Nutrient diet and Nutrient digesta $(\%)$ are the nutrient (DM or CP) content in the experimental diets (as-fed basis) and in the freeze-dried digesta samples, respectively, and $\mathrm{Ti}_{\text {dite }}$ and $\mathrm{Ti}_{\mathrm{i} \text { digesta }}(\%)$ are the Ti content in the same samples of experimental diets and the digesta, respectively.

Retention time of the solid ( $R T_{\text {solid }}$ ) and liquid fraction ( $R T_{\text {liquid }}$ ) of digesta in the GIT segments was calculated by equation 2 :

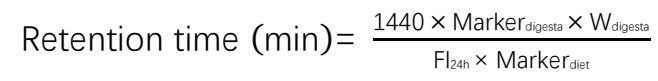

where Marker digesta $(\%)$ is the marker ( $\mathrm{Ti}$ or $\mathrm{Cr}$ ) content in the freeze-dried digesta samples, $\mathrm{W}_{\text {digesta }}(\mathrm{g})$ is the weight of freeze-dried digesta samples from the stomach or the four segments of the $\mathrm{SI}_{1} \mathrm{Fl}_{24 \mathrm{~h}}(\mathrm{~g})$ is the feed intake over $24 \mathrm{~h}$ prior to digesta sampling, 
Marker $_{\text {diet }}(\%)$ is the marker ( $\mathrm{Ti}$ or $\mathrm{Cr}$ ) content in the experimental diets (as-fed basis), and the factor 1440 is used to convert time from days to minutes.

The nutrient digestion kinetics up to the end of the $\mathrm{SI}$ of the diets containing the different protein sources were calculated by relating the $A D$ coefficient for $D M$ and $C P$ at each segment of the SI to the sum of RT solid up to that segment (Ørskov and McDonald, 1979). The curve was fitted using a first order reaction rate equation (equation 3):

$$
D_{t}=D_{\max }\left(1-e^{-k t}\right)
$$

where $D_{t}(\mathrm{~g} / \mathrm{kg}$ diet) is the digestible of $\mathrm{DM}$ or $\mathrm{CP}$ per $\mathrm{kg}$ of diet at time $\mathrm{t}(\mathrm{min})$, $D_{\max }(\mathrm{g} / \mathrm{kg}$ diet) is the potentially digestible DM or CP per $\mathrm{kg}$ of diet (asymptote), and $\mathrm{k}$ is the rate constant. The equation was fitted using the MODEL procedure of SAS (version 9.3, SAS Institute Inc., Cary, NC) and the parameter estimates and the approximate standard error of the estimates were calculated.

All variables (initial $B W$, final $B W, A D G, A D F I, F C R, R T_{\text {solid, }} R T_{\text {liquid, }}, A D_{\text {om }}$ and $A D_{c p}$ in each GIT segment) were analysed by analysis of variance using the GLM procedure of SAS with dietary protein source as a fixed effect. Residuals of all dependent variables were tested for normality and non-normally distributed data were log transformed. Probability levels of less than $5 \%$ were considered to be statistically significant, and levels between 5 to $10 \%$ were considered a trend. 


\section{RESULTS}

One bird from the treatment of SBM, RSM, DPP, BSF and basal diet, and two birds from the SPI treatment died during the experiment. The other broilers remained healthy throughout the experiment.

\section{Crude protein content of experimental diets}

The CP content of the experimental diets containing the various protein sources ranged from $20.8 \%$ for the RSM and DPP diets to $21.4 \%$ for the SPI diet (DM basis) (Table 4.2), of which approximately $75 \%$ of the CP originated from the protein sources and the remaining $25 \%$ from the supplemented SBM.

Table 4.2. Analysed chemical and amino acid composition of the experimental diets.

\begin{tabular}{|c|c|c|c|c|c|c|c|}
\hline \multirow[b]{2}{*}{ Item $^{2}$} & \multicolumn{7}{|c|}{ Diets containing the various protein source ${ }^{1}$} \\
\hline & SBM & SPI & WG & RSM & DPP & BSF & Basal \\
\hline Dry matter (\% as-fed) & 90.1 & 90.9 & 90.4 & 90.4 & 89.2 & 91.6 & 88.8 \\
\hline Ash & 5.8 & 6.0 & 5.5 & 5.9 & 6.3 & 7.6 & 5.3 \\
\hline Crude protein & 21.0 & 21.4 & 21.1 & 20.8 & 20.8 & 21.1 & 5.2 \\
\hline Crude fat & 3.9 & 1.4 & 2.2 & 8.5 & 1.9 & 4.9 & 1.3 \\
\hline Starch & 27.4 & 42.4 & 42.4 & 16.1 & 39.6 & 32.3 & 51.6 \\
\hline Sugars & 17.7 & 15.0 & 15.8 & 19.2 & 15.5 & 14.9 & 15.1 \\
\hline \multicolumn{8}{|l|}{ Indispensable AA } \\
\hline His & 0.59 & 0.64 & 0.54 & 0.64 & 0.69 & 0.67 & - \\
\hline lle & 1.14 & 1.04 & 0.81 & 0.87 & 0.87 & 0.85 & - \\
\hline Leu & 1.59 & 1.72 & 1.38 & 1.49 & 1.73 & 1.35 & - \\
\hline Lys & 1.20 & 1.31 & 1.40 & 1.14 & 1.38 & 1.30 & - \\
\hline Met & 0.51 & 0.30 & 0.41 & 0.40 & 0.47 & 0.60 & - \\
\hline Phe & 1.03 & 1.12 & 0.89 & 0.86 & 1.01 & 0.90 & - \\
\hline Thr & 0.82 & 0.99 & 0.77 & 0.91 & 1.04 & 0.88 & - \\
\hline Val & 1.00 & 1.07 & 0.96 & 1.06 & 1.20 & 1.10 & - \\
\hline \multicolumn{8}{|l|}{ Dispensable AA } \\
\hline Ala & 0.91 & 0.95 & 0.60 & 0.92 & 1.03 & 1.20 & - \\
\hline Asx & 2.40 & 2.57 & 1.09 & 1.75 & 1.97 & 1.91 & - \\
\hline Cys & 0.28 & 0.27 & 0.37 & 0.41 & 0.63 & 0.18 & - \\
\hline Glx & 3.72 & 4.06 & 5.98 & 3.52 & 3.39 & 2.39 & - \\
\hline Gly & 0.88 & 0.91 & 0.69 & 1.02 & 0.91 & 0.93 & - \\
\hline Pro & 1.19 & 1.26 & 2.02 & 1.34 & 1.38 & 1.18 & - \\
\hline Ser & 1.07 & 1.14 & 0.97 & 0.96 & 1.09 & 0.83 & - \\
\hline
\end{tabular}




\section{Growth performance}

The initial body weight of broilers did not differ among treatment (Table 4.3). The ADG, ADFI and FCR were affected by the diet $(P<0.001)$. Broilers fed the RSM diet showed the highest ADFI and broilers fed the SPI diet the lowest (181.7 and $135.3 \mathrm{~g}$, respectively).

\section{Digestion kinetics of dry matter and crude protein along the SI}

The $A D_{D M}$ and $A D_{C P}$ increased along the SI for all diets $(P<0.001)$, mainly in between the duodenum and the distal jejunum (Table 4.4). The $A D_{\mathrm{DM}}$ along the $\mathrm{SI}$ was affected by the diet $(P<0.001)$. The SPI, WG and DPP diets showed a higher $\mathrm{AD}_{\mathrm{DM}}$ than the SBM and RSM diets in both jejunum segments and the ileum $(P<0.001)$. The $\mathrm{AD}_{\mathrm{CP}}$ along the SI was also affected by the diet $(P<0.001)$. In both jejunum segments, the WG diet showed the highest and the RSM diet the lowest $A D_{\text {cP. }}$ The $A D_{C P}$ in the ileum was higher for the SPI, WG and DPP diets than for the SBM, RSM and BSF diets $(P<0.001)$.

The retention time of the solid fraction ( $R T_{\text {solid }}$ ) of digesta differed among the GIT segments $(P<0.001)$ (Table 4.5). The averaged $\mathrm{RT}_{\text {solid }}$ from all diets in the crop, gizzard, duodenum, proximal jejunum, distal jejunum and ileum was $15 \pm 8,27 \pm 8,1 \pm 1$, $45 \pm 6,50 \pm 4,21 \pm 4$ min, respectively, with an estimated mean $\mathrm{RT}_{\text {solid }}$ over the entire $\mathrm{SI}$ of $122 \pm 16$ min (mean \pm standard deviation). The standard deviation of the RT solid mainly originated from the variation among dietary treatments rather than the variation within dietary treatments. The SPI diet had a lower $\mathrm{RT}_{\text {solid }}$ in the crop than the SBM and RSM diets $(P<0.01)$. The $\mathrm{RT}_{\text {solid }}$ in the gizzard was higher for the WG and DPP diets than for the RSM and BSF diets $(P<0.001)$. The $\mathrm{RT}_{\text {solid }}$ in the proximal jejunum, distal jejunum and ileum did not differ among the diets $(P>0.05)$. The retention time of the liquid fraction (RT liquid) of digesta also differed among the GIT segments $(P<0.001)$. The averaged $\mathrm{RT}_{\text {liquid }}$ from all diets in the crop, gizzard, proximal jejunum, distal jejunum and ileum was $17 \pm 9,16 \pm 2,42 \pm 7,44 \pm 5,23 \pm 6$ min, respectively, with an estimated mean RT over the entire SI of $107 \pm 15 \mathrm{~min}$. The duodenum digesta samples could not be analysed for $\mathrm{Cr}$ concentration due to the limited amount of digesta collected. The averaged $\mathrm{RT}_{\text {liquid }}$ in the duodenum, therefore, cannot be presented. Similar to the $\mathrm{RT}_{\text {solid, }}$ the standard deviation of the $\mathrm{RT}_{\text {liquid }}$ mainly originated from the variation among dietary treatments rather than the variation within dietary treatments. The $\mathrm{RT}_{\text {liquid }}$ in the crop was higher for the SBM and RSM diets than for the SPI and BSF diets $(P<0.001)$. The $\mathrm{RT}_{\text {liquid }}$ in the gizzard and distal jejunum did not differ among the diets $(P>0.05)$. The 
RSM diet had a higher $\mathrm{RT}_{\text {liquid }}$ in the ileum than the WG diet $(P<0.01)$. Over all experimental diets, the solid fraction of digesta showed a longer RT in the gizzard than the liquid fraction of digesta (27 and 16 min, respectively; $P<0.01$ ) and tended to show a longer RT in the SI (122 and 107 min, respectively; $P=0.052)$.

Large differences in DM and CP digestion rate constants were observed among diets (Table 4.6 and Figure 4.1). The DM digestion rate constant ranged from $0.026 \mathrm{~min}^{-1}$ for the RSM diet to $0.267 \mathrm{~min}^{-1}$ for the WG diet. The CP digestion rate constant ranged from $0.023 \mathrm{~min}^{-1}$ for the RSM diet to $0.365 \mathrm{~min}^{-1}$ for the SPI diet. The WG and SPI diets showed a high initial rate of protein digestion $\left(65\right.$ and $67 \mathrm{~g} \cdot \mathrm{min}^{-1}$ per $\mathrm{kg}$ diet, respectively) followed by the DPP diet $\left(17 \mathrm{~g} \cdot \mathrm{min}^{-1}\right.$ per $\mathrm{kg}$ diet $)$ and the SBM, RSM and BSF diets (7, 4 and $6 \mathrm{~g} \cdot \mathrm{min}^{-1}$ per $\mathrm{kg}$ diet, respectively). 


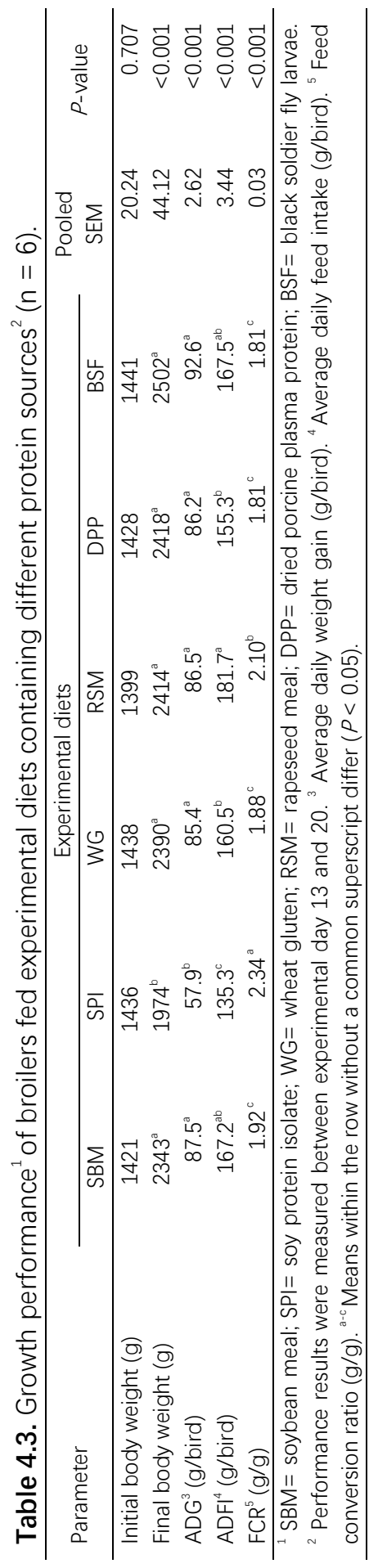




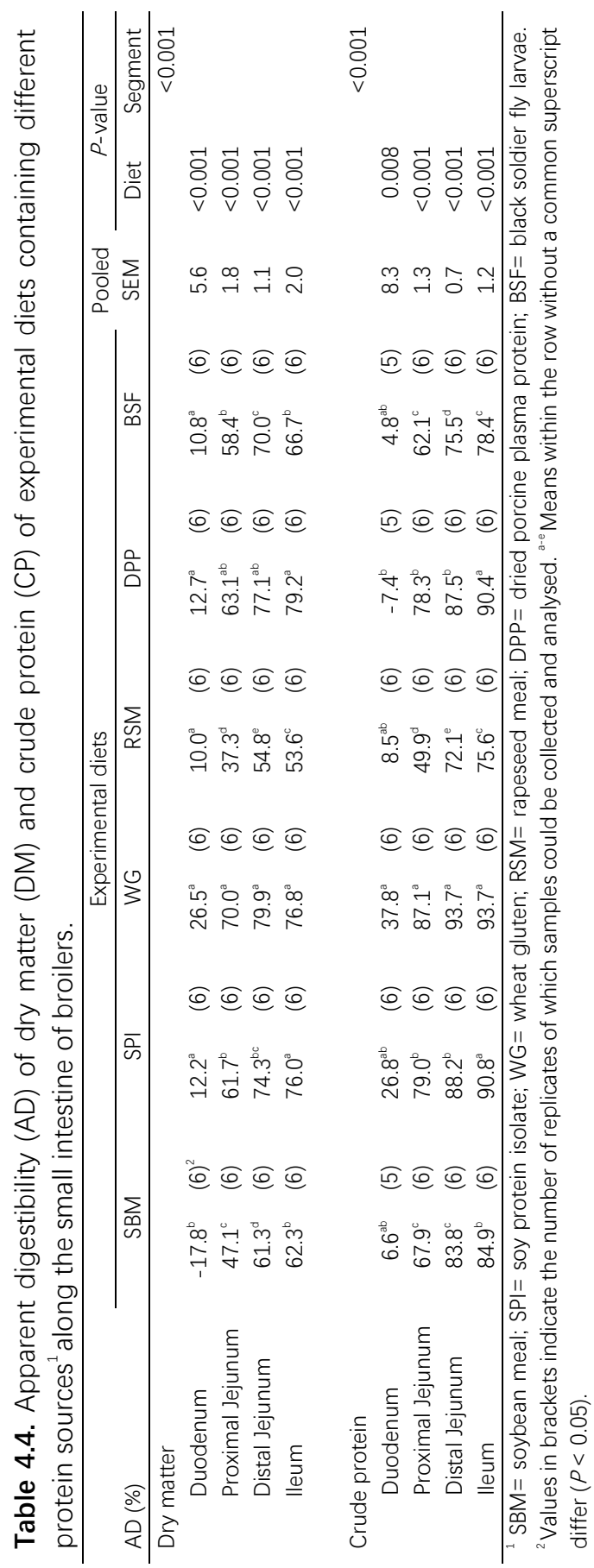




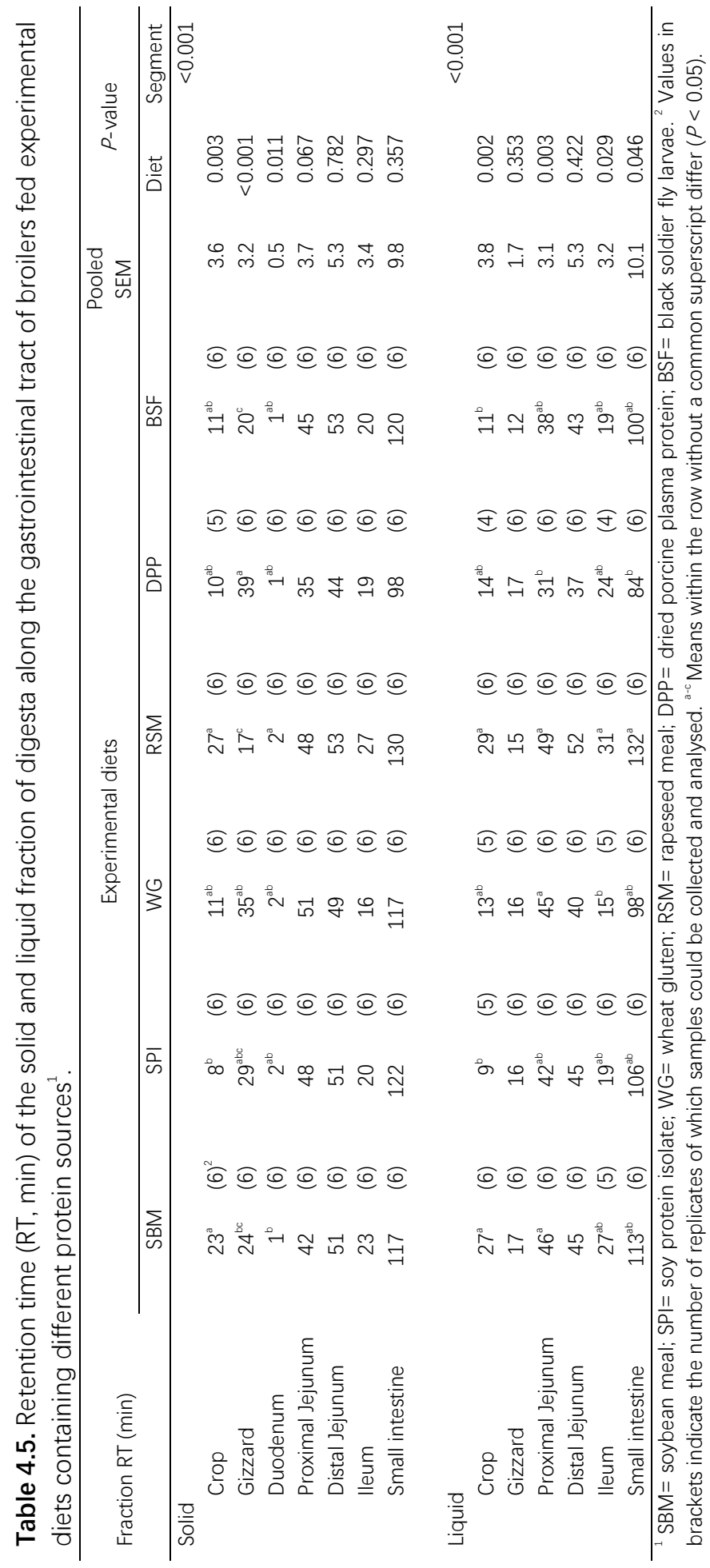




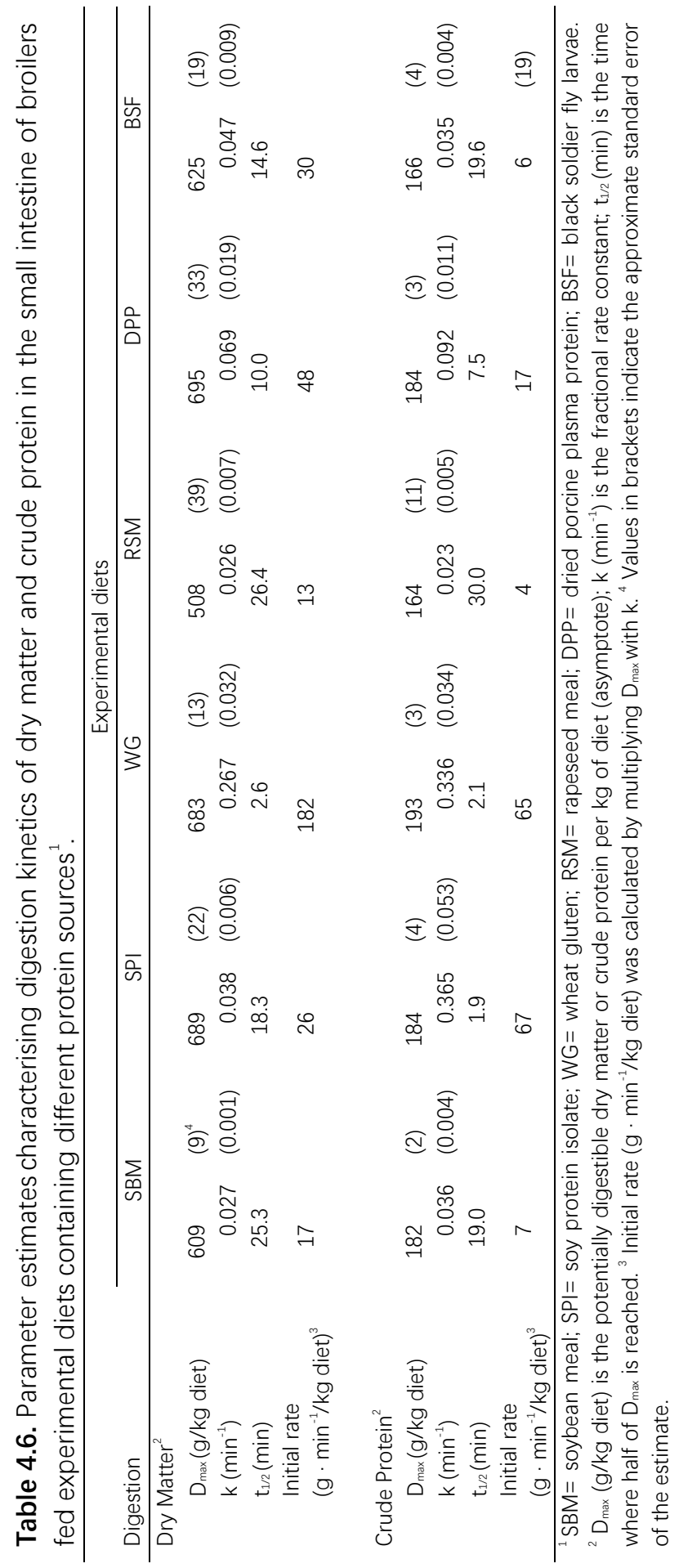




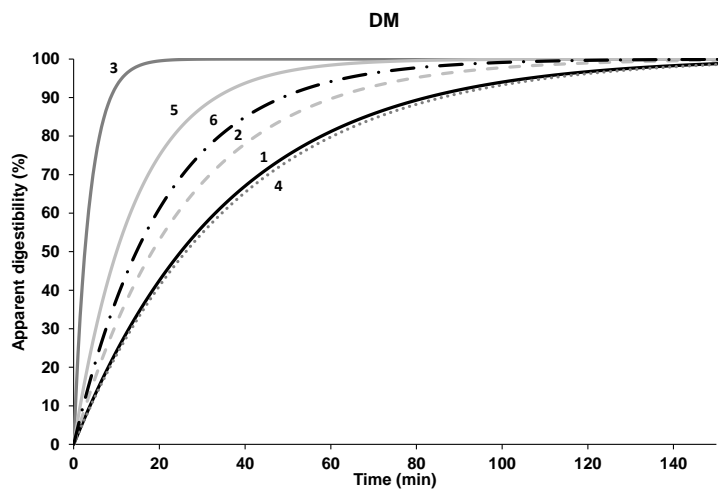

CP

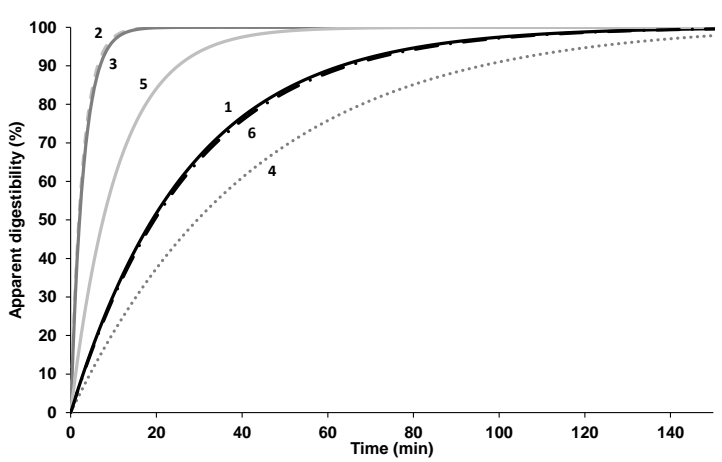

Figure 4.1. Rescaled digestion curves (setting $D_{\max }$ at $100 \%$ ) of dry matter (DM) and crude protein (CP) of experimental diets containing soybean mean (1), soy protein isolate (2), wheat gluten (3), rapeseed meal (4), dried porcine plasma protein (5) or black soldier fly larvae (6) as the main dietary protein source in the small intestine of broilers.

Molecular weight distribution of protein and peptides in digesta of the stomach and SI

Proteins and peptides in the diets predominantly had a molecular weight $>10 \mathrm{kDa}$ (Figure 4.2). Fewer peptides with a molecular weight $>10 \mathrm{kDa}$ were present in digesta of the SI than the diet. The molecular weight distribution of proteins and peptides in digesta over the SI was similar for each of the dietary treatments. The molecular weight fractions $>10 \mathrm{kDa}$ accounted for the majority of proteins and peptides in digesta of the SI. Values for the mass extinction coefficients of peptides $<1 \mathrm{kDa}$ were negative after the correction for the signals from the $2 \%$ SDS and $100 \mathrm{mM}$ dithiothreitol solution used for sample extraction. 

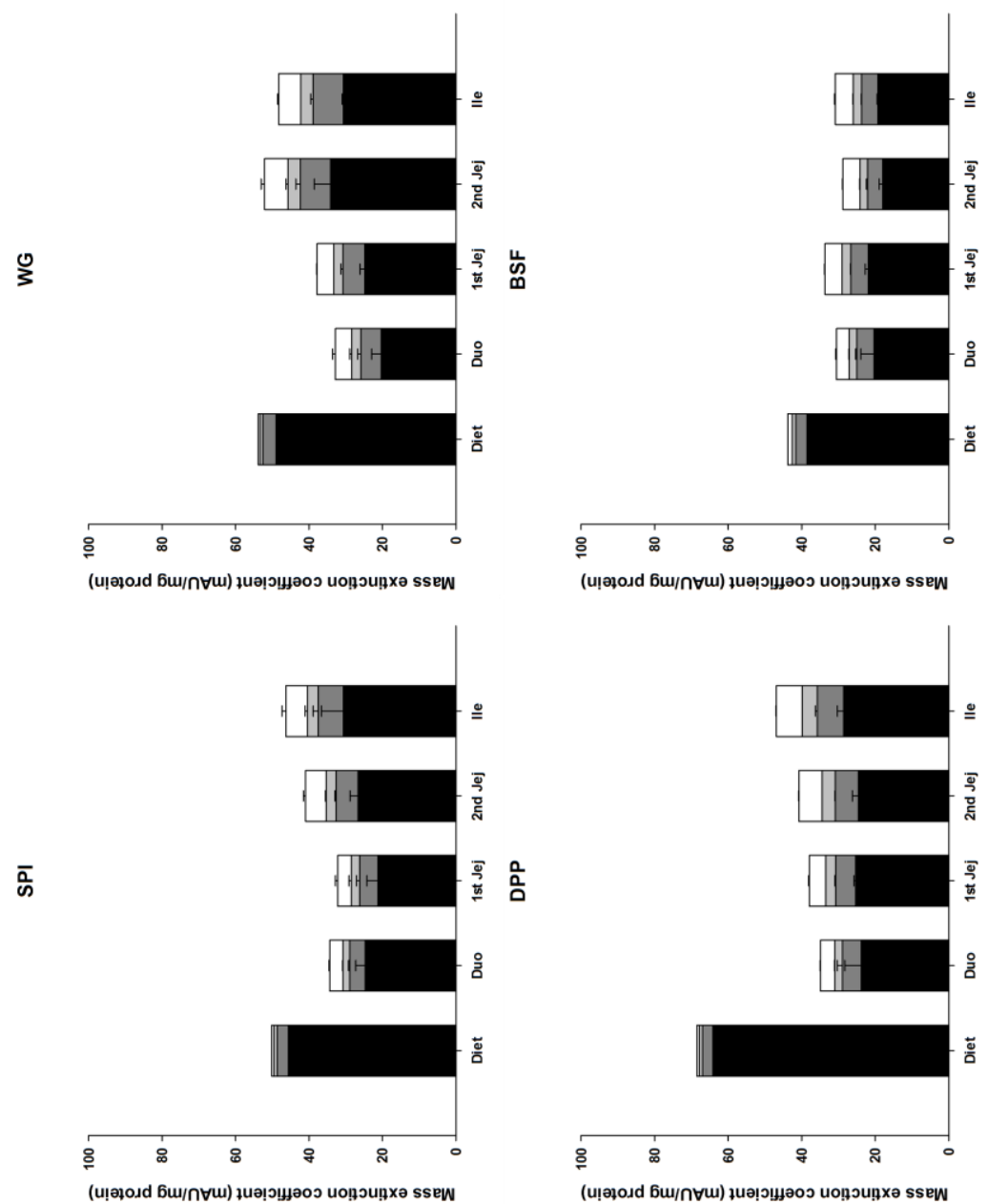

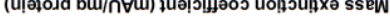
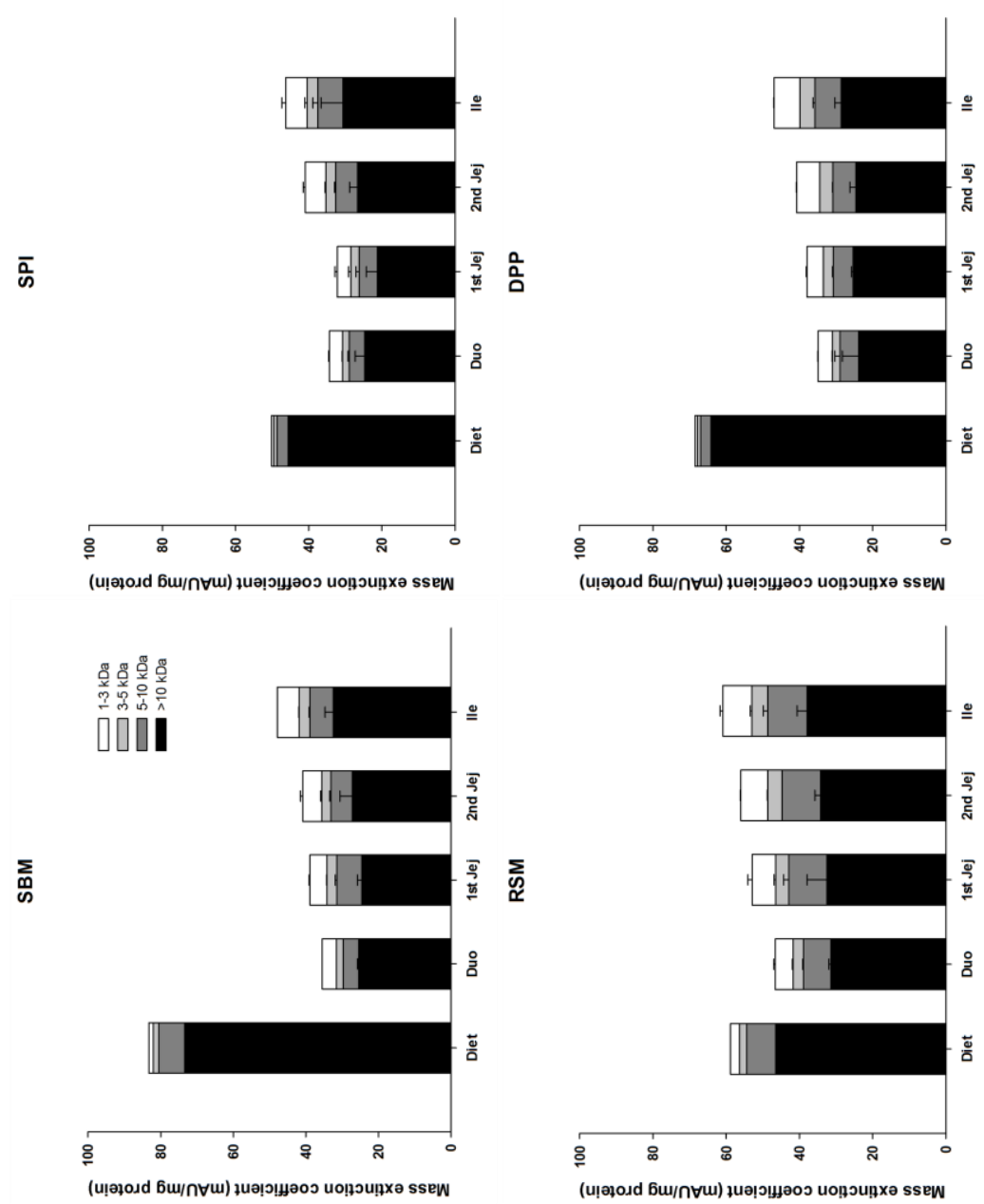

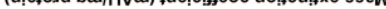

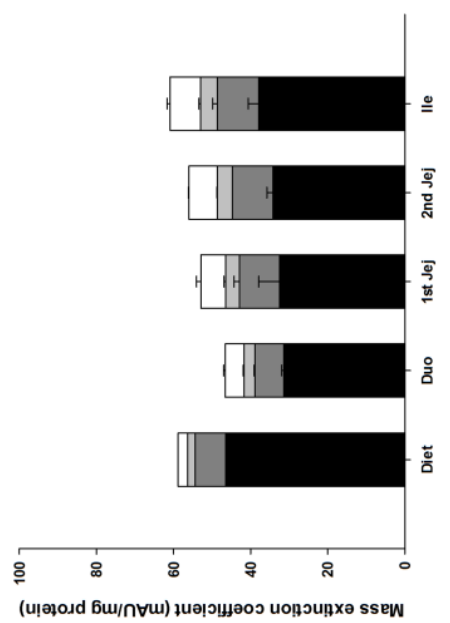




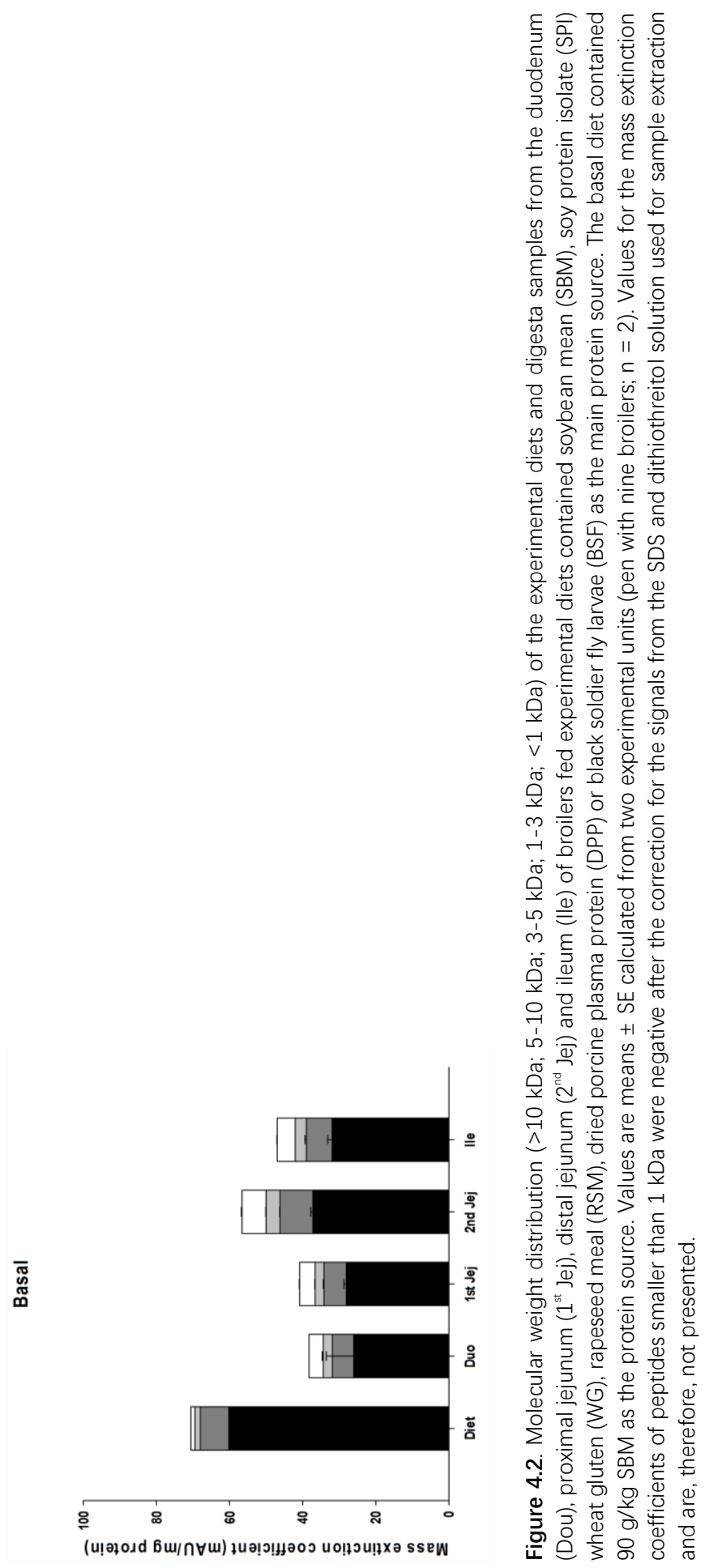




\section{DISCUSSSION}

The aim of the present study was to determine the in vivo protein digestion kinetics of diets with different protein sources up to the end of the SI of broilers. The protein digestion kinetics was calculated from the digesta retention time and protein digestibility, which is the result of protein hydrolysis and absorption. At the start of the study, the tested protein sources were included as a single protein source in the respective experimental diets with supplemented free AAs to the diets to prevent severe deficiencies in the supply of essential AAs (total AA supply in free form among diets ranging from 0 to $17.5 \mathrm{~g} / \mathrm{kg}$ diet). However, when feeding these diets, the birds on the SPI, WG and DPP diets showed a $20 \%$ lower feed intake than the birds on the SBM and RSM diets over experimental day 7 to 12. To avoid large differences in feed intake among experimental diets that could influence both digesta passage rate and nutrient digestibility, all diets were supplemented with the same level of SBM (100 g SBM per kg diet, on top of) and fed subsequently. However, a lower ADFI was still observed in broilers fed the SPI diet. The differences in protein digestion kinetics of the experimental diets, therefore, can still be attributed to differences in protein sources included in the experimental diets, which provided approximately $75 \%$ of the total amount of protein present in the diets. Among protein sources, SPI, WG and DPP had a higher CP content than the other protein sources. Since all experimental diets were formulated isoproteineous, the inclusion level of SPI, WG and DPP in the diets was lower than the other protein sources. Maize starch was used to fill up the gap of non-protein components present in SBM, RSM and BSF in the diets with SPI, WP and DPP, resulting in a higher starch content of these diets.

The $A D_{C p}$ of the diets was determined in the duodenum, proximal jejunum, distal jejunum and the ileum. The $A D_{c p}$ largely increased along the jejunum, with an average increase of $69 \pm 12 \%$ over all experimental diets. These results indicate that for broilers, dietary proteins from the evaluated protein sources were mainly hydrolysed and absorbed in the jejunum, especially the proximal jejunum. Values for the $A D_{\mathrm{cp}}$ measured in the ileum for the SBM and RSM diets (85 and $76 \%$, respectively) were comparable to published values (82 and $79 \%$, respectively) of apparent ileal protein digestibility of broilers in the literature (Ravindran et al., 2005). The SPI, WG and DPP diets showed a high $A D_{C P}$ up to the end of the ileum (91, 94 and $90 \%$, respectively). SPI, WG and DPP, therefore, can be considered as highly digestible protein sources. In contrast, the RSM and BSF diets showed a relative low $A D_{c p}$ up to the end of the ileum (76 and $78 \%$, respectively). 
It is generally assumed that proteins present in highly digestible protein sources are more susceptible to hydrolysis by digestive enzymes, whereas proteins present in low digestible protein sources are more resistant to enzymatic hydrolysis. As a consequence, relatively more low and intermediate molecular weight peptides were expected to be present in the ileal digesta of broilers fed highly digestible protein sources. In contrast, relatively more high molecular weight proteins and peptides were expected to be present in ileal digesta of broilers fed low digestible protein sources. The molecular weight distributions of proteins and peptides in digesta of the ileum, however, were comparable between highly and low digestible protein sources. In addition, the molecular weight distributions remained rather similar throughout segments of the GIT for all diets. These results indicate that proteins from both highly and low digestible sources follow a "one-by-one" type of hydrolysis mechanism (Adler-Nissen, 1976), meaning intact proteins are hydrolysed to low molecular weight peptides and free AAs and absorbed by the intestinal mucosa in one sequence. As a result, proteins and peptides with a wide range of molecular weights were not observed in digesta of different segments of the GIT. The factor limiting the extent of digestion of protein sources in the SI of broilers then could be related to the initial rate of hydrolysis, calculated from the amount of potentially digestible protein in the diet $\left(D_{\max }\right)$ and the digestion rate constant $(k)$ in the present study. Proteins present in highly digestible protein sources might show a higher initial hydrolysis rate than proteins present in low digestible protein sources. Nearly no peptides $<1 \mathrm{kDa}$ were found in digesta of the SI after the correction for the signals from the extraction solution. This is different from our previous study in pigs, in which approximately $30 \%$ of proteins and peptides in digesta of the SI were present in the molecular fraction $<1 \mathrm{kDa}$ (Chapter 3). The presence of fewer peptides $<1 \mathrm{kDa}$ in digesta of broilers might result from the occurrence of antiperistaltic contractions (i.e. digesta reflux) in the GIT of poultry (Duke, 1982). The reflux of digesta provides opportunity for further digestion and adsorption of nutrients (Basha and Duke, 1999).

The RT of the solid and liquid fraction of digesta along the GIT was measured using $\mathrm{TiO}_{2}$ and $\mathrm{Cr}$-EDTA, respectively. The liquid fraction of digesta showed a shorter RT in the gizzard than the solid phase of digesta, which agrees with the study of Vergara et al. (1989) who also measured the passage rate of digesta in the gizzard using both soluble and insoluble markers. Proteins, which are solubilised in the gizzard of broilers, therefore, are expected to be transported from the gizzard to the SI faster than proteins which are insoluble. As a result, they could be subjected to a more rapid 
enzymatic hydrolysis and absorption in the SI, leading to a rapid postprandial appearance of AAs in the portal circulation. The solid fraction of digesta tended to show a longer RT in the SI than the liquid fraction of digesta (122 and $107 \mathrm{~min}$, respectively; $P=0.052$ ). Similar results were found in a study with pigs, in which the RT in the small intestine of the solid fraction of digesta was, on average, 30 min longer than that of the liquid fraction (Wilfart et al., 2007). The estimated mean $\mathrm{RT}_{\text {solid }}$ Over the entire SI of broilers (122 $\pm 16 \mathrm{~min}$ ) was lower than published data in the literature, which was between 140 to 180 min (Weurding et al., 2001; Liu et al., 2013). This is likely due to the use to semi-purified diets in the present study. Broilers fed semi-purified diets showed an 8 \% lower RT of digesta along the GIT than cereal-based diets (Rochell et al., 2012). A relatively low $\mathrm{RT}_{\text {solid }}$ in the ileum for all experimental diets was observed. The AD the digestion of nutrients in the diets is nearly completed at the end of the jejunum. This might explain the short $\mathrm{RT}_{\text {solid }}$ in the ileum.

Studies on digestion kinetics of nutrients commonly provide information on the potentially digestible fraction $\left(D_{\max }\right)$ and the digestion rate constant $(k)$. The rate constant of the digestion of nutrients is independent of size of the potential digestible fraction. In quantitative nutrition studies, comparison of parameters accounting for both the rate constant and the size of the potentially digestible fraction is preferred over comparison of the rate constant only. Therefore, the initial rate $\left(\mathrm{g} \cdot \mathrm{min}^{-1}\right.$ per $\mathrm{kg}$ diet), calculated by multiplying the potentially digestible fraction and the rate constant, was used to compare the digestion kinetics of the experimental diets. With respect to crude protein digestion, the SPI and WG diets showed the highest initial rate and the RSM diet the lowest. Although the DPP diet showed a similar $A D_{c P}$ in the ileum to the SPI and WG diet, the initial rate was 3.8 times lower than that of the SPI and WG diet (17 vs. 67 and $65 \mathrm{~g} \cdot \mathrm{min}^{-1}$ per $\mathrm{kg}$ diet). These results indicate that protein sources with a similar ileal protein digestibility can differ in protein digestion kinetics up to the end of the SI in broilers. Over the six experimental diets, no correlation was found between the initial rate of protein digestion in the $\mathrm{SI}$ and the $\mathrm{AD}_{\mathrm{cp}}$ up to the ileum $(P=0.20)$. This opposes the hypothesis that highly digestible protein sources are digested faster than less digestible sources in the SI of broilers.

Protein sources with a high CP content (i.e. SPI, WG and DPP), on average, showed a faster digestion kinetics than protein sources with a relatively low CP content (i.e. SBM, RSM and BSF). Similar results were found in pig studies when feeding soy protein concentrate and a mixture of untoasted and toasted SBM. Pigs fed soy protein 
concentrate showed a more rapid postprandial portal appearance of AAs than pigs fed a mixture of untoasted and toasted soybean meal after meal ingestion (Jansman et al., 1997). This is likely due to the negative effects of non-protein constituents present in less purified protein sources on protein digestion. Soybean meal and RSM consist for 20-30\% non-starch polysaccharides (NSP) (CVB, 2016), which can be further divided into insoluble NSP (i.e. mainly cellulose) and soluble NSP. In broilers, an increase in soluble NSP content in the diet results in a decreased absorption of nutrients in the SI (Antoniou et al., 1981; Choct and Annison, 1990). This is likely due to the fact that soluble NSP can increase the viscosity of digesta (Bach Knudsen, 2001). Moreover, other anti-nutritional factors present in SBM (e.g. protease inhibitors, lectins) (Campbell and van der Poel, 1998) and RSM (e.g. sinapine, phytic acid, tannins) (Khajali and Slominski, 2012) could also hinder protein digestion in the SI of broilers.

In broiler diets, energy is mainly provided in the form of starch by cereal grains such as wheat, maize and barley, and proteins mainly by vegetable proteins such as SBM and RSM. In the SI of broilers, the average digestion rate constant of starch of these cereal grains was $0.045 \pm 0.005 \mathrm{~min}^{-1}$ (Weurding et al., 2001). This value is $20 \%$ higher than the digestion rate constant of protein from SBM and RSM as reported in the present study. This suggests that starch from cereal grains is digested faster than most dietary proteins in broiler diets, resulting in some degree of asynchrony in availability of AAs and glucose in the post-absorption metabolism in broilers. As a consequence, more AAs are likely to be oxidised to produce energy. This could explain why feeding slowly digestible starch or fast digestible proteins to broilers is beneficial for their growth performance (Weurding et al., 2003; Frikha et al., 2014).

Broilers have a shorter SI than pigs. The RT of the digesta is lower in the SI of broilers than of pigs (Weurding et al., 2001; Wilfart et al., 2007). Broilers, however, show a comparable ileal protein digestibility of most feed ingredients compared to pigs (Lemme et al., 2004). This could be due to a higher rate of hydrolysis and absorption of dietary proteins and AAs in the SI of broilers. In our previous study, the kinetics of protein digestion of the same protein sources as used in the present study were determined in the $\mathrm{SI}$ of pigs. Indeed, the fractional protein digestion rate of these protein sources was, on average, 2.7 times higher in broilers than in pigs (Chapter 3). Despite the differences in digestion between species, the ranking of the protein sources in terms of protein digestion kinetics were comparable in both species. 


\section{CONCLUSIONS}

The kinetics of protein digestion differed among protein sources in the small intestine of broilers. Soy protein isolate, WG and DPP can be regarded as fast digestible while SBM, RSM and BSF as more slowly digestible protein sources. Purified protein sources (i.e. high in protein content) tend to be digested faster in the small intestine of broilers than less purified protein sources due to the negative effects on protein digestion of non-protein constituents such as fibre present in less purified protein sources.

\section{ACKOWLEDGEMENTS}

The authors gratefully acknowledge the financial support from the Wageningen UR "IPOP Customized Nutrition" programme financed by Wageningen UR (Wageningen, the Netherlands), the Dutch Ministry of Economic Affairs, Agriculture \& Innovation (the Hague, the Netherlands), WIAS graduate school (Wageningen, the Netherlands), Nutreco (Boxmeer, the Netherlands) and Darling Ingredients International (Irving, TX, USA). 


\section{REFERENCES}

Adler-Nissen, J. 1976. Enzymic hydrolysis of proteins for increased solubility. J. Agric. Food Chem. 24:1090 1093.

Antoniou, T., and R. R. Marquardt. 1981. Influence of rye pentosans on the growth of chicks. Poult. Sci. 60:1898-1904.

Basha, M. E., and G. E. Duke. 1999. Effect of fasting on small intestinal antiperistalsis in the Nicholas turkey (Meleagris gallopavo). J. Exp. Zool. Part A: Ecol. Genet. Physiol. 283:469-477.

Campbell, G. L., and A. F. B. van der Poel. 1998. Use of enzymes and process technology to inactivate antinutritional factors in legume seeds and rapeseed. Proc. 3rd Int. ANF Workshop Recent Advances of Research in Antinutritional Factors in Llegume Seeds and Rapeseed. A.J.M. Jansman et al. (eds.). EAAP Publication, 93; 377-386, Wageningen, the Netherlands.

Choct, M., and G. Annison. 1990. Anti-nutritive activity of wheat pentosans in broiler diets. Br. Poult. Sci. 32:811-821.

CVB, 2009. Feeding standards, feeding advices and nutritional values of feeding ingredients of poultry. Centraal Veevoeder Bureau, Wageningen, the Netherlands

CVB, 2016. Chemical compositions and nutritional values of feed ingredients. Centraal Veevoeder Bureau, Wageningen, the Netherlands

De Marco, M., S. Martínez, F. Hernandez, J. Madrid, F. Gai, L. Rotolo, M. Belforti, D. Bergero, H. Katz, and S. Dabbou. 2015. Nutritional value of two insect larval meals (Tenebrio molitor and Hermetia illucens) for broiler chickens: Apparent nutrient digestibility, apparent ileal amino acid digestibility and apparent metabolizable energy. Anim. Feed Sci. Technol. 209:211-218.

Duke, G. E. 1982. Gastrointestinal motility and its regulation. Poult. Sci. 61:1245-1256.

Frikha, M., M. Mohiti-Asli, C. Chetrit, and G. G. Mateos. 2014. Hydrolysed porcine mucosa in broiler diets: effects on growth performance, nutrient retention, and histomorphology of the small intestine. Poult. Sci. 93:400-411.

Geiger, E. 1950. The role of the time factor in protein synthesis. Science 111:594-599.

ISO. 1999a. ISO 6492:1999. Animal feeding stuffs-Determination of fat content. International Organization for Standardization, Geneva, Switzerland.

ISO. 1999b. ISO 6496:1999. Animal feeding stuffs-Determination of moisture and other volatile matter content. International Organization for Standardization, Geneva, Switzerland.

ISO. 2002. ISO 5984:2002. Animal feeding stuffs-Determination of crude ash content. International Organization for Standardization, Geneva, Switzerland.

ISO. 2004. ISO 15914-1:2004. Animal feeding stuffs-Enzymatic determination of total starch content. International Organization for Standardization, Geneva, Switzerland.

ISO. 2005a. ISO 5983-1:2005. Animal feeding stuffs-Determination of N content and calculation of crude protein content-Part 1: Kjeldahl method. International Organization for Standardization, Geneva, Switzerland.

ISO. 2005b. ISO 5983-1:2005. Animal feeding stuffs-Determination of amino acid content. International Organization for Standardization, Geneva, Switzerland.

ISO. 2008. ISO 16634-1:2008. Food products-Determination of the total $\mathrm{N}$ content by combustion according to the Dumas principle and calculation of the crude protein content-Part 1: Oilseeds and animal feeding stuffs. International Organization for Standardization, Geneva, Switzerland.

Jansman, A. J. M., H. Enting, M. W. A. Verstegen, and J. Huisman. 1994. Effect of condensed tannins in hulls of faba beans (Vicia faba L.) on the activities of trypsin (EC 2.4. 21.4) and chymotrypsin (EC 2.4. 21.1) in digesta collected from the small intestine of pigs. Br. J. Nutr. 71:627-641.

Khajali, F., and B. A. Slominski. 2012. Factors that affect the nutritive value of canola meal for poultry. Poult. Sci. 91:2564-2575.

Knudsen, K. E. B. 2001. The nutritional significance of dietary fibre analysis. Anim. Feed Sci. Technol. 90:3-20.

Lemme, A., V. Ravindran, and W. L. Bryden. 2004. Ileal digestibility of amino acids in feed ingredients for broilers. Worlds. Poult. Sci. J. 60:423-438. 
Liu, S. Y., P. H. Selle, and A. J. Cowieson. 2013. The kinetics of starch and nitrogen digestion regulate growth performance and nutrient utilisation of broilers fed coarsely ground, sorghum-based diets. Anim. Prod. Sci. 53:1033-1040.

Liu, S. Y., and P. H. Selle. 2015. A consideration of starch and protein digestive dynamics in chicken-meat production. Worlds. Poult. Sci. J. 71:297-310.

Malabat, C., and C. Rabiller. 2001. Emulsifying and foaming properties of native and chemically modified peptides from the $2 \mathrm{~S}$ and $12 \mathrm{~S}$ proteins of rapeseed (Brassica napus L.). J. Am. Oil Chem. 78:235-242.

Mojica, L., K. Chen, and E. G. Mejía. 2015. Impact of commercial precooking of common bean (Phaseolus vulgaris) on the generation of peptides, after pepsin-pancreatin hydrolysis, capable to inhibit dipeptidyl peptidase-IV. J. Food Sci. 80:H188-H198.

Myers, W. D., P. A. Ludden, V. Nayigihugu, and B. W. Hess. 2004. Technical note: a procedure for the preparation and quantitative analysis of samples for titanium dioxide. J. Anim. Sci. 82:179-183.

Ørskov, E. R., and I. McDonald. 1979. The estimation of protein degradability in the rumen from incubation measurements weighted according to rate of passage. J. Agric. Sci. 92:499-503.

Ravindran, V., L. I. Hew, G. Ravindran, and W. L. Bryden. 2005. Apparent ileal digestibility of amino acids in dietary ingredients for broiler chickens. Anim. Sci. 81:85-97.

Recoules, E., H. Sabboh-Jourdan, A. Narcy, M. Lessire, G. Harichaux, V. Labas, M. J. Duclos, and S. RéhaultGodbert. 2017. Exploring the in vivo digestion of plant proteins in broiler chickens. Poult. Sci. 96:17351747

Rochell, S. J., T. J. Applegate, E. J. Kim, and W. A. Dozier. 2012. Effects of diet type and ingredient composition on rate of passage and apparent ileal amino acid digestibility in broiler chicks. Poult. Sci. 91:16471653.

Selle, P. H., A. J. Cowieson, N. P. Cowieson, and V. Ravindran. 2012. Protein-phytate interactions in pig and poultry nutrition: a reappraisal. Nutr. Res. Rev. 25:1-17.

Stevens, B. R. 1992. Amino acid transport in intestine. Mammalian Amino Acid Transport, Springer, USA. pp. 149-163.

Tonheim, S. K., A. Nordgreen, I. Høgøy, K. Hamre, and I. Rønnestad. 2007. In vitro digestibility of watersoluble and water-insoluble protein fractions of some common fish larval feeds and feed ingredients. Aquaculture 262:426-435.

van Bussel, W., F. Kerkhof, T. van Kessel, H. Lamers, D. Nous, H. Verdonk, B. Verhoeven, N. Boer, and H. Toonen. 2010. Accurate determination of titanium as titanium dioxide for limited sample size digestibility studies of feed and food matrices by inductively coupled plasma optical emission spectrometry with real-time simultaneous internal standardization. At. Spectrosc. 31:81-88.

van den Borne, J. J. G. C., J. W. Schrama, M. J. W. Heetkamp, M. W. A. Verstegen, and W. J. J. Gerrits. 2007. Synchronising the availability of amino acids and glucose increases protein retention in pigs. Animal 1:666-674.

van Krimpen, M. M., R. P. Kwakkel, C. M. C. van der Peet-Schwering, L. A. den Hartog, and M. W. A. Verstegen. 2011. Effects of dietary energy concentration, nonstarch polysaccharide concentration, and particle sizes of nonstarch polysaccharides on digesta mean retention time and gut development in laying hens. Br. Poult. Sci. 52:730-741.

Veldkamp, T., G. van Duinkerken, A. van Huis, C. M. M. Lakemond, E. Ottevanger, G. Bosch, and T. van Boekel. 2012. Insects as a sustainable feed ingredient in pig and poultry diets: a feasibility study, Wageningen UR Livestock Research, Wageningen, the Netherlands.

Vergara, P., M. Jimenez, C. Ferrando, E. Fernandez, and E. Gonalons. 1989. Age influence on digestive transit time of particulate and soluble markers in broiler chickens. Poult. Sci. 68:185-189.

Weurding, R. E. 2002. Kinetics of starch digestion and performance of broiler chickens. PhD thesis. Wageningen University \& Reaseach, Wageningen, the Netherlands.

Weurding, R. E., A. Veldman, W. A. G. Veen, P. J. van der Aar, and M. W. A. Verstegen. 2001. Starch digestion rate in the small intestine of broiler chickens differs among feedstuffs. J. Nutr. 131:2329-2335.

Weurding, R. E., H. Enting, and M. W. A. Verstegen. 2003. The effect of site of starch digestion on performance of broiler chickens. Anim. Feed Sci. Technol. 110:175-184. 
Wilfart, A., L. Montagne, H. Simmins, J. Noblet, and J. van Milgen. 2007. Digesta transit in different segments of the gastrointestinal tract of pigs as affected by insoluble fibre supplied by wheat bran. Br. J. Nutr. 98:54-62.

Williams, C. H., D. J. David, and O. lismaa. 1962. The determination of chromic oxide in faeces samples by atomic absorption spectrophotometry. J. Agric. Sci. 59:381-385. 
$104 \mid P$ a g e 
Chapter 5

Effect of synchronising the kinetics of protein and starch digestion in the small intestine on the growth performance and carcass characteristics in broilers

H. Chen ${ }^{\star}$, J. de los Mozos Garcia ${ }^{\S}$, P.A. Wierenga ${ }^{\dagger}$, W.H. Hendriks ${ }^{\star}$, A.J.M. Jansman ${ }^{\ddagger}$

*Animal Nutrition Group, Wageningen University \& Research, The Netherlands

${ }^{\S}$ Trouw Nutrition, Nutreco, Spain

${ }^{\dagger}$ Laboratory of Food Chemistry, Wageningen University \& Research, The Netherlands

${ }^{\ddagger}$ Wageningen Livestock Research, The Netherlands 


\section{ABSTRACT}

The objective of the present study was to determine if synchronising the digestion kinetics of dietary starch and protein affects the growth performance and carcass characteristics in broilers. Four diets were evaluated in a $2 \times 2$ factorial design using pea (PS) and rice starch (RS) as a slow and fast digestible starch source, and soybean meal (SBM) and soy protein isolate (SPI) as a slow and fast digestible protein source, respectively. In addition, the experimental diets were also evaluated in a digestibility study with 300 birds in which the ileal digestibility of dry matter (DM), starch and crude protein $(C P)$ and nitrogen-corrected apparent metabolisable energy $\left(\mathrm{AME}_{n}\right)$ were determined. In the growth performance trial, a total of 800 one-day-old male broilers were used to determine average daily feed intake (ADFI), average body weight gain (ADG), feed conversion ratio (FCR) and energy conversion ratio (ECR) over day 7 - 35 . Broilers fed RS diets showed a $10 \%$ higher AIDstarch than broilers fed PS diets, leading to a higher $\mathrm{AME}_{n}$ of RS diets $(P<0.001)$ compared to PS diets. The ADFI was affected by the dietary starch and protein source $(P<0.001)$, with values ranging from $98.0 \mathrm{~g} / \mathrm{d}$ for birds on the PS-SBM diet to $81.4 \mathrm{~g} / \mathrm{d}$ when fed on the RS-SPI diet. Over the entire experimental period, birds fed the PS-SBM (slow - slow) diet showed the highest ADG $(62.6 \mathrm{~g})$ while birds on the RS-SPI (fast - fast) diet the lowest ADG (48.6 g; P < 0.001). Broilers on SPI diets showed higher carcass, breast meat and abdominal fat yields (\% of slaughter weight; $P<0.001)$ compared to birds on SBM diets $(P<0.001)$. In conclusion, broilers fed synchronised diets for starch and protein digestion kinetics did not show a higher growth performance and breast meat yield compared to birds fed asynchronized diets. 


\section{INTRODUCTION}

Starch and protein are two major constituents in commercial broiler diets. Starch is mainly provided by cereal grains such as wheat, maize and barley, and protein mainly by vegetable proteins such as soybean meal (SBM) and rapeseed meal, apart from the protein fraction originating from cereal grains. The kinetics of starch and protein digestion could affect the appearance of glucose and amino acids (AAs) in blood after meal ingestion (Adeleye et al., 2016). In pigs, fast digestible starch sources, such as maize starch, showed a more pronounced but transient postprandial appearance of glucose and insulin in blood than slowly digestible starch sources, such as pea starch (van der Meulen et al., 1997). Similarly, fast digestible protein sources showed an earlier and higher postprandial appearance of AAs in blood than slowly digestible sources in pigs (Barbé et al., 2014). In chickens, starch hydrolysis and glucose absorption mainly take place in the duodenum and the proximal jejunum (Riesenfeld et al., 1980), whereas protein hydrolysis and AAs absorption mainly occur in the jejunum and ileum (Sklan and Hurwitz, 1980). This indicates that there might be asynchrony in the digestion of dietary starch and protein in the small intestine (SI) of broilers. Indeed, previous studies showed that the digestion rate of starch of cereal grains was on average approximately $20 \%$ higher than the digestion rate of protein from SBM and rapeseed meal (Weurding et al., 2001; Chapter 4).

Digestible AAs provided via the diet are used by organs and tissues, either or not after transformation into other AAs, to synthesise proteins or as an energy source after deamination. An efficient utilisation of AAs for body protein deposition is economically important in modern-day broiler production. The simultaneous availability of AAs and glucose in organs and tissues increase protein deposition in growing animals (van den Borne et al., 2007). This indicates that a synchronised supply of glucose and AAs in organs and tissues is important for an efficient utilisation of dietary protein for body protein deposition. As starch might, on average, be digested faster than protein in broiler diets, glucose might show a faster postprandial appearance in blood than AAs. This might lead to an asynchrony in the supply of glucose and AAs in organs and tissues. It has been shown that feeding slowly digestible starch to broilers could increase body weight gain up to $5 \%$ and decreased feed conversion ratio by approximately $2 \%$ (Weurding et al., 2003). In addition, nitrogen retention was negatively correlated to the starch digestion rate in broilers fed sorghum-based diets, indicating slowly digestible starch benefited protein retention in broilers (Liu et al., 2013b). The former can probably 
be explained by the release of glucose in the distal part of the SI from slowly digestible starch, thereby sparing AAs from being catabolised to produce energy in the intestinal mucosa of the distal SI, and increasing their quantitative appearance in the portal circulation (van der Meulen et al., 1997; Li et al., 2008).

The objective of the present study was to determine if synchronising the digestion kinetics of dietary starch and protein affects the growth performance and carcass characteristics in broilers. It was hypothesised that feeding diets synchronised for digestion rate of dietary starch and protein to broilers 1) improves the growth performance, and 2) increases carcass and breast meat yield and decrease abdominal fat yield.

\section{MATERIALS AND METHODS}

\section{Experimental design}

Two experiments were performed: a digestibility trial and a growth performance trial. The digestibility trial followed a randomized complete block design. Four experimental diets ( $2 \times 2$ factorial arrangement) were used. Cages were blocked on the location in the experimental room (five blocks per room, four cages per block) and pens within a block were randomly allocated to one of the four experimental diets. With respect to the growth performance trial, the experiment followed a randomized complete block design, in which pens were blocked on the location in the experimental room (ten blocks, four pens per block). Pens within a block were randomly allocated to one of the four experimental diets.

\section{Protein sources and experimental diets}

In a $2 \times 2$ factorial arrangement, diets including both starch and protein sources with different digestion rates were compared. Rice starch (RS) (obtained from Beneo-Remy NV, Leuven-Wijgmaal, Belgium) was used as a fast digestible starch source and pea starch (PS) (Cosucra Group Warcoing, Warcoing, Belgium) as a slowly digestible starch source. Soy protein isolate (SPI) (obtained from Archer Daniels Midland Company, Chicago, IL, USA) was used as a fast digestible protein source and soybean meal (SBM) (commodity batch obtained via Trouw Nutrition, Casarrubios del Monte, Spain) as a slowly digestible protein source. The digestion rates of starch and protein of the starch and protein sources derived from literature and Chapter 4 (Table 5.1). 
Table 5.1. Estimated starch and protein digestion rates of starch and protein sources used in the present study.

\begin{tabular}{lccc}
\hline Ingredient & $\begin{array}{c}\text { Digestion rate } \\
\left(\% \cdot \mathrm{min}^{-1}\right)^{1}\end{array}$ & Species & Reference \\
Starch source & 0.65 & Pig & van Kempen et al., 2010 \\
$\begin{array}{l}\text { Rice starch } \\
\text { Pea starch }\end{array}$ & 0.34 & Pig & \\
& & & \\
$\begin{array}{l}\text { Protein source } \\
\text { Soy protein isolate }\end{array}$ & 32.3 & Broiler chicken & Chapter 4 \\
Soybean meal & 3.1 & Broiler chicken & \\
${ }^{1}$ Starch digestion rate was determined as the maximum rate of net portal glucose appearance using a \\
modified Michaelis-Menten enzyme kinetics model.
\end{tabular}

All four diets were formulated to be equal in metabolisable energy (ME) and not limiting in digestible essential AAs (CVB, 2009). In a previous study, broilers fed a diet with SPI as a single protein source showed a substantially lower feed intake than broilers fed a diet with SBM as the only protein source. The difference in feed intake, however, was reduced when supplementing the SPI diet with $100 \mathrm{~g}$ SBM per kg diet (Chapter 4). To limit differences in feed intake between birds of the different experimental treatments in the present study, $100 \mathrm{~g} / \mathrm{kg}$ SBM was included in all experimental diets. Soy fibre was included in the SPI diets ( 77 and $79 \mathrm{~g} / \mathrm{kg}$ in the grower and finisher diets) to reconstitute the fibre fraction coming from the SBM in the SBM diets. In the diets used in the digestibility experiment, titanium dioxide $\left(\mathrm{TiO}_{2}\right)$ was included as an indigestible marker at $2.5 \mathrm{~g} / \mathrm{kg}$ diet (as-fed basis). All diets were produced by Trouw Nutrition (Casarrubios del Monte, Spain). The ingredient, calculated and analysed nutrient composition of the experimental diets is presented in Table 5.2. 


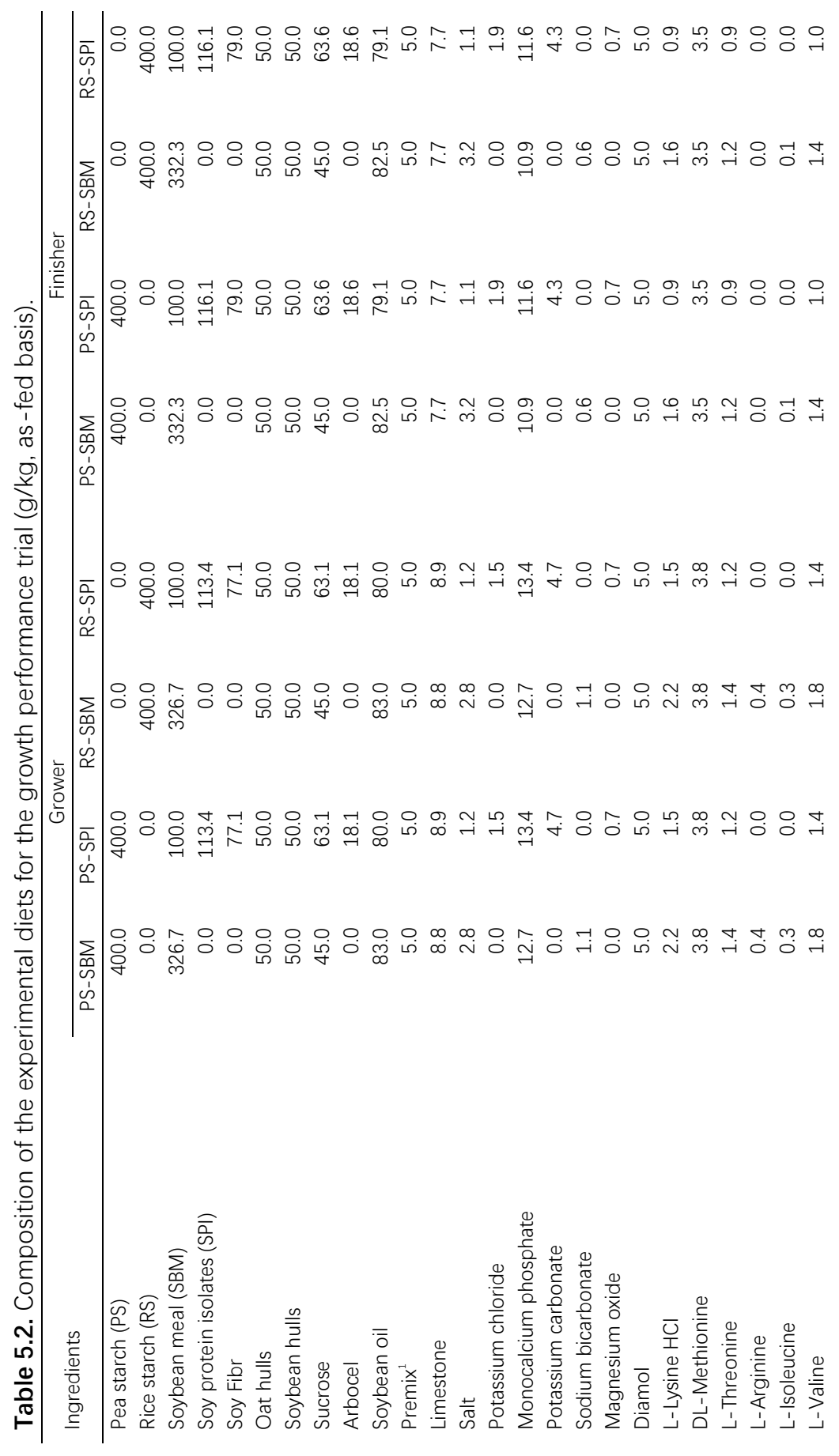




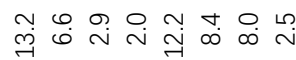

mॄษ

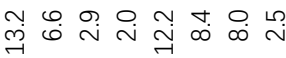

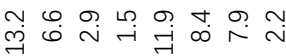

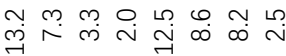

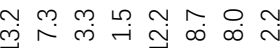

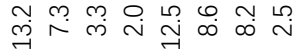

$\sim m m L N N O N$

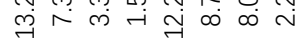

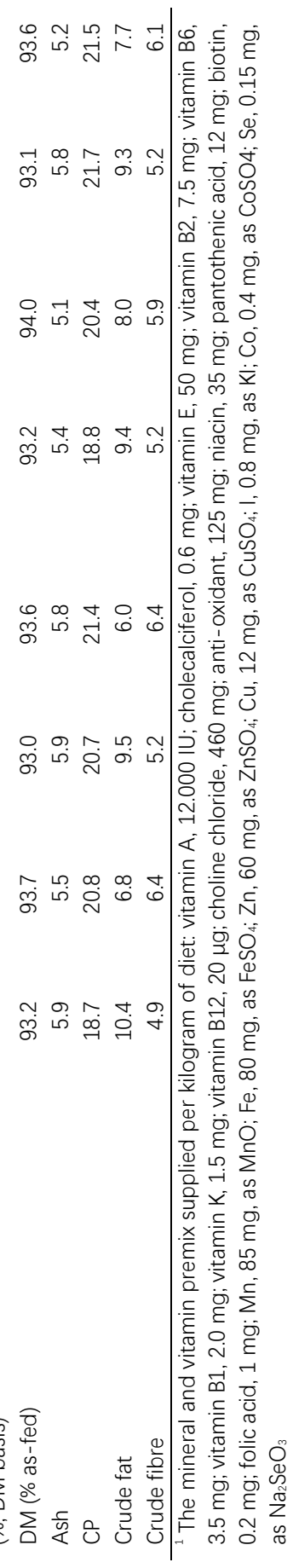




\section{Exp 1. Digestibility trial}

\section{Animals, housing and feeding}

A total of 300 one-day-old male broilers (Ross 308, Aviagen Group, Newbridge, UK) were used. From experimental day 1 to 14, broilers were housed in four floor pens with 75 birds in each pen. Pens were randomly allocated to one of the four experimental diets. From day 15, 60 out 75 broilers were selected from each pen and housed in 40 digestibility cages with six broilers in each cage. During the first two days, lights were continuously on (24L : OD). From day 3 onwards, the lighting schedule followed a fourcycle $2 \mathrm{~L}: 4 \mathrm{D}$ regime. From day 1 to 7 , broilers were fed a commercial diet and from day 7 onwards were fed only the experimental diets containing the indigestible marker. The experimental diets were provided in mash form and broilers had unlimited access to feed an water throughout the entire experiment.

\section{Data collection and calculation}

From day 21 to 23, excreta were collected twice a day, every morning and afternoon. Excreta samples obtained over three days of collection were pooled per cage and stored at $-20{ }^{\circ} \mathrm{C}$. Excreta samples from the same treatment in the same block of two experimental rooms were pooled to have sufficient sample for the planned chemical analyses. Samples were freeze-dried before dry matter (DM), gross energy, nitrogen, uric acid and $\mathrm{Ti}$ analysis to calculate total tract digestibility of DM and crude protein $(\mathrm{CP})$, and nitrogen-corrected apparent metabolisable energy ( $\mathrm{AME}_{n}$ ). At day 24, broilers were euthanized by an intravenous T-61 injection. The broilers were placed on their posterior side and the body cavity was opened prior to careful removal of the GIT from the crop to the cloaca. The GIT was carefully located horizontally on the table without disturbing digesta. The jejunum and the ileum were separated by the Meckel's diverticulum. Digesta from the ileum was quantitatively collected by gentle stripping. Digesta samples from the same treatment in the same block of two experimental rooms were pooled before being freeze-dried for DM, starch, nitrogen, and $\mathrm{Ti}$ analysis to calculate digestibility of DM, starch and CP. Apparent digestibility (AD) of DM, starch, CP was calculated by equation 1 :

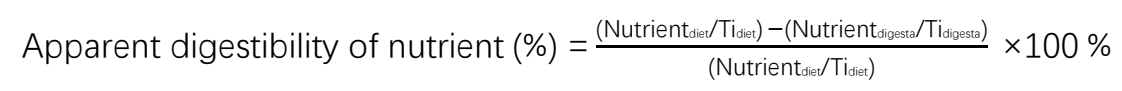

where Nutrient $t_{\text {diet }}$ and Nutrient $t_{\text {digesta }}(\%)$ are the nutrient (DM, starch or CP) content in the experimental diets (as-fed basis) and in the freeze-dried digesta samples, respectively, 
and $\mathrm{Ti}_{\text {diet }}$ and $\mathrm{Ti}_{\text {digesta }}(\%)$ are the $\mathrm{Ti}$ content in the sample experimental diets the digesta samples, respectively.

The $A M E_{n}$ value per $g$ of each of the experimental diets (as-fed basis) were calculated according to the method described by Hill and Anderson, (1958) using a value of $34.39 \mathrm{~kJ}$ per $\mathrm{g}$ of retained nitrogen to correct to zero nitrogen-retention.

\section{Exp 2. Growth performance trial}

\section{Design, animals, housing and feeding}

A total of 800 one-day-old male broilers (Ross 308, Aviagen Group, Newbridge, UK) housed in 40 floor pens with 20 broilers in each pen were used. Wood shavings were used as bedding material throughout the experimental period and the ambient temperature was kept at $33^{\circ} \mathrm{C}$ at experimental day 1 and gradually reduced to $21^{\circ} \mathrm{C}$. The relative humidity was at a minimal level of $60 \%$ during the first three days and between 40 and 70 \% from day 3 onwards. During the first two days, lights were continuously on (i.e. 24L : OD) while from day 3 onwards, lighting schedule followed a four-cycle $2 \mathrm{~L}: 4 \mathrm{D}$ regime. The experiment consisted of three stages: a starter (i.e. day 1 to 7 ), a grower (i.e. day 8 to 24) and a finisher (i.e. day 25 to 35) phase. During the starter phase, broilers were fed a commercial diet while the grower diets were fed from day 8 to 24 and the finisher diets from day 25 to 35. The experimental diets were provided in mash form and throughout the experiment, broilers had unrestricted access to feed and water.

\section{Data collection and calculation}

Total feed intake and body weight per pen were recorded at the end of each phase (i.e. day 7, 24 and 35). For each phase, feed conversion ratio (FCR) was calculated by dividing total feed intake by total body weight gain including dead birds. Average daily feed intake (ADFI) was calculated as the mean body weight gain (ADG) of live birds multiplied with the respective value for FCR. Energy conversion ratio (ECR) was calculated by dividing dietary ME intake, calculated using the results from the digestibility trial, by total body weight gain including dead birds. Average daily feed intake and ADG were expressed per bird and FCR and ECR per pen. At day 35, four broilers were randomly selected from each pen and slaughtered. Two out of these four broilers were used to determine carcass yield and breast meat yield (as \% of live weight). The other two were used to determine abdominal fat pad (as \% of live weight). 


\section{Chemical analysis}

All chemical analyses were performed according to standard laboratory methods. Dry matter was determined gravimetrically after drying at $103{ }^{\circ} \mathrm{C}$ for $4 \mathrm{~h}$ (ISO 6496; ISO, 1999). Gross energy was determined using bomb calorimetry (IKA-C700, Janke \& Kunkel, Heitersheim, Germany) (ISO 9831; ISO, 1998). Starch content was determined after enzymatically hydrolysis (method ISO 15914; ISO, 2004). Nitrogen was determined using Dumas method (method ISO 16634-1; ISO, 2008) using a Flash EA 1112 NC Analyzer (Thermo Fisher Scientific, Waltham, MA, USA). Titanium was determined according to (Myers et al., 2004). Uric acid was analysed calorimetrically using a commercial test kit (Human $\mathrm{GmbH}$, Wiesbaden, Germany).

\section{Statistical analysis}

All data were analysed by analysis of variance using the GLM procedure of SAS (version 9.3, SAS Institute Inc., Cary, NC) with starch source, protein source and their interaction as fixed effects and block as a random effect. Residuals of all dependent variables were tested for normality and non-normal distributed data were log transformed. Probability levels of less than $5 \%$ were considered to be statistically significant, and levels between 5 to $10 \%$ were considered a trend.

\section{RESULTS}

Apparent digestibility of experimental diets

Apparent ileal digestibility (AID) of DM was affected by starch source $(P<0.001)$ (Table 5.3). For the AID starch $_{\text {and }}$ AID $_{\mathrm{cp}}$, there was an interaction between starch and protein source $(P=0.008$ and $P<0.001$, respectively). Broilers fed RS diets showed a higher $A_{I D M}$ and $A_{D} D_{\text {starch }}$ than broilers fed PS diets. Apparent total tract digestibility (ATTD) of DM was affected by starch source $(P<0.001)$, with RS diets showing a higher $A_{T T D}$ than PS diets. For ATTD $D_{\text {сP }}$, there was an interaction between starch and protein source $(P<0.001)$. Broilers fed the PS-SBM and RS-SPI diets had a higher ATTD $\mathrm{CP}(83.9$ and $85.1 \%$, respectively) than broilers fed the PS-SPI and RS-SBM diets (82.5 and $82.4 \%$, respectively). Diets with RS showed a higher $\mathrm{AME}_{\mathrm{n}}$ than diets with $\mathrm{PS}(P<0.001)$. 


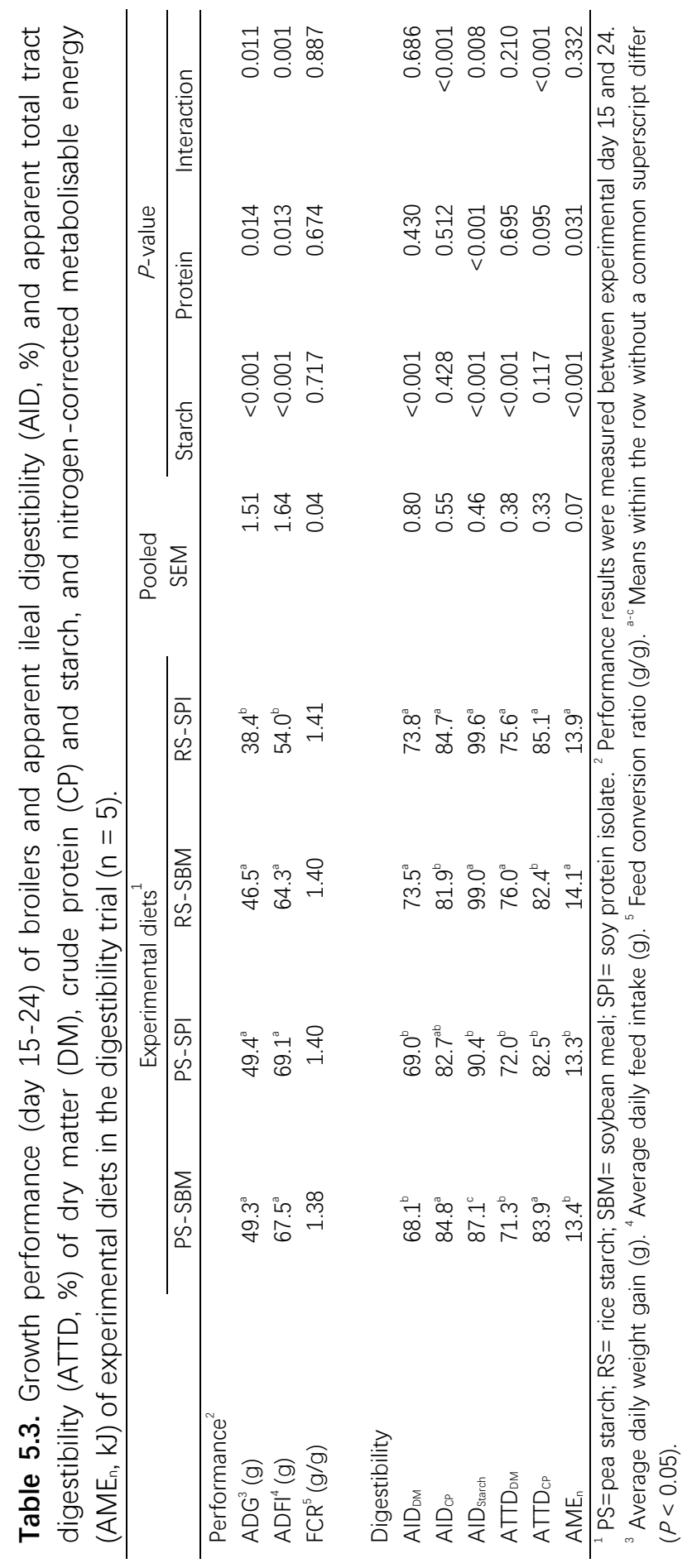




\section{Growth performance}

The initial body weight of broilers did not differ among treatments. During the grower stage (i.e. day 7-24), an interaction between starch and protein source was found for ADG, FCR and ERC. Broilers fed the RS-SPI diet showed the lowest ADG and ADFI (36.9 and $59.2 \mathrm{~g}$, respectively), and highest FCR and $\mathrm{ERC}(1.61 \mathrm{~g} / \mathrm{g}$ and $22.3 \mathrm{~kJ} / \mathrm{g}$, respectively) $(P<0.001)$ (Table 5.4). Broilers on the PS-SBM and PS-SPI diets showed a comparable growth performance. During the finisher stage (i.e. day 24-35), broilers on the PS-SBM diet showed the highest ADG and ADFI, and broilers on the RS-SPI diet the lowest, with broilers on the PS-SPI and RS-SBM diets being intermediate $(P<0.001)$. Broilers fed the RS-SPI diet showed a higher FCR and ECR $(1.74 \mathrm{~g} / \mathrm{g}$ and $24.1 \mathrm{~kJ} / \mathrm{g}$, respectively) than broilers fed the PS-SBM $(1.66 \mathrm{~g} / \mathrm{g}$ and $22.3 \mathrm{~kJ} / \mathrm{g}$, respectively; $P<0.001$ ). Over the entire experimental period (i.e. day 7-35), an interaction between starch source and protein source was found for ADG, FCR and ERC $(P<0.05)$. Broilers on the PS-SBM diet showed the best performance and broilers on the RS-SPI diet the worst over the entire experiment $(P<0.001)$. No interaction between starch and protein source was found for ADFI for both the grower and the finisher stages.

\section{Carcass characteristics}

Carcass characteristics were affected by protein source $(P<0.001)$ (Table 5.5). Birds fed the PS-SBM diet showed the highest slaughter weight and birds fed the RS-SPI diet the lowest. Broilers on diets with SPI showed higher carcass, breast meat and abdominal fat yields $(P<0.001)$ and breast to carcass ratio than broilers on diets with SBM $(P<0.001)$. 


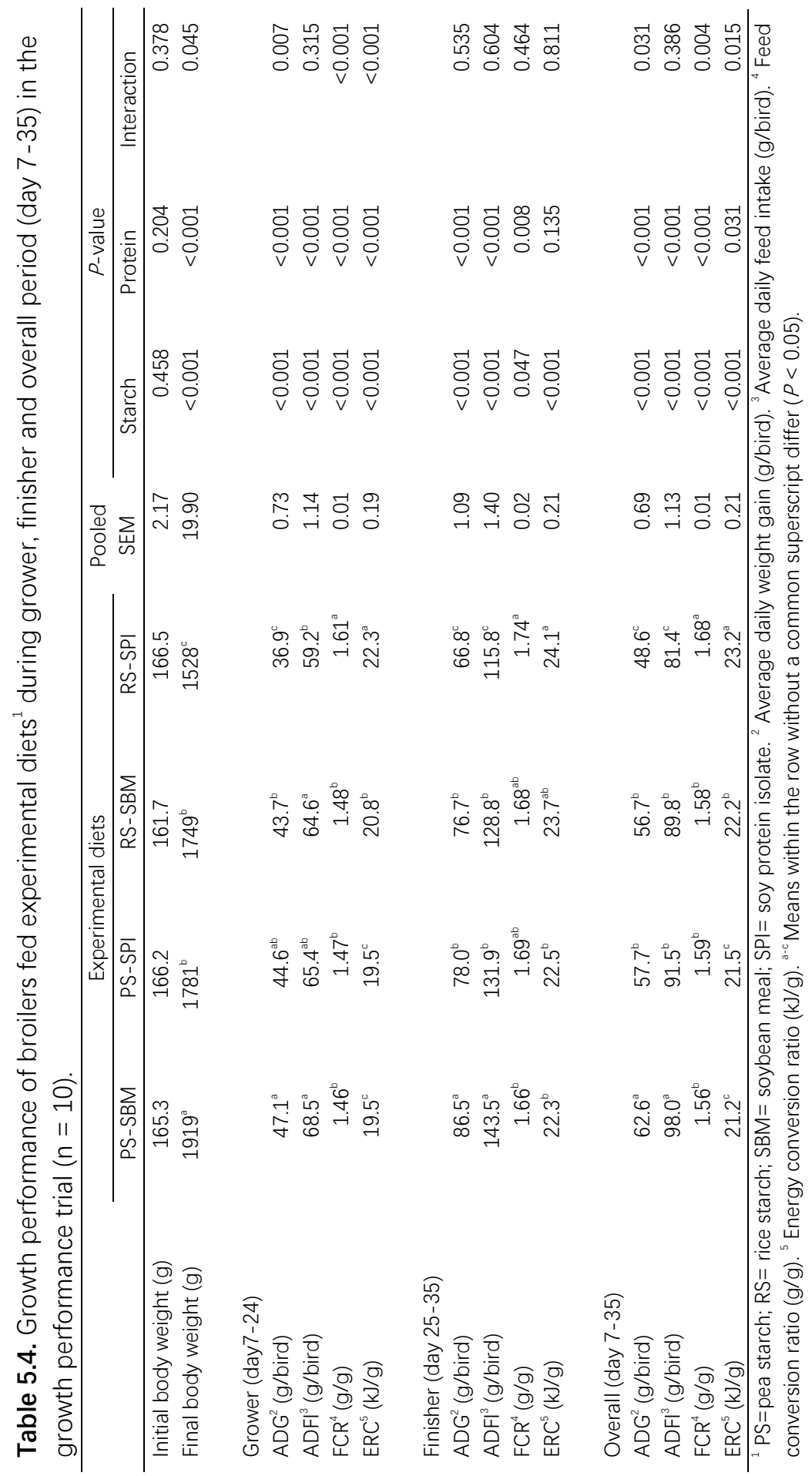




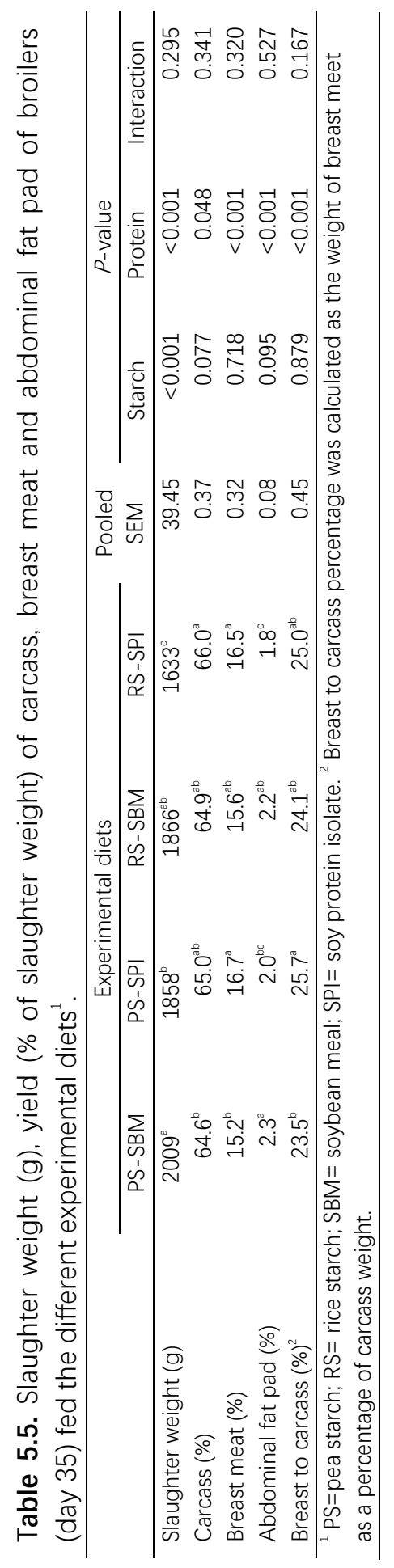




\section{DISCUSSION}

The objective of the present study was to determine if synchronising the digestion kinetics of dietary starch and protein affects the growth performance and carcass characteristics in broilers. Broilers were fed ad libitum over the experiment. Ad libitum feeding is commonly considered as continuous feeding, resulting in an evenly distributed intake of feed during the period of light and a steady passage of feed and digesta through the gastrointestinal tract where nutrient hydrolysis and absorption take place. Therefore, ad libitum supply of feed could possibly diminish the extent of asynchrony of the supply of glucose and AAs caused by the differences in digestion kinetics of dietary starch and protein compared to meal feeding. Ad libitum feeding, however, is not necessarily equal to continuous feeding, especially in broilers that are subjected to an intermittent lighting schedule (Weaver and Siegel, 1968; Savory, 1976). In the present study, the daily lighting schedule followed a four-cycle of $2 \mathrm{~L}: 4 \mathrm{D}$ regime. This intermittent lighting schedule might have induced a meal-like pattern of feed intake, potentially inducing an increase in asynchrony in the systemic supply of glucose and AAs.

The ADFI for all broilers in all treatments over the experimental period was $11-26 \%$ lower than the tabulated ADFI values for male Ross 308 broilers (Aviagen Group, 2014). Studies have shown that broilers fed mash diets showed a lower feed intake compared to broilers fed pelleted diets (Engberg et al., 2002; Amerah et al., 2007). Pelleting, however, is a hydrothermal process, which could induce gelatinisation of starch in diets (Abdollahi et al., 2013; Lewis et al., 2015), thereby increasing the digestion rate of dietary starch (Liu et al., 2013a). Thus, in order to ensure adequate differences in starch digestion kinetics, experimental diets were provided as mash. Unexpectedly, the ADFI was affected by the dietary starch and protein sources in both the grower and the finisher stages. Broilers fed diets with RS showed a lower ADFI than broilers fed PS starch. This might be related to a higher AID starch of the RS diets than the PS diets (99 vs. $89 \%$ ), leading to on average a $0.7 \mathrm{MJ} / \mathrm{kg}$ higher $\mathrm{AME}_{\mathrm{n}}$ value of the RS diets than the PS diets. Broilers were shown to be capable of adjusting their feed intake in response to dietary energy level to maintain their BWG, by increasing intake of low-energy diets (Leeson et al., 1996). Broilers fed the SBM diets showed a higher ADFI than broilers fed the SPI diets. The AID $\mathrm{CP}$ did not differ between the SBM and SPI diets. The difference in ADFI, therefore, could not be related to differences in the supply of digestible essential AAs. Soy protein isolate is a fast digestible protein source, which shows a fast release of AAs in the GIT of broilers (Chapter 4). A fast release of glucose and AAs from dietary 
starch and protein could slow down the gastric emptying via both endocrine and neurocrine signal pathways, leading to an increased satiety and a decreased feed intake in poultry (Richards and Proszkowiec-Weglarz, 2007). This feedback mechanism could also contribute to the explanation why broilers fed RS diets showed a lower ADFI.

It was hypothesised that broilers fed synchronised diets (i.e. PS-SBM and RS-SPI) would have a higher growth performance and breast meat yield compared to broilers fed asynchronized diets (i.e. PS-SPI and RS-SBM). Over the experimental period (i.e. day 7-35), birds fed the synchronised PS-SBM diet showed the highest ADG among all treatments, with the concomitant highest ADFI compared to the other treatments. The FCR did not differ in broilers fed the PS-SBM and RS-SBM diets. This is not in agreement with a study of Weurding et al. (2003) showing that feeding slowly digestible starch to broilers improved the feed conversion ratio by approximately $2 \%$. Birds fed the RS-SPI diet showed the lowest growth performance and ADFI among all treatments. The differences in ADFI among treatment in the present study hindered a proper evaluation of the effect of synchronising the digestion kinetics of dietary starch and protein on the growth performance of broilers.

Studies have shown that the simultaneous availability of AAs and glucose in organs and tissues increase protein retention in both growing pigs and broilers (van den Borne et al., 2007; Liu et al., 2013b). This could be explained by sparing AAs from being catabolised to produce energy in organs and tissues when sufficient glucose as energy substrate is available. As a consequence, the AAs can be used primarily for protein synthesis. Moreover, the postprandial increase of glucose in blood is commonly accompanied by an increased postprandial plasma insulin concentration. Insulin stimulates protein deposition and inhibits protein breakdown in muscle tissues (Rooyackers and Nair, 1997; Bigot et al., 2003). These suggest that broilers fed protein and energy synchronised diets could show a higher protein deposition and breast meat yield than broilers fed non-synchronised diets. The breast meat yield of the broilers in the present study, however, was not affected by the interaction between dietary starch and protein source, suggesting no effect of nutrient asynchrony, but was only affected by protein source. Broilers fed the SPI diets increased breast meat yield by $8 \%$ compared to broilers fed the SBM diets. This indicates, independent of the starch source, fast digestible protein sources might benefit muscle protein deposition in growing broilers. This is not in agreement with previous studies indicating that a more steady supply of AAs from slowly digestible protein sources, such as casein, could 
increase the overall protein retention in healthy young human subjects (Boirie et al., 1997; Dangin et al., 2001).

Fast and slowly digestible starch and protein sources were selected based on their differences in digestion rates. The digestion rate of the same source of RS and PS as used in the present study were determined in a study with pigs, in which RS showed a higher maximal starch digestion rate than PS $\left(0.65\right.$ vs. $\left.0.34 \% \cdot \mathrm{min}^{-1}\right)$ (van Kempen et al., 2010). With respect to protein sources, SPI had a 10 -fold higher maximum protein digestion rate than SBM in broilers (32.3 vs. $3.1 \% \cdot \mathrm{min}^{-1}$ ) (Chapter 4). However, the methods to determine the digestion rate of starch and protein sources were different in these two studies. Moreover, the digestion rate of the starch sources was determined in pigs, and not in broilers. The differences in digestive physiology (i.e. size of the GIT relative to body weight, digesta passage rate, and secretion and concentration of digestive enzymes) in pigs and poultry could affect the digestion rate. As a consequence, the dietary starch and protein sources as used in the present study were not synchronised based on their actual digestion rates determined in broilers. Synchronisation of the digestion of dietary starch and protein based on actual digestion rates might be a better approach. 


\section{CONCLUSION}

Broilers fed diets synchronised for the digestion rate of starch and protein (i.e. PS-SBM (slow-slow) and RS-SPI (fast-fast)) did not show a higher growth performance and breast meat yield compared to broilers fed the asynchronised diets (i.e. RS-SBM (fastslow) and PS-SPI (slow-fast)). The evaluation of the effect of synchronising the supply of dietary starch and protein, however, was hindered by feed intake being affected by dietary protein and starch source, in favour of using SBM compared to SPI and PS compared to RS.

\section{ACKOWLEDGEMENTS}

The authors gratefully acknowledge the financial support from the Wageningen UR "IPOP Customized Nutrition" programme financed by Wageningen UR (Wageningen, the Netherlands), the Dutch Ministry of Economic Affairs, Agriculture \& Innovation (the Hague, the Netherlands), WIAS graduate school (Wageningen, the Netherlands), Nutreco (Boxmeer, the Netherlands) and Darling Ingredients International (Irving, TX, USA). 


\section{REFERENCES}

Abdollahi, M. R., V. Ravindran, and B. Svihus. 2013. Pelleting of broiler diets: An overview with emphasis on pellet quality and nutritional value. Anim. Feed Sci. Technol. 179:1-23.

Adeleye, O. O., A. D. Ologhobo, and B. T. Oje-Adetule. 2016. Influence of carbohydrate source on digesta kinetics and postprandial glucose responses of broiler chicks. Livest. Sci. 188:37-42.

Amerah, A. M., V. Ravindran, R. G. Lentle, and D. G. Thomas. 2007. Influence of feed particle size and feed form on the performance, energy utilization, digestive tract development, and digesta parameters of broiler starters. Poult. Sci. 86:2615-2623.

Barbé, F., O. Ménard, Y. Le Gouar, C. Buffière, M.-H. Famelart, B. Laroche, S. Le Feunteun, D. Rémond, and D. Dupont. 2014. Acid and rennet gels exhibit strong differences in the kinetics of milk protein digestion and amino acid bioavailability. Food Chem. 143:1-8.

Bigot, K., M. Taouis, and S. Tesseraud. 2003. Refeeding and insulin regulate S6K1 activity in chicken skeletal muscles. J. Nutr. 133:369-373.

Boirie, Y., M. Dangin, P. Gachon, M. P. Vasson, J. L. Maubois, and B. Beaufrère. 1997. Slow and fast dietary proteins differently modulate postprandial protein accretion. Proc. Natl. Acad. Sci. 94:14930-14935.

Dangin, M., Y. Boirie, C. Garcia-Rodenas, P. Gachon, J. Fauquant, P. Callier, O. Ballèvre, and B. Beaufrère. 2001. The digestion rate of protein is an independent regulating factor of postprandial protein retention. Am. J. Physiol. Metab. 280:340-348.

Engberg, R. M., M. S. Hedemann, and B. B. Jensen. 2002. The influence of grinding and pelleting of feed on the microbial composition and activity in the digestive tract of broiler chickens. Br. Poult. Sci. 43:569579.

ISO. 1998. ISO 9831:1998. Animal feeding stuffs, animal products, and faeces or urine-Determination of gross calorific value-Bomb calorimeter method. International Organization for Standardization, Geneva, Switzerland.

ISO. 1999. ISO 6496:1999. Animal feeding stuffs-Determination of moisture and other volatile matter content. International Organization for Standardization, Geneva, Switzerland.

ISO. 2004. ISO 15914-1:2004. Animal feeding stuffs-Enzymatic determination of total starch content. International Organization for Standardization, Geneva, Switzerland.

ISO. 2008. ISO 16634-1:2008. Food products-Determination of the total $\mathrm{N}$ content by combustion according to the Dumas principle and calculation of the crude protein content-Part 1: Oilseeds and animal feeding stuffs. International Organization for Standardization, Geneva, Switzerland.

Leeson, S., L. Caston, and J. D. Summers. 1996. Broiler response to diet energy. Poult. Sci. 75:529-535.

Lewis, L. L., C. R. Stark, A. C. Fahrenholz, J. R. Bergstrom, and C. K. Jones. 2015. Evaluation of conditioning time and temperature on gelatinized starch and vitamin retention in a pelleted swine diet. J. Anim. Sci. 93:615-619.

Li, T. J., Q. Z. Dai, Y. L. Yin, J. Zhang, R. L. Huang, Z. Ruan, Z. Deng, and M. Xie. 2008. Dietary starch sources affect net portal appearance of amino acids and glucose in growing pigs. Animal 2:723-729.

Liu, S. Y., P. H. Selle, and A. J. Cowieson. 2013a. Influence of white-and red-sorghum varieties and hydrothermal component of steam-pelleting on digestibility coefficients of amino acids and kinetics of amino acids, nitrogen and starch digestion in diets for broiler chickens. Anim. Feed Sci. Technol. 186:53-63.

Liu, S. Y., P. H. Selle, and A. J. Cowieson. 2013b. The kinetics of starch and nitrogen digestion regulate growth performance and nutrient utilisation of broilers fed coarsely ground, sorghum-based diets. Anim. Prod. Sci. 53:1033-1040.

Myers, W. D., P. A. Ludden, V. Nayigihugu, and B. W. Hess. 2004. Technical note: a procedure for the preparation and quantitative analysis of samples for titanium dioxide. J. Anim. Sci. 82:179-183.

Richards, M. P., and M. Proszkowiec-Weglarz. 2007. Mechanisms regulating feed intake, energy expenditure, and body weight in poultry. Poult. Sci. 86:1478-1490.

Riesenfeld, G., D. Sklan, A. Bar, U. Eisner, and S. Hurwitz. 1980. Glucose absorption and starch digestion in the intestine of the chicken. J. Nutr. 110:117-121. 
Rooyackers, O. E., and K. S. Nair. 1997. Hormonal regulation of human muscle protein metabolism. Annu. Rev. Nutr. 17:457-485.

Savory, C. J. 1976. Effects of different lighting regimes on diurnal feeding patterns of the domestic fowl. Br. Poult. Sci. 17:341-350.

Sklan, D., and S. Hurwitz. 1980. Protein digestion and absorption in young chicks and turkeys. J. Nutr. 110:139-144.

van den Borne, J. J. G. C., J. W. Schrama, M. J. W. Heetkamp, M. W. A. Verstegen, and W. J. J. Gerrits. 2007. Synchronising the availability of amino acids and glucose increases protein retention in pigs. Animal 1:666-674.

van der Meulen, J., J. G. M. Bakker, B. Smits, and H. de Visser. 1997. Effect of source of starch on net portal flux of glucose, lactate, volatile fatty acids and amino acids in the pig. Br. J. Nutr. 78:533-544.

van Kempen, T. A. T. G., P. I. R. Regmi, J. J. Matte, and R. T. Zijlstra. 2010. In vitro starch digestion kinetics, corrected for estimated gastric emptying, predict portal glucose appearance in pigs. J. Nutr. 140:12271233.

Weaver, W. D., and P. B. Siegel. 1968. Photoperiodism as a factor in feeding rhythms of broiler chickens. Poult. Sci. 47:1148-1154.

Weurding, R. E., A. Veldman, W. A. G. Veen, P. J. van der Aar, and M. W. A. Verstegen. 2001. Starch digestion rate in the small intestine of broiler chickens differs among feedstuffs. J. Nutr. 131:2329-2335.

Weurding, R. E., H. Enting, and M. W. A. Verstegen. 2003. The effect of site of starch digestion on performance of broiler chickens. Anim. Feed Sci. Technol. 110:175-184. 
Chapter 6

General discussion 


\section{Aim and main findings of the thesis}

Increasing the protein efficiency is considered a main strategy for sustainable feeding of pigs and poultry. In practice, protein in pig and poultry diets originates from different ingredients, selected in diet formulation based on their nutritional value and costs of the ingredients. Currently, the nutritional value of protein sources in pig and poultry diets is based on the concentration of essential amino acids (AAs), and their digestibility up to the end of the ileum or the gastrointestinal tract (GIT) (NRC, 2012; CVB, 2016). The ileal and faecal digestibility of protein and AAs, however, only provide information on the quantity of protein and AAs apparently absorbed up to the end of the ileum or the GIT. They, however, do not provide information on the kinetics of protein digestion, which might affect the post-absorption metabolism of dietary AAs. The aim of this thesis, therefore, was to provide further insights into the digestion kinetics of dietary protein sources in the GIT of pigs and poultry, and the consequences of differences in digestion kinetics of dietary protein for the growth performance of broilers.

The main findings of this thesis are:

- Protein sources differ in digestion kinetics in growing pigs, with initial protein digestion rate ranging from $0.68 \% \cdot \mathrm{min}^{-1}$ for a rapeseed meal based diet to $3.04 \% \cdot \min ^{-1}$ for a dried porcine plasma protein based diet.

- Protein sources differ in digestion kinetics in broilers, with initial protein digestion rate ranging from $1.76 \% \cdot \mathrm{min}^{-1}$ for a rapeseed meal based diet to $30.7 \% \cdot \mathrm{min}^{-1}$ for a wheat gluten based diet.

- The initial protein digestion rate is on average 2.7-fold higher in broilers than in pigs with the exception of wheat gluten, which is far higher in broilers than in pigs.

- A fast digestion kinetics of dietary protein results in a more rapid and pronounced postprandial appearance of AAs and peptides in systemic blood of pigs.

- Protein hydrolysis in the GIT of pigs and broilers follows a "one-by-one" mechanism to AAs.

- Approximately $30 \%$ of peptides present in ileal digesta of pigs are < $10 \mathrm{kDa}$ in dependent of protein source, whereas almost no peptides $<10 \mathrm{kDa}$ are found in the ileal digesta of broilers.

- Synchronising the digestion kinetics of dietary starch and protein using rice starch (fast digestible), pea starch (slowly digestible), soy protein isolate (fast digestible), and soybean meal (slow digestible) does neither improve the growth performance 
nor the breast muscle yield of ad libitum fed broilers kept under a $2 \mathrm{~h} \mathrm{~L}$ and $4 \mathrm{~h} \mathrm{D}$ light regime.

\section{Selection of protein sources}

Soybean meal (SBM), wheat gluten (WG), rapeseed meal (RSM), dried porcine plasma protein (DPP), and black soldier fly larvae (BSF)) were the protein sources evaluated in the present thesis. Selection of these five protein sources was not only based on the differences in expected in vitro protein digestion kinetics (fast vs. slow) but also on their innate physicochemical characteristics. Soybean meal, WG and RSM are plant-derived sources, whereas DPP and BSF are protein sources of animal origin. Comparing the selected protein sources of plant origin, the protein fraction of SBM and RSM mainly consists of albumins and globulins while the protein fraction of WG mainly consists of prolamins and glutelins. Moreover, SBM, RSM and DPP are considered conventional sources, whereas BSF is a novel source. Although soy protein and rapeseed protein are also commercially available in isolated forms, SBM and RSM were selected because they are more widely used in commercial diets compared to soy and rapeseed protein isolates. Soy and rapeseed protein isolates are primarily used in weaner and starter diets for young animals. In addition, SBM and RSM contain a substantial fraction of non-protein constituents. The effect of the interaction between proteins and these constituents on protein digestion kinetics was of interest in the present thesis as well.

\section{What determines the digestion kinetics of dietary protein?}

The overall extent and the rate of dietary protein digestion are related to three aspects: 1) the passage of digesta along the GIT, 2) the hydrolysis of dietary protein, and 3) the absorption of AAs and di- and tri-peptides by the small intestinal mucosa. All three aspects can be affected by intrinsic characteristics of protein sources, the matrix of complete diets (i.e. the interactions with other ingredients) and the digestive physiology of animals (Figure 6.1). 


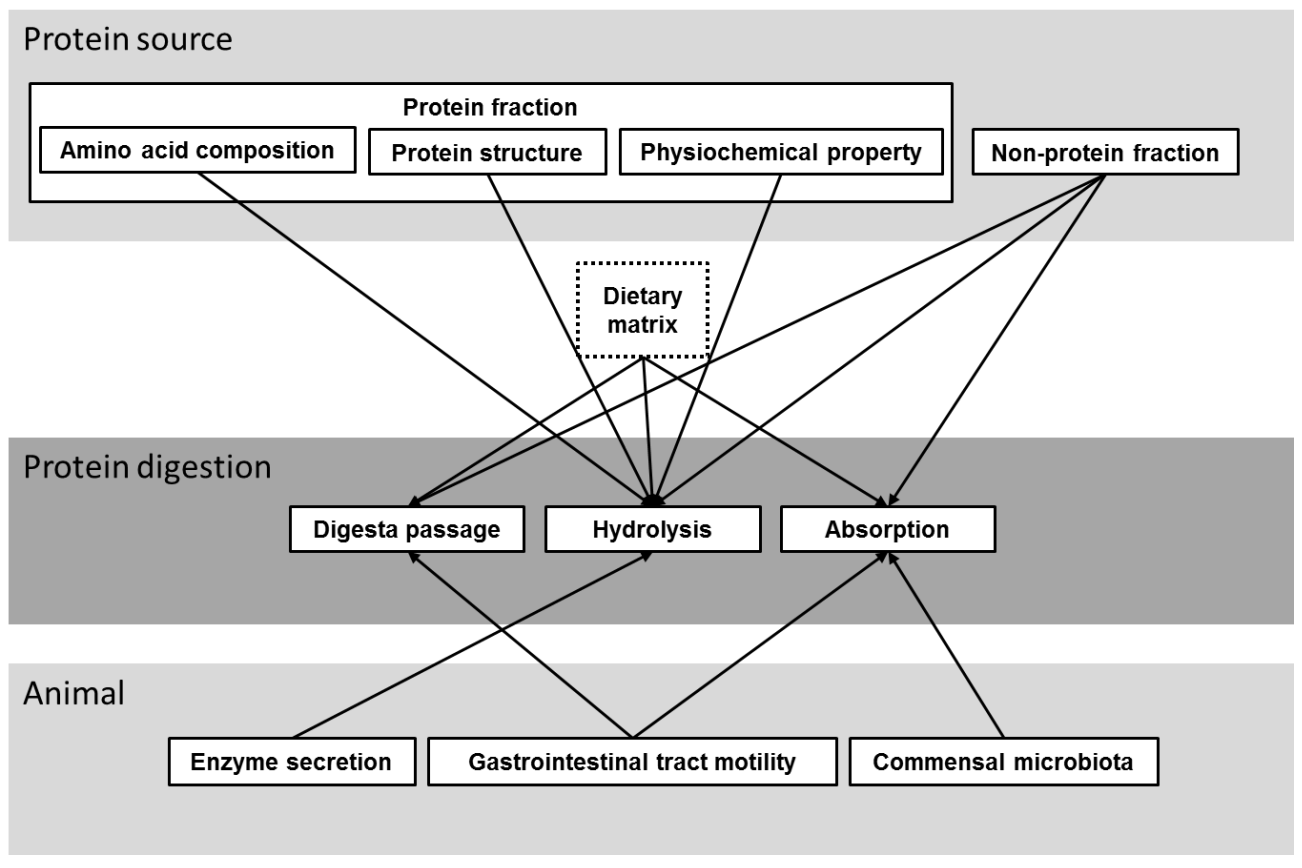

Figure 6.1. Overview of potential determinants of protein digestion kinetics in the gastrointestinal tract of pigs and poultry.

\section{Intrinsic characteristics of protein sources}

A protein source is composed of a protein fraction and can contain, depending on the protein source, a non-protein fraction including various levels of carbohydrates (i.e. sugars, starch and non-starch polysaccharides), fat and minerals. The protein content of the five sources evaluated in this thesis ranged from $36 \%$ for RSM to $88 \%$ for DPP. The protein fraction of most protein sources consists of different types proteins. The protein composition of SBM, RSM, WG and DPP is relatively well-defined (Table 6.1), whereas the protein composition of BSF remains largely unknown. The digestion of a protein source, therefore, is a combined result of the digestion of each protein present in the protein source. 
Table 6.1. Protein content and composition of different protein sources.

\begin{tabular}{lccc}
\hline Protein source & Protein content (\%) & Protein type & $\begin{array}{c}\text { Content } \\
\text { (\% of total protein) }\end{array}$ \\
\hline Soybean meal & $39-50$ & $\begin{array}{c}\text { Glycinin } \\
\text { B-Conglycinin }\end{array}$ & 31 \\
Rapeseed meal & $30-40$ & Cruciferin & $30-50$ \\
Wheat gluten & $73-84$ & Napin & 60 \\
& & Prolamin & $15-45$ \\
Porcine plasma & $67-78$ & Gluenin & 34 \\
& & Albumins & 34 \\
& & Globulins & 55 \\
& & Fibrinogen & 37 \\
\hline
\end{tabular}

Reference: Delisle et al. (1984); Sikorski (2006); Jamroz et al. (2011); Kriger (2014).

In both pigs and poultry, WG and DPP can be regarded as fast digestible while SBM, RSM and BSF as more slowly digestible protein sources (Chapter 3 and 4). Intrinsic characteristics of protein sources can be related to their 1) AA composition, 2) structural conformation, 3) physicochemical properties and 4) interactions with the non-protein fraction of proteins present in protein sources. Digestion of dietary protein starts in the stomach by the action of pepsin and hydrochloric acid but mainly occurs in the small intestine by the action of pancreatic proteases (i.e. trypsin and chymotrypsin and carboxypeptidase $A$ and $B$ ), followed by the hydrolysis by proteases and peptidases present at the intestinal brush border. Trypsin and chymotrypsin are endopeptidases, which cleaves the carboxyl end of basic AAs (arginine and lysine) and aromatic AAs (phenylalanine, tyrosine and tryptophan), respectively (Riviere and Tempst, 2001). These basic and aromatic AAs then can be released as free AAs by the action of carboxypeptidase A and B (Folk et al., 1960; Riviere and Tempst, 2001). Based on this, it could be assumed that basic and aromatic AAs would be released faster from dietary protein than the other AAs and therefore could be absorbed and enter the circulation faster. As a consequence, protein sources rich in basic and aromatic AAs might be digested faster. The portal appearance of these AAs, however, was not faster than that of the other AAs in pigs fed SBM and RSM diets (Jansman et al., 1994). In addition, DPP has a higher concentration of basic and aromatic AAs than the other protein sources. Dried porcine plasma protein, however, did not show a higher in vitro release rate of low molecular weight peptides $(<500 \mathrm{kDa}$ ) and free AAs than the other protein sources during the hydrolysis by the proteases in porcine pancreatin (Chapter 2). These results indicate that the effect of AA composition of protein sources on the kinetics of protein digestion is rather small. 
The conformation of proteins is mainly determined by the AA sequence of the polypeptide chains. Studies have shown that in vitro protein digestibility can be affected by the secondary structure of protein (Carbonaro et al., 2012; Rubio et al., 2014; Yang et al., 2016). A negative linear correlation coefficient was found between the content of $\beta$-conformation and the degree of hydrolysis of soy protein isolate by the action of pepsin (Yang et al., 2016). In addition, the presence of intramolecular $\beta$-sheet structures negatively affected in vitro protein digestibility of both animal- and plant-origin food proteins being hydrolysed by porcine trypsin, chymotrypsin and peptidases (Carbonaro et al., 2012). The latter authors suggested that the decrease in in vitro protein digestibility with an increased proportion of intramolecular $\beta$-sheet can be explained by the higher hydrophobicity of $\beta$-sheet structures. Prolamin and gliadin from WG have a lower content of $\beta$-sheets and higher ratio between $\alpha$-helix and $\beta$ sheet than glycinin and $\beta$-conglycinin from SBM and cruciferin and napin from RSM (Delisle et al., 1984; Sikorski, 2006). A higher ileal digestibility and faster protein digestion kinetics of WG than SBM and RSM, therefore, might be partly attributed to the secondary structure of proteins in wheat.

With respect to physicochemical properties, protein solubility plays a critical role in protein digestion. The in vitro hydrolysis rate of a water-soluble form of casein (i.e. $\mathrm{Na}^{+}$-caseinate) was 2-fold higher than that of water-insoluble casein at $\mathrm{pH} 8.0$ (Tonheim et al., 2007). Moreover, the soluble protein fraction of unprocessed RSM showed a 3-fold higher in vitro hydrolysis rate than the insoluble protein fraction (Salazar-Villanea et al., 2017). In Chapter 2, WG and DPP showed a higher nitrogen solubility under the simulated gastric $(\mathrm{pH} 3.5)$ and intestinal $(\mathrm{pH} \mathrm{6.8)} \mathrm{conditions} \mathrm{of} \mathrm{pigs,}$ which might explain why WG and DPP showed a faster digestion kinetics in the GIT of pigs.

Soybean meal and RSM consist of 20-30 \% of non-starch polysaccharides (NSP) (CVB, 2016), originating from plant cell wall structures. Non-starch polysaccharides can be further divided into insoluble NSP (i.e. mainly cellulose) and soluble NSP. An increase in the content of soluble NSP in pig and broiler diets results in a decreased absorption of AAs and other nutrients (King and Taverner, 1975; Choct and Annison, 1990). This is likely due to the fact that soluble NSP can increase the viscosity of digesta (Bach Knudsen, 2001), which could restrict the accessibility of proteases to dietary protein and absorption of AAs and di- and tri-peptides. Moreover, other anti-nutritional factors present in SBM (e.g. protease inhibitors, lectins, phytate) (Campbell and van der Poel, 
1998; Selle et al., 2012) and RSM (e.g. sinapine, phytic acid, tannins) (Mangan, 1988; Khajali and Slominski, 2012) could also hinder protein digestion in the GIT of pigs and poultry by binding to either proteases or dietary protein.

\section{Protein digestion in monogastric animals}

Animals regulate protein digestion mainly via protease secretion and GIT motility. The secretion of endogenous proteases is regulated by both endocrine and neurocrine signal pathways. The secretion of pepsinogen, the precursor of pepsin, and hydrochloric acid in the stomach is initiated by stimulation of vagal nerve during feeding (Saladin and Miller, 1998). The secretion of pepsinogen and hydrochloric acid is further stimulated by the action of gastrin, which is released by the presence of peptides present in the stomach and the duodenum (Skak-Nielsen et al., 1988). The secretion of pancreatic juice including various proteases and bicarbonate is also initiated by stimulation of the vagal nerve during gastric digestion. The secretion of pancreatic juice is further stimulated by the action of cholecystokinin and secretin. Cholecystokinin is released by the presence free fatty acids and AAs in the lumen of the gut (Saladin and Miller, 1998). The presence of basic and aromatic AAs, the end product of trypsin and chymotrypsin digestion is proven to cause the release of pancreatic juice (Niederau et al., 1986), most likely via the action of cholecystokinin. The release of secretin is related to the decreased $\mathrm{pH}$ in the duodenum due to the hydrochloric acid emptied from the stomach. The amount of endogenous proteases being secreted is affected by the presence of peptides and AAs in the diet. The loss of AAs of endogenous origin was higher in rats fed a diet with a mixture of peptides and AAs than rats fed a protein-free diet (Moughan and Rutherfurd, 1990). Moreover, the loss of endogenous AAs at ileal level is positively correlated to the concentration of peptides in the diet in growing pigs (Hodgkinson et al., 2000). These results indicate that the presence of dietary peptides and AAs lead to a higher secretion of endogenous proteases. In addition, the activity of endogenous proteases also increases with a higher protein intake in weaning pigs (Makkink et al., 1994). The form in which the dietary AAs are provided can also regulate the amount of endogenous proteases secreted. In growing pigs, dietary AAs provided in the form of free AAs resulted in a lower endogenous ileal AA loss than AAs provided in the form of peptides (Butts et al., 1993). This can be related to peptides requiring further hydrolysis in the GIT prior to absorption in the form of peptides and free AA, whereas free AAs are absorbed directly by the intestinal mucosa without further hydrolysis. 
Protein digestion requires a sufficient reaction time between proteolytic enzymes and dietary protein. A fast passage rate of digesta along the GIT, therefore, might hinder quantitative protein digestion. The passage rate is regulated by gut motility. The motility of the GIT is mainly regulated by the release of end products of digestion (i.e. glucose, AAs and fatty acids) via both endocrine and neurocrine signal pathways (SkakNielsen et al., 1988). The afferent vagal nerve acts as receptor which is activated by glucose, AAs and fatty acids along the small intestine. Once the vagal nerve detects the increased concentration of glucose, AAs and fatty acids, it slows down the GIT motility, leading to longer retention time of digesta in the GIT. With respect to endocrine pathways, gastric emptying is inhibited by the action of cholecystokinin, peptide YY and glucagon-like peptide (Moran and McHugh, 1982; Savage et al., 1987). As mentioned above, cholecystokinin is secreted in the duodenum, whereas peptide $Y Y$ and glucagon-like peptide are secreted in the ileum. The release of peptide $Y Y$ and glucagon-like peptide also reduce peristalsis of the small intestine, resulting in a longer retention time of digesta in the small intestine. In addition to GIT motility, the passage rate of digesta along the GIT also depends on the feeding pattern (i.e. feeding frequency and meal quantity) and the physicochemical properties (e.g. solubility, viscosity, water binding capacity) of digesta which are affected by dietary protein sources but also by characteristics of other ingredients in the diet. A large volume of a meal (Hunt and Stubbs, 1975), a high solubility of digesta (Low et al., 1978) and an increase in dietary fibre content (Wilfart et al., 2007) increase the passage rate of digesta along the GIT.

Dietary protein can also be fermented by the commensal microbiota in the GIT, which mainly occurs in the colon of pigs and the caeca of poultry. Dietary protein degraded in the hindgut by microbial fermentation does not significantly contribute to AA supply for animals and therefore does not directly affect the nutritional value of protein sources. The potentially toxic metabolites such as ammonia, amines, volatile phenols and indoles, produced during proteolytic fermentation can negatively affect gut health and animal performance (Williams et al., 2001). For example, ammonia produced by proteolytic fermentation can disturb the development of intestinal mucosa and reduce the villus height in chickens (Visek, 1984; Nousiainen, 1991), leading to a reduced nutrient absorption by the intestinal mucosa. Moreover, feeding poorly digestible protein sources and increasing the dietary protein concentration favoured the growth of pathogenic bacteria such as Clostridium perfringens, leading to an increased endogenous loss (Drew et al., 2004; Wilkie et al., 2005). 
Identifying potential determinants of protein digestion, related to both intrinsic characteristics of protein sources and the digestive physiology of animals, could help to develop strategies to increase protein and AA digestibility of feed ingredients used in pig and poultry diets.

\section{Possibilities to manipulate protein digestion}

Several factors determining the extent and the rate of protein digestion, related to both intrinsic characteristics of protein sources and the digestive physiology of animals, have been discussed above. It still remains unclear whether these factors can be manipulated to increase either the extent or the rate of protein digestion or both, especially of protein sources with a rather low digestibility. An overview of current strategies to increase digestibility of protein and AA of feed ingredients used in pig and poultry diets is presented in Figure 6.2.

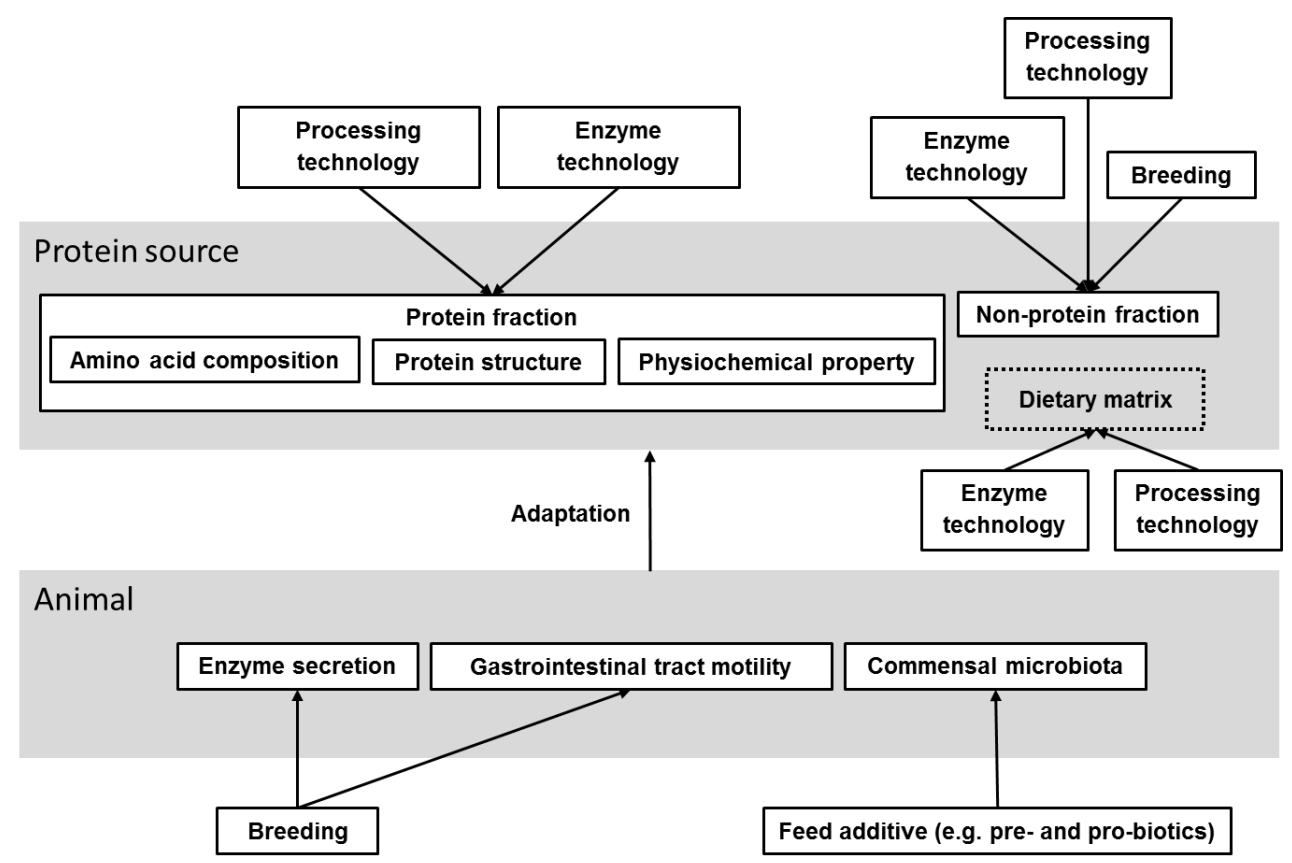

Figure 6.2. Overview of current strategies to increase protein and amino acid digestibility of feed ingredients used in pig and poultry diets.

With respect to the digestive physiology of monogastric animals, the secretion of digestive enzymes and the motility of the GIT are controlled by both endocrine and neurocrine systems, which involve several feedback mechanisms each. Possibilities to 
manipulate enzyme secretion and GIT motility by interfering with these feedback mechanisms seem rather small. By using genetic variation within and between breeds with respect to nutrient digestibility in breeding programmes, some key features of the digestive system (e.g. digestive enzyme secretion and digesta passage rate) could be changed. However, breeding might be a time-consuming and costly approach. As a consequence, the possibilities to manipulate protein digestion via changing components of the digestive system of animals seem rather small. However, animals adapt their digestive system according to the composition of the diet, suggesting it is possible to modify digestive capacity of animals via different dietary interventions. (Moughan and Rutherfurd, 1990; Butts et al., 1993; Makkink et al., 1994; Hodgkinson et al., 2000), As mentioned above, colonization of pathogenic bacteria in the GIT negatively affects nutrient absorption by the intestinal mucosa. Inclusion of pre- and pro-biotics in the diet, therefore, could be an approach to inhibit the growth of pathogenic bacteria and maintain health and digestive functions of the gut (Patterson and Burkholder, 2003; de Lange et al., 2010)

Hydrothermal processing is commonly applied to SBM and RSM in order to remove the organic solvents used for oil extraction. It could cause both chemical and physical changes of the proteins present and therefore negatively affect nutritional value of SBM and RSM. During hydrothermal processing, the Maillard reaction, the reaction between reducing sugars and AAs (mainly lysine and arginine), might occur. The Maillard reaction decrease AA concentration, their digestibility and post-absorptive utilisation (Messerschmidt et al., 2012; Almeida et al., 2014; Hulshof et al., 2017). Moreover, hydrothermal processing can reduce protein solubility in SBM and RSM (Hulshof et al., 2016), likely resulting in a decreased digestion rate. Indeed, the protein digestion rate of untoasted RSM was 1.3- and 1.6-fold higher than RSM toasted for 60 and 120 min, respectively (Salazar-Villanea, 2017). However, the shear force applied during hydrothermally processing, such as when using extrusion, can reduce particle size of feed ingredients, leading to an increased surface area which allows a better accessibility of digestive enzymes and therefore a higher nutrient digestibility (Wondra et al., 1995; Fastinger and Mahan, 2003). Moreover, hydrothermal processing can inactivate the anti-nutritional factors, such as trypsin inhibitors in legume seeds, leading to a higher digestibility of protein and AAs (van der Poel, 1990). Thus, hydrothermal processing could both negatively and positively affect the extent and the rate of protein digestion of protein sources. 
Supplementation of exogenous enzymes to pig and poultry diets is also applied to inactive antinutritional factors present in feed ingredients, which can increase the digestibility of AAs as well as other nutrient digestibility. For example, supplementation of dietary microbial phytase could increase ileal protein and AAs digestibility in pigs and poultry by releasing proteins bound to phytic acid (Ravindran et al., 1999; Traylor et al., 2001). In addition, exogenous proteases are used to inactive protease inhibitors present in legume seeds. However, the inclusion of exogenous proteases in a SBM-based broiler diet has inconclusive effects on ileal protein and AAs digestibility (Simbaya et al., 1996; Ghazi et al., 2002). This is likely due to the fact that the activity of protease inhibitors is largely reduced during the hydrothermal processing of SBM. The effect of proteases on the inactivation of protease inhibitors, therefore, is limited. Soluble NSP, originating from plant cell wall structures, can increase the viscosity of digesta (Bach Knudsen, 2001), which could restrict the accessibility of proteases to dietary protein and absorption of AAs and di- and tri-peptides. Supplementation of NSP-degrading enzymes, such as xylanases and $\beta$-glucanases, in pig and poultry diets have been shown to increase NSP degradation and reduce digesta viscosity, resulting in a higher ileal protein and AAs digestibility (Choct et al., 1999; Bedford, 2000; Nortey et al., 2008). Apart from processing technology and supplementation of dietary exogenous enzymes, plant breeding could also be an approach to reduce the content of antinutritional factors in feed ingredients. For example, low-phytic acid maize, barley and soybean meal have been successfully bred, with a 50-90\% reduction in phytic acid content compared to conventional ones (Raboy, 2002).

Current strategies to increase digestibility of protein and AA of feed ingredients mainly focus on the elimination of antinutritional factors present in feed ingredients. Hydrothermal processing could reduce protein solubility, resulting in an reduced protein digestion rate. Thus, the use of enzymes and plant breeding might be preferable methods to reduce the content of antinutritional factors. Also, prolonging the retention time of digesta in the GIT up to the large intestine, could increase the extent and rate of protein digestion. However, manipulating digesta retention time using dietary intervention, such as inclusion of guar gum and cellulose in the diet (Owusu-Asiedu et al., 2006), might also alter digesta viscosity and therefore affect protein hydrolysis and AA absorption. Future research, therefore, could focus on the alteration of digesta retention time without affecting digesta viscosity. 


\section{Digestion kinetics differs in pigs and poultry}

Broilers showed, on average, a 1.1-fold higher ileal protein digestibility and a 2.7-fold higher small intestinal protein digestion rate than growing pigs, with the exception of WG, for which the protein digestion rate was 22 -fold higher in broilers than in pigs. Moreover, a substantial proportion (30 \%) of peptides present in ileal digesta of pigs are $<10 \mathrm{kDa}$, whereas almost no peptides $<10 \mathrm{kDa}$ were present in the ileal digesta of broilers (Chapter 2 and 3). This is probably related to the differences in digestive physiology between pigs and broilers. Broilers have a greater size of the stomach and the small intestine relative to their body size than pigs (7.8 and $3.5 \%$ of body weight, respectively) (Barea et al., 2011; Mabelebele et al., 2014). Chickens have a crop, a part of the oesophagus, whereas pigs do not. Digestion of dietary protein can already take place in the crop by microbial fermentation (Rehman et al., 2007) although its contribution to the overall extent of protein digestion is unknown. The stomach of broilers is separated into two parts: the proventriculus and the gizzard. The proventriculus functions as a glandular stomach similar to the stomach of pigs and the gizzard is regarded as a muscular stomach. The physical force exerted by the gizzard can reduce particle size of feed ingredients, leading to a higher nutrient digestibility (Wondra et al., 1995; Fastinger and Mahan, 2003). This is likely due to a reduction in particle size which increases the surface area and would allow a better accessibility of digestive enzymes. Moreover, plant proteins are commonly encapsulated by a fibrous cell wall structure. The physical force exerted by the gizzard can open the cell wall structure, which also increases the accessibility of digestive enzymes to proteins. The gastric $\mathrm{pH}$ of pigs and broilers is comparable, with an average $\mathrm{pH}$ of 4.4 and 4.6, respectively (Merchant et al., 2011; Mabelebele et al., 2014). Pepsin of chickens, however, shows a broader $\mathrm{pH}$ range for optimal activity than porcine pepsin (CrévieuGabriel et al., 1999). The physical force exerted by the gizzard together with a broader $\mathrm{pH}$ range for optimal activity of broiler pepsin might result in a better gastric protein digestion in broilers than in pigs. A longer digesta retention time in the GIT might accommodate a sufficient reaction time between digestive enzymes and dietary protein. In this thesis, pigs showed a longer digesta retention time in the stomach and the small intestine than broilers (Chapter 2 and 3), which is in agreement with published results in the literature (Weurding et al., 2001b; DeSesso and Williams, 2008). Although the digesta retention time is shorter in broilers, the occurrence of antiperistaltic contractions (i.e. digesta reflux) in the GIT of poultry (Duke, 1982) provides the 
opportunity for an extended hydrolysis of nutrients in the gizzard and the small intestine (Basha and Duke, 1999).

Digestion is a result of both hydrolysis of dietary protein and absorption of released free AAs and di- and tri-peptides. The absorption rate of nutrients largely depends on the absorptive surface area of the intestinal mucosa. The absorptive surface not only relates to the luminal surface area of the small intestine but also to the characteristics (i.e. length, width, and density) of villi and microvilli. Chickens have a 1.2 fold larger total absorptive surface area per unit of body weight than pigs (43.3 vs. $36.7 \mathrm{~cm}^{2}$ per $\mathrm{g}$ body weight) (Chivers and Hladik, 1980; Mitjans et al., 1997). This could also contribute to explaining why broilers showed a higher extent and rate of protein digestion than pigs.

\section{Mechanism of protein digestion in the GIT of pigs and poultry}

At the start of this PhD project, protein digestion was considered as a cascade process, in which intact proteins were hydrolysed into intermediate molecular weight peptides in the proximal part of the GIT (stomach and duodenum). The resulting intermediate peptides would subsequently be further hydrolysed into low molecular weight peptides as they further transit to the distal part of the small intestine. With this perception, a gradual shift of high molecular weight proteins and peptides to low molecular weight peptides and free amino acids along the GIT was expected. In addition, it was assumed that proteins present in highly digestible protein sources would be more susceptible to hydrolysis by digestive enzymes, whereas proteins present in low digestible protein sources would be more resistant to proteolytic hydrolysis. As a consequence, the shift of molecular weight distribution of proteins and peptides would occur more rapidly in highly digestible protein sources, resulting in relatively higher low molecular weight peptides being present in the ileal digesta of pigs and broilers. In contrast to expectation, the molecular weight distribution of proteins and peptides remained rather similar throughout the segments of the GIT of pigs and broilers (Chapter 3 and 4). These results indicate that protein hydrolysis in GIT of pigs and broilers likely follow a "one-by-one" type of hydrolysis mechanism (Adler-Nissen, 1976) (Figure 6.3), meaning intact proteins are hydrolysed in one sequence into di- and tri-peptides and AAs prior to absorption. Results also indicate that, despite the differences in intrinsic characteristics of protein sources and digestive physiology of pigs and poultry, the 
mechanism of hydrolysis of proteins in protein sources and absorption of released AAs and di-and tri-peptides is rather similar in pigs and poultry independent of protein sources.

The rate limiting step in "one-by-one" type of hydrolysis mechanism is the denaturation of native proteins, in which native proteins lose their secondary and tertiary structures and are transformed into linear chains of AAs. Once the protein structure is opened and peptide bonds are exposed, proteases can rapidly hydrolyse proteins into end products. This suggests that protein denaturation might be a limiting factor in protein digestion in the GIT of pigs and poultry. Denaturation of dietary protein mainly occurs in the stomach by the action of hydrochloric acid. The degree of denaturation of proteins could be related to 1) the intrinsic characteristics of the protein sources, 2) the hydrothermal processing of feed ingredients and 3) the prevailing condition in the GIT of pigs and poultry. It can be speculated that proteins present in slowly and less digestible protein sources might show a lower degree of protein denaturation in the stomach. Indeed, food allergens, usually regarded as resistant proteins to enzymatic digestion, showed a higher stability towards the in vitro digestion by pepsin at pH 1.3 (Astwood et al., 1996). Moreover, increasing the pepsin concentration by 100 -fold did not change the stability of food allergens to the hydrolysis by pepsin, suggesting pepsin concentration was not the limiting factor for the hydrolysis of food allergens. Therefore, the resistance of food allergens against pepsin digestion could be attributed to their rigid conformational structures, leading to a low degree of protein denaturation under the acidic condition of the stomach. Thus, to further increase protein digestibility of poorly digestible protein sources, increasing protein denaturation in the GIT of pigs and poultry could be a worthwhile approach. 

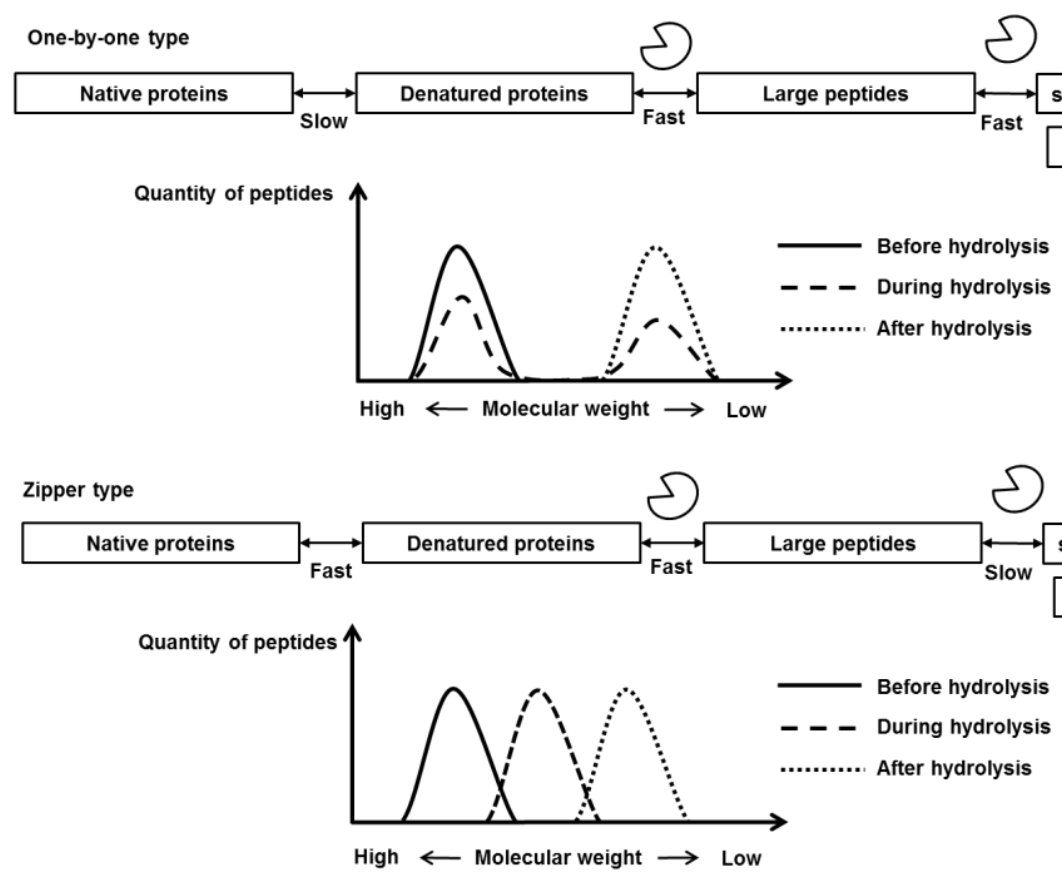

Figure 6.3. Schematic overview of the one-by-one type and zipper type mechanisms of protein hydrolysis in the digestive tract of pigs and poultry.

\section{Classification of dietary protein using in vitro approaches}

Dietary starch can be divided into different fractions: a rapidly digestible starch fraction (RDS), a slowly digestible starch fraction (SDS) and a resistant starch fraction (RS) using controlled in vitro enzymic hydrolysis (Englyst et al., 1992; Weurding et al., 2001a). The in vivo digestion kinetics of starch sources can be related to the proportional presence of these three fractions, of which fast digestible starch sources contain a higher RDS, whereas slow digestible starch sources contain a higher SDS (Weurding et al., 2001a). A similar classification might be applied to dietary protein in pig and poultry diets. In Chapter 2, the nitrogen present in feed ingredients after in vitro pepsin and pancreatin hydrolysis was separated into three fractions: a insoluble protein fraction (IPF), a soluble high molecular weight (> $500 \mathrm{Da}$ ) peptide fraction (HMW) and a soluble low molecular weight peptide fraction (LMW). The IPF can be compared with the resistant starch fraction, as it was assumed that nitrogen present in soluble form is absorbed in the GIT in vivo. Indeed, over the evaluated protein sources, the proportion of nitrogen present as soluble nitrogen was well-correlated to the in vivo apparent protein digestibility in 
both pigs and poultry (Figure 6.4A). The LMW and the HMW factions after in vitro protein hydrolysis were assumed to be the rapidly digestible protein fraction and the slowly digestible protein fraction, respectively. With this assumption, protein sources with a higher LMW, therefore, would be digested faster in vivo. However, such correlation between the proportion of LMW and in vivo digestion rate was observed in broilers but not in pigs (Figure 6.4B). The reason of the poor correlation found in pigs is unclear. However, it should be noted that only five protein sources were evaluated in the studies presented in this thesis. Follow-up studies using multiple batches of a large number of protein-containing feed ingredients should be carried out to validate if the current fractionation method of dietary protein using the in vitro approach as presented in this thesis (Chapter 2) can be used to predict in vivo protein digestion kinetics.
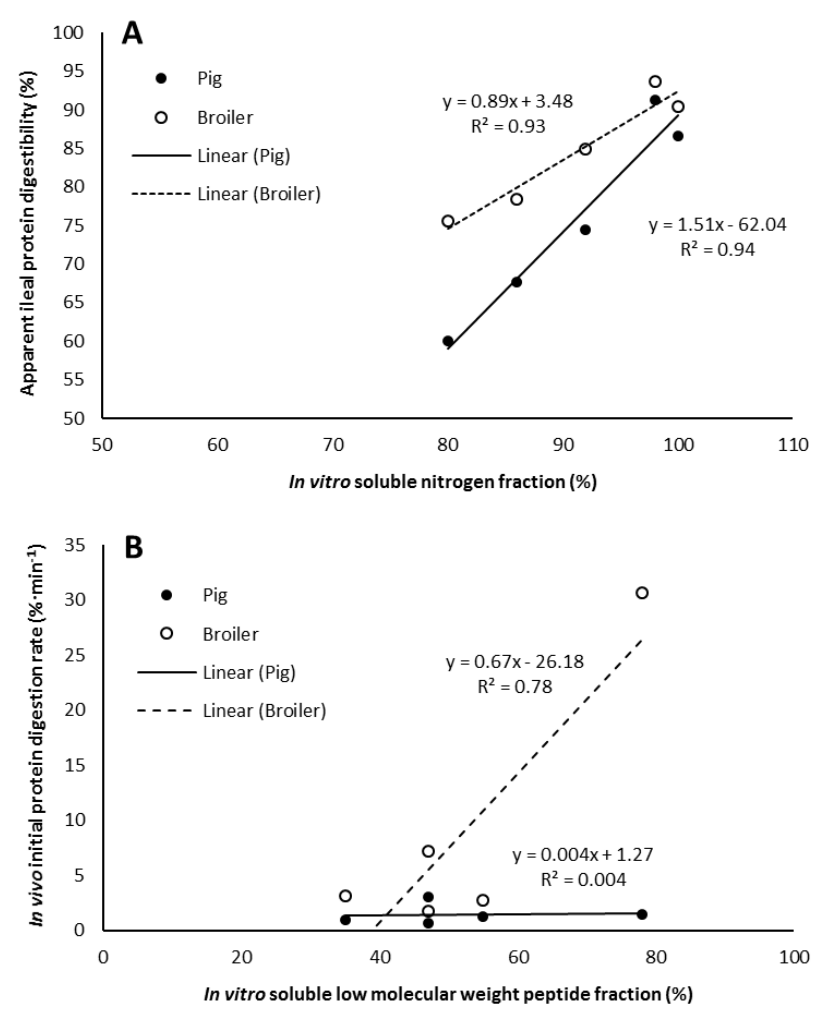

Figure 6.4. Relationship between soluble nitrogen fraction in protein sources after in vitro hydrolysis with pepsin and pancreatin (\%) and in vivo apparent protein digestibility (\%) of protein sources in pigs and poultry (A) and between soluble low molecular weight peptide fraction in protein sources after in vitro hydrolysis with pepsin and pancreatin (\%) and in vivo initial protein digestion rate $\left(\% \cdot \mathrm{min}^{-1}\right)$ of protein sources in pigs and poultry (B). 


\section{Synchronization of the supply of nutrients towards post-absorptive metabolism}

An efficient utilisation of dietary AAs for muscle protein synthesis is economically important in meat-producing animals particularly with forthcoming global protein scarcity. Amino acids are used by organs and tissues, either or not after transformation into other AAs, to synthesise proteins or as an energy source after deamination. The efficiency of protein utilisation depends on the balance between these two processes, in which a higher efficiency relates to a higher body protein deposition. The simultaneous availability of energy and AAs in tissues is prerequisite for protein synthesis (Geiger, 1950). Indeed, the simultaneous supply of energy and AAs, using the concept of nutrient synchronisation, increased nitrogen retention in growing pigs and broilers (van den Borne et al., 2007; Liu et al., 2013). In Chapter 5, synchronising the digestion kinetics of dietary starch and protein using both fast digestible sources (i.e. rice starch and soy protein isolate) or both slowly digestible source (i.e. pea starch and SBM) did not improve the performance nor the breast muscle yield of broilers. However, considerable differences in voluntary feed intake between experimental treatments, related to dietary starch and protein source, limited the capacity of the study to evaluate the concept of dietary energy and protein synchronization.

In addition to energy, a simultaneous availability of dietary AAs derived from either protein or from supplemented free AAs is also critical for maximizing body protein deposition. Protein sources are usually the most costly ingredients in pig and poultry diets. Commercially available free AAs (e.g. Iysine, methionine, threonine, tryptophan, valine, isoleucine, arginine, glycine) allow to lower the crude protein content of pig and poultry diets by 2-3\% while maintaining performance (Ospina-Rojas et al., 2014; Molist et al., 2016). Low crude protein diets are not only of economic interest but also reduce nitrogen emission (Liu et al., 2017). However, a reduction in dietary crude protein content by $6 \%$ reduced growth performance in pigs (He et al., 2016). This was related to the fast absorption of supplemented free AAs in the small intestine of pigs relative to the AAs derived from dietary protein, leading to an asynchrony in the availability of AAs in organs and tissues. Information on protein digestion kinetics as affected by protein sources presented in this thesis can be used to further develop concept of the synchronization of the supply of energy, protein-bound AAs and supplemented AAs to post-absorptive metabolism. 
The asynchrony in the supply of glucose and AAs might be more substantial in mealfed animals than in continuous-fed animals. Meal feeding might induce a more pronounced postprandial increase of plasma glucose and AAs. The fluctuation in plasma concentration of glucose and AAs is rather large over the day. In contrast, continuous feeding allows a steady flow of nutrients into the GIT, leading to smaller postprandial increase in plasma glucose and AA concentrations. Moreover, the plasma glucose and AAs concentrations remain more stable over the day (Figure 6.5). In practice, broilers are fed ad libitum. Ad libitum feeding, however, is not necessarily equal to continuous feeding, especially in broilers, for which the feeding pattern can be influenced by lighting schedule (Weaver and Siegel, 1968; Savory, 1976).
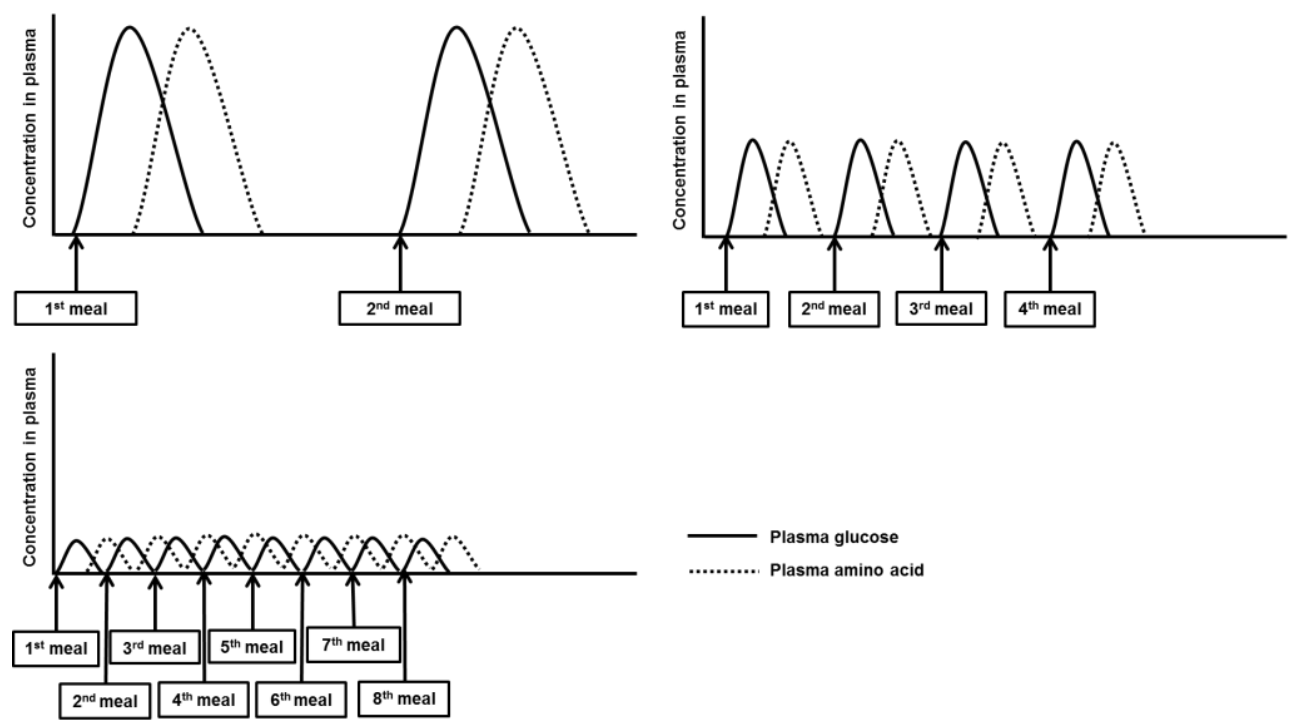

Figure 6.5. Schematic overview of postprandial increase in plasma concentrations of glucose and amino acids when feeding the same daily amount of amount feed in two, four or eight separate meals. 


\section{Overall conclusions and recommendations}

- The kinetics of protein digestion in the GIT differed substantially among protein sources in both pigs and poultry. Wheat gluten and DPP can be regarded as fast digestible protein sources while SBM, RSM and BSF as more slowly digestible protein sources. The differences in protein digestion kinetics can be attributed to intrinsic characteristics of protein sources and their consequent effects on synthesis, secretion and activity of digestive enzymes in the gut and to effects on digesta retention time. Protein digestion kinetics, as determined in this thesis, is a combined result of the digestion kinetics of all AAs. Future studies could also focus on the digestion kinetics of individual AAs.

- A higher rate and extent of protein digestion were observed in broilers compared to pigs. This might be related to differences in digestive physiology of pigs and broilers. However, despite the differences in intrinsic characteristics of protein sources and digestive physiology of pigs and poultry, the in vivo mechanism of hydrolysis of proteins in protein sources seems to be similar between these species.

- Separation of the nitrogen present in feed ingredients after in vitro pepsin and pancreatin hydrolyses into an insoluble protein fraction, a soluble high molecular weight (> $500 \mathrm{Da}$ ) peptide fraction and a soluble low molecular weight peptide fraction, as presented in this thesis, could potentially be used to predict in vivo protein digestion kinetics of pigs and poultry. However, follow-up studies using multiple batches of a large number of protein-containing feed ingredients should be carried out to validate this in vitro approach before it can be applied in practice.

- Synchronising the digestion kinetics of dietary starch and protein using either fast or slow digestible sources did not improve the growth performance and the breast muscle yield of ad libitum fed broilers kept under an intermittent light regime. Rather than categorising starch and protein sources into fast and slowly digestible sources, synchronising the digestion of dietary starch and protein based on their actual digestion rates might be a better approach to evaluate the concept of dietary energy and protein synchronization. 


\section{REFERENCES}

Adler-Nissen, J. 1976. Enzymic hydrolysis of proteins for increased solubility. J. Agric. Food Chem. 24:10901093.

Almeida, F. N., J. K. Htoo, J. Thomson, and H. H. Stein. 2014. Effects of heat treatment on the apparent and standardized ileal digestibility of amino acids in canola meal fed to growing pigs. Anim. Feed Sci. Technol. 187:44-52.

Astwood, J. D., J. N. Leach, and R. L. Fuchs. 1996. Stability of food allergens to digestion in vitro. Nat. Biotechnol. 14(10):1269-1273.

Barea, R., R. Nieto, F. Vitari, C. Domeneghini, and J. F. Aguilera. 2011. Effects of pig genotype (Iberian v. Landrace $\times$ Large White) on nutrient digestibility, relative organ weight and small intestine structure at two stages of growth. Animal 5:547-557.

Basha, M. E., and G. E. Duke. 1999. Effect of fasting on small intestinal antiperistalsis in the Nicholas turkey (Meleagris gallopavo). J. Exp. Zool. Part A: Ecol. Genet. Physiol. 283:469-477.

Bedford, M. R. 2000. Exogenous enzymes in monogastric nutrition-their current value and future benefits. Anim. Feed Sci. Technol. 86:1-13.

Butts, C. A., P. J. Moughan, W. C. Smith, and D. H. Carr. 1993. Endogenous lysine and other amino acid flows at the terminal ileum of the growing pig (20 kg bodyweight): the effect of protein-free, synthetic amino acid, peptide and protein alimentation. J. Sci. Food Agric.61:31-40.

Campbell, G. L., and A. F. B. van der Poel. 1998. Use of enzymes and process technology to inactivate antinutritional factors in legume seeds and rapeseed. Proc. 3rd Int. ANF Workshop Recent Advances of Research in Antinutritional Factors in Llegume Seeds and Rapeseed. A.J.M. Jansman et al. (eds.). EAAP Publication, 93; 377-386, Wageningen, the Netherlands.

Carbonaro, M., P. Maselli, and A. Nucara. 2012. Relationship between digestibility and secondary structure of raw and thermally treated legume proteins: a Fourier transform infrared (FT-IR) spectroscopic study. Amino Acids 43:911-921.

Chivers, D. J., and C. M. Hladik. 1980. Morphology of the gastrointestinal tract in primates: comparisons with other mammals in relation to diet. J. Morphol. 166:337-386.

Choct, M., and G. Annison. 1990. Anti-nutritive activity of wheat pentosans in broiler diets. Br. Poult. Sci. 32:811-821.

Choct, M., R. J. Hughes, and M. R. Bedford. 1999. Effects of a xylanase on individual bird variation, starch digestion throughout the intestine, and ileal and caecal volatile fatty acid production in chickens fed wheat. Br. Poult. Sci. 40:419-422.

Crévieu-Gabriel, I., J. Gomez, J.-P. Caffin, and B. Carré. 1999. Comparison of pig and chicken pepsins for protein hydrolysis. Reprod. Nutr. Dev. 39:443-454.

CVB. 2016. Chemical compositions and nutritional values of feed ingredients. Centraal Veevoeder Bureau, Wageningen, the Netherlands.

de Lange, C. F. M., J. Pluske, J. Gong, and C. M. Nyachoti. 2010. Strategic use of feed ingredients and feed additives to stimulate gut health and development in young pigs. Livest. Sci. 134(1):124-134.

Delisle, J., J. Amiot, G. Goulet, C. Simard, G. J. Brisson, and J. D. Jones. 1984. Nutritive value of protein fractions extracted from soybean, rapeseed and wheat flours in the rat. Foods Hum. Nutr. 34:243-251.

DeSesso, J. M., and A. L. Williams. 2008. Contrasting the gastrointestinal tracts of mammals: factors that influence absorption. Annu. Rep. Med. Chem. 43:353-371.

Drew, M. D., N. A. Syed, B. G. Goldade, B. Laarveld, and A. G. van Kessel. 2004. Effects of dietary protein source and level on intestinal populations of Clostridium perfringens in broiler chickens. Poult. Sci. 83:414-420.

Duke, G. E. 1982. Gastrointestinal motility and its regulation. Poult. Sci. 61:1245-1256.

Englyst, H. N., S. M. Kingman, and J. H. Cummings. 1992. Classification and measurement of nutritionally important starch fractions. Eur. J. Clin. Nutr. 46:S33-50.

Fastinger, N. D., and D. C. Mahan. 2003. Effect of soybean meal particle size on amino acid andenergy digestibility in grower-finisher swine. J. Anim. Sci. 81:697-704. 
Folk, J. E., K. A. Piez, W. R. Carroll, and J. A. Gladner. 1960. Carboxypeptidase B IV. Purification and characterization of the porcine enzyme. J. Biol. Chem. 235:2272-2277.

Geiger, E. 1950. The role of the time factor in protein synthesis. Science 111:594-599.

Ghazi, S., J. Rooke, H. Galbraith, and M. Bedford. 2002. The potential for the improvement of the nutritive value of soya-bean meal by different proteases in broiler chicks and broiler cockerels. Br. Poult. Sci. 43:70-77.

He, L., L. Wu, Z. Xu, T. Li, K. Yao, Z. Cui, Y. Yin, and G. Wu. 2016. Low-protein diets affect ileal amino acid digestibility and gene expression of digestive enzymes in growing and finishing pigs. Amino Acids 48:21-30.

Hodgkinson, S. M., P. J. Moughan, G. W. Reynolds, and K. A. C. James. 2000. The effect of dietary peptide concentration on endogenous ileal amino acid loss in the growing pig. Br. J. Nutr. 83:421-430.

Hulshof, T. G., A. F. B. van der Poel, W. H. Hendriks, and P. Bikker. 2016. Processing of soybean meal and 00rapeseed meal reduces protein digestibility and pig growth performance but does not affect nitrogen solubilization along the small intestine. J. Anim. Sci. 94:2403-2414.

Hulshof, T. G., A. F. B. van der Poel, W. H. Hendriks, and P. Bikker. 2017. Amino acid utilization and body composition of growing pigs fed processed soybean meal or rapeseed meal with or without amino acid supplementation. Animal 11:1125-1135.

Hunt, J. N., and D. F. Stubbs. 1975. The volume and energy content of meals as determinants of gastric emptying. J. Physiol. 245:209-225.

Jansman, A. J. M., H. Enting, M. W. A. Verstegen, and J. Huisman. 1994. Effect of condensed tannins in hulls of faba beans (Vicia faba L.) on the activities of trypsin (EC 2.4. 21.4) and chymotrypsin (EC 2.4. 21.1) in digesta collected from the small intestine of pigs. Br. J. Nutr. 71:627-641.

Khajali, F., and B. A. Slominski. 2012. Factors that affect the nutritive value of canola meal for poultry. Poult. Sci. 91:2564-2575.

King, R. H., and M. R. Taverner. 1975. Prediction of the digestible energy in pig diets from analyses of fibre contents. Anim. Sci. 21:275-284.

Knudsen, K. E. B. 2001. The nutritional significance of dietary fibre analysis. Anim. Feed Sci. Tech. 90:3-20.

Liu, S., J. Q. Ni, J. S. Radcliffe, and C. E. Vonderohe. 2017. Mitigation of ammonia emissions from pig production using reduced dietary crude protein with amino acid supplementation. Bioresour. Technol. 233:200-208.

Liu, S. Y., P. H. Selle, and A. J. Cowieson. 2013. The kinetics of starch and nitrogen digestion regulate growth performance and nutrient utilisation of broilers fed coarsely ground, sorghum-based diets. Anim. Prod. Sci. 53:1033-1040.

Low, A. G., I. Partridge, and I. Sambrook. 1978. Studies on digestion and absorption in the intestines of growing pigs. Br. J. Nutr. 39:515-526.

Mabelebele, M., O. J. Alabi, J. W. Ngambi, D. Norris, and M. M. Ginindza. 2014. Comparison of gastrointestinal tracts and $\mathrm{pH}$ values of digestive organs of Ross 308 broiler and indigenous Venda chickens fed the same diet. Asian J. Anim. Vet. Adv. 9:71-76.

Makkink, C. A., G. P. Negulescu, Q. Guixin, and M. W. A. Verstegen. 1994. Effect of dietary protein source on feed intake, growth, pancreatic enzyme activities and jejunal morphology in newly-weaned piglets. Br. J. Nutr. 72:353-368.

Mangan, J. L. 1988. Nutritional effects of tannins in animal feeds. Nutr. Res. Rev. 1:209-231.

Merchant, H. A., E. L. McConnell, F. Liu, C. Ramaswamy, R. P. Kulkarni, A. W. Basit, and S. Murdan. 2011. Assessment of gastrointestinal $\mathrm{pH}$, fluid and lymphoid tissue in the guinea pig, rabbit and pig, and implications for their use in drug development. Eur. J. Pharm. Sci. 42:3-10.

Messerschmidt, U., M. Eklund, V. T. S. Rist, P. Rosenfelder, H. K. Spindler, J. K. Htoo, and R. Mosenthin. 2012. Effect of particle size and heat treatment of soybean meal on standardized ileal digestibility of amino acids in growing pigs. J. Anim. Sci. 90:119-121.

Mitjans, M., G. Barniol, and R. Ferrer. 1997. Mucosal surface area in chicken small intestine during development. Cell Tissue Res. 290:71-78. 
Molist, F., J. Pijlman, P. J. van der Aar, M. Rovers, J. Ensink, and E. Corrent. 2016. Effect of low crude protein diets on growth performance and carcass characteristics of grower-finisher pigs. J. Anim. Sci. 94:226229.

Moran, T. H., and P. R. McHugh. 1982. Cholecystokinin suppresses food intake by inhibiting gastric emptying. Am. J. Physiol. Regul., Integr. Comp. Physiol. 242:491-497.

Moughan, P. J., and S. M. Rutherfurd. 1990. Endogenous flow of total lysine and other amino acids at the distal ileurn of the protein-or peptide-fed rat: The chemical labelling of gelatin protein by transformation of lysine to homoarginine. J. Sci. Food Agric. 52:179-192.

Niederau, C., J. H. Grendell, and S. S. Rothman. 1986. Digestive end products release pancreatic enzymes from particulate cellular pools, particularly zymogen granules. Biochim. Biophys. Acta-General Subj. 881:281-291.

Nortey, T. N., J. F. Patience, J. S. Sands, N. L. Trottier, and R. T. Zijlstra. 2008. Effects of xylanase supplementation on the apparent digestibility and digestible content of energy, amino acids, phosphorus, and calcium in wheat and wheat by-products from dry milling fed to grower pigs. J. Anim. Sci. 86:3450-3464.

Nousiainen, J. 1991. Comparative observations on selected probiotics and olaquindox as feed additives for piglets around weaning. J. Anim. Physiol. Anim. Nutr. 66:224-230.

NRC. 2012. Nutrient requirements of swine. Eleventh revised edition. National Academic Press, Washington, D.C., USA.

Ospina-Rojas, I. C., A. E. Murakami, C. R. A. Duarte, C. Eyng, C. A. L. Oliveira, and V. Janeiro. 2014. Valine, isoleucine, arginine and glycine supplementation of low-protein diets for broiler chickens during the starter and grower phases. Br. Poult. Sci. 55:766-773.

Owusu-Asiedu, A. J. F. J., J. F. Patience, B. Laarveld, A. G. van Kessel, P. H. Simmins, and R. T. Zijlstra. 2006. Effects of guar gum and cellulose on digesta passage rate, ileal microbial populations, energy and protein digestibility, and performance of grower pigs Br. Poult. Sci. 84:843-852.

Patterson, J. A., and K. M. Burkholder. 2003. Application of prebiotics and probiotics in poultry production. Poult. Sci. 82:627-631.

Raboy, V. 2002. Progress in breeding low phytate crops. J. Nutr. 132:503S-505S.

Ravindran, V., S. Cabahug, G. Ravindran, and W. L. Bryden. 1999. Influence of microbial phytase on apparent ileal amino acid digestibility of feedstuffs for broilers. Poult. Sci. 78:699-706.

Rehman, H. U., W. Vahjen, W. A. Awad, and J. Zentek. 2007. Indigenous bacteria and bacterial metabolic products in the gastrointestinal tract of broiler chickens. Arch. Anim. Nutr. 61:319-335.

Riviere, L. R., and P. Tempst. 2001. Enzymatic digestion of proteins in solution. Curr. Protoc. Protein Sci. 111.

Rubio, L. A., A. Pérez, R. Ruiz, M. Guzman, I. Aranda-Olmedo, and A. Clemente. 2014. Characterization of pea (Pisum sativum) seed protein fractions. J. Sci. Food Agric. 94:280-287.

Saladin, K. S., and L. Miller. 1998. Anatomy and physiology. WCB/McGraw-Hill, New York, USA.

Salazar-Villanea, S. 2017. Of proteins and processing. Mechanisms of protein damage upon rapeseed processing and their effects on nutritional value. PhD thesis. Wageningen University \& Reaseach, Wageningen, the Netherlands.

Salazar-Villanea, S., E. M. A. M. Bruininx, H. Gruppen, P. Carré, A. Quinsac, and A. F. B. van der Poel. 2017. Effects of toasting time on digestive hydrolysis of soluble and insoluble 00 -rapeseed meal proteins. J. Am. Oil Chem. Soc. 94:619-630.

Savage, A. P., T. E. Adrian, G. Carolan, V. K. Chatterjee, and S. R. Bloom. 1987. Effects of peptide YY (PYY) on mouth to caecum intestinal transit time and on the rate of gastric emptying in healthy volunteers. Gut 28:166-170.

Savory, C. J. 1976. Effects of different lighting regimes on diurnal feeding patterns of the domestic fowl. Br. Poult. Sci. 17:341-350.

Selle, P. H., A. J. Cowieson, N. P. Cowieson, and V. Ravindran. 2012. Protein-phytate interactions in pig and poultry nutrition: a reappraisal. Nutr. Res. Rev. 25:1-17.

Sikorski, Z. E. 2006. Chemical and functional properties of food components. CRC press. 
Simbaya, J., B. A. Slominski, W. Guenter, A. Morgan, and L. D. Campbell. 1996. The effects of protease and carbohydrase supplementation on the nutritive value of canola meal for poultry: in vitro and in vivo studies. Anim. Feed Sci. Technol. 61:219-234.

Skak-Nielsen, T., J. J. Holst, and O. V. Nielsen. 1988. Role of gastrin-releasing peptide in the neural control of pepsinogen secretion from the pig stomach. Gastroenterol. 95:1216-1220.

Tonheim, S. K., A. Nordgreen, I. Høgøy, K. Hamre, and I. Rønnestad. 2007. In vitro digestibility of watersoluble and water-insoluble protein fractions of some common fish larval feeds and feed ingredients. Aquaculture 262:426-435.

Traylor, S. L., G. L. Cromwell, M. D. Lindemann, and D. A. Knabe. 2001. Effects of level of supplemental phytase on ileal digestibility of amino acids, calcium, and phosphorus in dehulled soybean meal for growing pigs. J. Anim. Sci. 79:2634-2642.

van den Borne, J. J. G. C., J. W. Schrama, M. J. W. Heetkamp, M. W. A. Verstegen, and W. J. J. Gerrits. 2007. Synchronising the availability of amino acids and glucose increases protein retention in pigs. Animal 1:666-674.

van der Poel, A. F. B. 1990. Effect of processing on antinutritional factors and protein nutritional value of dry beans (Phaseolus vulgaris L.): a review. Anim. Feed Sci. Technol. 29:179-208.

Vioque, J., R. Sánchez-Vioque, A. Clemente, J. Pedroche, J. Bautista, and F. Millan. 1999. Production and characterization of an extensive rapeseed protein hydrolysate. J. Am. Oil Chem. Soc. 76:819-823.

Visek, W. J. 1984. Ammonia: its effects on biological systems, metabolic hormones, and reproduction. J. Dairy Sci. 67:481-498.

Weaver, W. D., and P. B. Siegel. 1968. Photoperiodism as a factor in feeding rhythms of broiler chickens. Poult. Sci. 47:1148-1154.

Weurding, R. E., A. Veldman, W. A. G. Veen, P. J. van der Aar, and M. W. A. Verstegen. 2001a. In vitro starch digestion correlates well with rate and extent of starch digestion in broiler chickens. J. Nutr.131:23362342.

Weurding, R. E., A. Veldman, W. A. G. Veen, P. J. van der Aar, and M. W. A. Verstegen. 2001b. Starch digestion rate in the small intestine of broiler chickens differs among feedstuffs. J. Nutr. 131:2329-2335.

Wilfart, A., L. Montagne, H. Simmins, J. Noblet, and J. van Milgen. 2007. Effect of fibre content in the diet on the mean retention time in different segments of the digestive tract in growing pigs. Livest. Sci. 109:2729.

Wilkie, D. C., A. G. van Kessel, L. J. White, B. Laarveld, and M. D. Drew. 2005. Dietary amino acids affect intestinal Clostridium perfringens populations in broiler chickens. Can. J. Anim. Sci. 85:185-193.

Williams, B. A., M. W. A. Verstegen, and S. Tamminga. 2001. Fermentation in the large intestine of singlestomached animals and its relationship to animal health. Nutr. Res. Rev. 14:207-228.

Wondra, K. J., J. D. Hancock, K. C. Behnke, R. H. Hines, and C. R. Stark. 1995. Effects of particle size and pelleting on growth performance, nutrient digestibility, and stomach morphology in finishing pigs. J. Anim. Sci. 73:757-763.

Yang, Y., Z. Wang, R. Wang, X. Sui, B. Qi, F. Han, Y. Li, and L. Jiang. 2016. Secondary structure and subunit composition of soy protein in vitro digested by pepsin and its relation with digestibility. Biomed Res. Int. 11 p, DOI: http://dx.doi.org/10.1155/2016/5498639. 
$148 \mid$ P a g 
List of abbreviations 


\begin{tabular}{|c|c|}
\hline$A A(s)$ & Amino acid(s) \\
\hline ADFI & Average daily feed intake \\
\hline ADG & Average daily gain \\
\hline AID & Apparent ileal digestibility \\
\hline Ala & Alanine \\
\hline $\mathrm{AME}_{\mathrm{n}}$ & Nitrogen-corrected apparent metabolisable energy \\
\hline Arg & Arginine \\
\hline Asx & Asparagine/Aspartic acid \\
\hline ATTD & Apparent total tract digestibility \\
\hline AUC & Area under the curve \\
\hline BSF & Black soldier fly larvae \\
\hline BW & Body weight \\
\hline $\mathrm{BW}^{0.75}$ & Metabolic body weight \\
\hline $\mathrm{CP}$ & Crude protein \\
\hline Cr-EDTA & Chromium ethylenediamine tetraacetic acid \\
\hline CVB & Centraal Veevoeder Bureau \\
\hline Cys & Cysteine \\
\hline $\mathrm{Da}$ & Dalton \\
\hline DDGS & Distillers dried grains with solubles \\
\hline DM & Dry matter \\
\hline DPP & Dried porcine plasma protein \\
\hline ERC & Energy conversion ratio \\
\hline FAO & Food and Agricultural Organization of the United Nations \\
\hline FCR & Feed conversion ratio \\
\hline Glx & Glutamine/ Glutamic acid \\
\hline GIT & Gastrointestinal tract \\
\hline GLM & General linear model \\
\hline Gly & Glycine \\
\hline His & Histidine \\
\hline HMW & High molecular weight peptides \\
\hline lle & Isoleucine \\
\hline INRA & Institut National de la Recherche Agronomique (France) \\
\hline IPF & Insoluble protein fraction \\
\hline ISO & International Organization for Standardization \\
\hline Leu & Leucine \\
\hline LMW & Low molecular weight peptides \\
\hline
\end{tabular}




$\begin{array}{ll}\text { Lys } & \text { Lysine } \\ \text { Met } & \text { Methionine } \\ \text { MW } & \text { Yellow meal worm larvae } \\ \text { N } & \text { Nitrogen } \\ \text { NA } & \text { Not available } \\ \text { NE } & \text { Net energy } \\ \text { NRC } & \text { National research council } \\ \text { NSP } & \text { Non-starch polysaccharides } \\ \text { Phe } & \text { Phenylalanine } \\ \text { Pro } & \text { Proline } \\ \text { PS } & \text { Pea starch } \\ \text { RS } & \text { Rice starch } \\ \text { RSM } & \text { Rapeseed meal } \\ \text { RT } & \text { Retention time } \\ \text { SBM } & \text { Soybean meal } \\ \text { SD } & \text { Standard deviation } \\ \text { SEC } & \text { Size exclusion chromatography } \\ \text { SEM } & \text { Standard error of the mean } \\ \text { Ser } & \text { Serine } \\ \text { SI } & \text { Small intestine } \\ \text { SID } & \text { Standardized ileal digestibility / Standardized ileal digestible } \\ \text { SPF } & \text { Soluble protein fraction } \\ \text { SPI } & \text { Soy protein isolate } \\ \text { Thr } & \text { Threonine } \\ \text { TiO } & \text { Titanium dioxide } \\ \text { Trp } & \text { Tryptophan } \\ \text { Tyr } & \text { Tyrosine } \\ \text { UN } & \text { United nations } \\ \text { Val } & \text { Valine } \\ \text { VFA(s) } & \text { Volatile fatty acid(s) } \\ \text { WG } & \text { Wheat gluten } \\ \text { WP } & \text { Whey protein } \\ & \\ & \\ \text { SE } & \end{array}$


$152 \mid \mathrm{P}$ a g e 


\section{Summary}


Increasing the protein efficiency is considered a main strategy for sustainable feeding of pigs and poultry. In practice, protein in pig and poultry diets originates from different ingredients, selected in diet formulation based on their nutritional value and cost. Currently, the nutritional value of protein sources in pig and poultry diets is based on the concentration of essential amino acids (AAs), and their digestibility up to the end of the ileum or the gastrointestinal tract (GIT) (NRC, 2012; CVB, 2016). The ileal and faecal digestibility of protein and AAs, however, only provide information on the quantity of protein and AAs apparently absorbed up to the end of the ileum or over the entire GIT, respectively. They, however, do not provide information on the kinetics of protein digestion, which might affect the post-absorption metabolism of dietary AAs. The aim of this thesis, therefore, was to provide further insights into digestion kinetics of dietary protein sources in the GIT of pigs and poultry, and the consequences of differences in digestion kinetics of dietary protein for the growth performance of broilers.

\section{Protein digestion kinetics in pigs and poultry}

In Chapter 2, in vitro protein digestion kinetics of various protein sources (soybean meal (SBM), wheat gluten (WG), rapeseed meal (RSM), whey powder (WP), dried porcine plasma protein (DPP), yellow meal worm larvae (MW), and black soldier fly larvae (BSF)) were determined using a two-step method. Protein sources were incubated with pepsin at $\mathrm{pH} 3.5$ for $0-90 \mathrm{~min}$ and subsequently with pancreatin at $\mathrm{pH} 6.8$ for $0-210 \mathrm{~min}$ at $39{ }^{\circ} \mathrm{C}$. Protein sources showed substantial differences in in vitro protein digestion kinetics as measured by the kinetics of $\mathrm{N}$ solubilisation and the release of low molecular weight peptides (<500 Da). The $\mathrm{N}$ solubilisation rate ranged from $0.025 \mathrm{~min}^{-1}$ for BSF to $0.685 \mathrm{~min}^{-1}$ for WP during the incubation with pepsin, and from $0.027 \mathrm{~min}^{-1}$ for RSM to $0.343 \mathrm{~min}^{-1}$ for WP during the incubation with pancreatin. The rate of release of low molecular weight peptides ranged from $0.027 \mathrm{~min}^{-1}$ for WG to $0.093 \mathrm{~min}^{-1}$ for WP during the incubation with pepsin, and from $0.029 \mathrm{~min}^{-1}$ for SBM to $0.385 \mathrm{~min}^{-1}$ for WP. Over all protein sources evaluated, no correlation was found between the rate of $\mathrm{N}$ solubilisation and the rate of release of low molecular weight peptides.

Based on the in vitro results, SBM, RSM, WG, DPP and BSF were selected for further investigations into in vivo protein digestion kinetics in both pigs (Chapter 3) and broiler chickens (Chapter 4). Forty pigs were randomly allocated to one of the five experimental diets containing the respective protein sources as the only source of protein. Four pigs per experimental diet were fitted with an ear-vein catheter and blood samples were 
collected before and after a morning meal. At dissection, digesta samples from the stomach and the small intestine, divided into four segments of equal length, were quantitatively collected. Apparent digestibility of crude protein (CP), and retention time (RT) of the solid fraction of digesta along the stomach and the SI were determined to calculate protein digestion kinetics. The initial protein digestion rate ranged from $0.68 \% \cdot \mathrm{min}^{-1}$ for the RSM based diet to $3.04 \% \cdot \mathrm{min}^{-1}$ for the DPP diet. A higher digestion kinetics of dietary protein resulted in a more rapid and pronounced postprandial appearance of AAs and peptides in systemic blood of pigs.

In the broiler trial, a total of 37826 -day-old male broilers with average body weight of $1430 \pm 48 \mathrm{~g}$ were randomly allocated to 42 pens. Pens were randomly allocated to one of the seven diets (i.e. a basal diet and six experimental diets with SBM, soy protein isolate (SPI), WG, RSM, DPP or BSF as the main protein source). At dissection, digesta samples from the crop, gizzard, duodenum, proximal jejunum, distal jejunum, and ileum were quantitatively collected. The CP digestion kinetics of the experimental diets were calculated by relating the apparent CP digestibility coefficient at each segment of the small intestine to the sum of digesta retention up to that segment. The initial protein digestion rate ranged from $1.76 \% \cdot \mathrm{min}^{-1}$ for the $\mathrm{RSM}$ based diet to $30.7 \% \cdot \mathrm{min}^{-1}$ for the WG based diet.

\section{Mechanism of protein hydrolysis in the GIT of pigs and poultry}

It was hypothesised that proteins present in highly digestible protein sources (i.e. WG and DPP) are more susceptible to hydrolysis by digestive enzymes than slow digestible protein sources (i.e. SBM, RSM and BSF) and that enzymatic hydrolysis of protein progress stepwise in the small intestinal intestine, resulting in hydrolysis products (peptides) becoming smaller in size towards the end of the small intestine. As a consequence, relatively more low and intermediate molecular weight peptides were expected to be present in ileal digesta of pigs and broilers fed highly digestible protein sources, compared to sources with a lower digestibility. The molecular weight distribution of soluble proteins and peptides in digesta from the different segments of the GIT of pigs and broilers was analysed using size exclusion chromatography (Chapter 3 and 4). The molecular weight distribution of proteins and peptides in ileal digesta of pigs and broilers fed highly digestible protein sources was comparable to those of pigs and broilers fed low digestible protein sources. In addition, the molecular weight distributions were rather similar throughout segments of the GIT. These results indicate 
that proteins from both highly and low digestible sources follow a "one-by-one" type of hydrolysis mechanism, meaning intact proteins are hydrolysed to low molecular weight peptides and free AAs and absorbed by the intestinal mucosa in one sequence. As a result, proteins and peptides with a wide range of molecular weights were not observed in digesta of different segments of the GIT. Approximately $30 \%$ of peptides present in ileal digesta of pigs are $<10 \mathrm{kDa}$ in dependent of protein source, whereas almost no peptides $<10 \mathrm{kDa}$ were found in the ileal digesta of broilers.

\section{Synchronisation the supply of dietary starch and protein}

The effects of synchronising the supply of dietary protein and starch using information on their kinetics of digestion on the growth performance and carcass characteristics in broilers was investigated (Chapter 5). Two starch and two protein sources were used: pea starch (PS) and SBM as slowly digestible sources while rice starch (RS) and SPI as fast digestible sources. Broilers fed diets synchronised for digestion rate of starch and protein (i.e. PS-SBM (slow-slow) and RS-SPI (fast-fast)) did not show a higher growth performance and breast meat yield compared to broilers fed the asynchronised diets (i.e. RS-SBM (fast-slow) and PS-SPI (slow-fast)). The evaluation of the effect of synchronising the supply of dietary starch and protein, however, was hindered by feed intake being affected by dietary protein and starch source. Feed intake of birds was higher when fed diets with SBM compared to SPI and when PS was fed instead of RS.

\section{Conclusions}

The results of the present thesis indicate that the kinetics of protein digestion in the GIT of pigs and poultry differs substantially among protein sources. Wheat gluten and DPP can be regarded as fast digestible protein sources while SBM, RSM and BSF are more slowly digestible protein sources in both pigs and broilers. Broilers showed on average a 2.7-fold higher small intestinal protein digestion rate than pigs, excluding and with the exception of WG, for which the protein digestion rate was very high in broilers compared to pigs. However, despite differences in intrinsic characteristics (e.g. AA composition, protein conformation, physicochemical properties) of protein sources and in digestive physiology of pigs and poultry, the mechanism of hydrolysis of dietary proteins in the gut seems rather similar. Synchronising the digestion kinetics of dietary starch and protein using both fast digestible sources or both slowly digestible sources did not improve the performance nor the breast muscle yield of ad libitum fed broilers kept under an intermittent light regime. 
Acknowledgment 
Finally, my PhD life is coming to an end. Accomplishing this $\mathrm{PhD}$ thesis is definitely not an easy job and I could never do it without help and supports from many people along this journey.

First of all, I would like to give my gratitude to Wouter. As my promotor, I really appreciate your inspiring input to the project, especially in the last stage of my $\mathrm{PhD}$. Regardless of your packed agenda, your door was always open for questions and discussions. Thank you for your guidance over the past years. Apart from that, you and Mirian organised dinners for us. You not only take care of nutrition for animals but also for your PhDs! Harry, although you only joined the project team in the beginning (which was taken over by Peter), I appreciate your critical feedback during our project meetings. Many thanks to my daily supervisors: Alfons and Peter. Alfons, you have been supportive and encouraging along this journey. You gave me great flexibility to this PhD project and made sure I did not deviate from the goals by giving needed guidance. You were always available for my questions and gave me instant feedback. Thank you for your very valuable comments on my work. I really look forward working with you again in the future. Peter, it is really nice to have you in my supervision team. You always had a keen eye on things that Alfons and I did not see as animal nutritionists. I really enjoyed our discussions. Thank you for your detailed comments on my manuscripts although sometimes it might take some courage to open files from you as I said to you before ;)

My special thanks to Betty and Yvonne, who were always there to help with anything. Without these two ladies, I might even not be able to stay in the Netherlands legally ;)

This thesis could never be completed without the help from the personnel of the Animal Research Facility in Lelystad (Gerrit Jan and Albert) and the staff of the Animal Nutrition Lab (Leon, Saskia, Michel, Jane-Martine, Xuan-Huong and Erika). Ruud and Piet, I really appreciate your efforts on my animal trials in Lelystad. Guido, Pierre, Sonja, Tetske, and Yvonne, thank you for your help with sample collection during my trials. Saskia, thank you for being flexible that I could prepare my samples for analyses with a short notice. Claire, thank you for your help and sharing your lab bench with me during my analyses in FCH. Many thanks to my MSc students (Chen-Yan, Fan, Mareen and Pei-Yun) for your help in my experiments. I hope you all learned something during your MSc thesis. For sure I learned a lot from supervising you guys. 
I would like to thank the industrial partners of my PhD project: Nutreco (Coen, Jon and Harmen) and Darling Ingredients International (Carine and Fred). Thank you all for your input during the project meetings. Jon, thank you for arranging my broiler trial in Spain. Without your help, the trial would not proceed smoothly as planned.

To my awesome ANU colleagues, it was great to spend the past 4.5 years with you guys. Thank you all for the work-related discussions and coffee-break talks :) I will definitely miss ANU playback shows, Christmas brunches and potluck dinners. I wish you all good luck and great success for your life. To my dear microwaved-lunch group, I really enjoyed your company during lunch breaks. Food always tasted better when you guys were around. Genet, my nice neighbour since beginning. Thank you for all the nice afternoon walks in the summer days.

Soumya, or Sam as how people usually call you here in the Netherlands, we worked in the same research line within the IPOP project. I still remembered our very first conversation and since then I have always known that you would be an excellent colleague. We have been through a lot together (e.g. 20-km daily cycling, fighting with pigs, playing with poop, etc.). It was really nice working with you. Tetske and Sergio, you were always generous in sharing your knowledge and perceptions on proteins with me. For sure I have learnt lot from you guys! I am sure you will shine like stars in your life and career. I hope we will still meet up in the future ;)

I want to thank my paranymphs, 家宜 and Nazri for standing next to me and giving me their supports during my defence. 家宜, 從六年前的一見如故開始, 謝謝你一路上的陪伴。 在這個人生的重要時刻, 能夠有你一起分享真好。Nazri, you have always been a good listener. It is really nice to meet you in ANU.

I started my work in Cargill when I was still finalising my PhD thesis. Many thanks to my colleagues in Cargill for their support during this period. David and Lieske, thank you for all the nice discussions related to nutrient dynamics and offering your help whenever needed.

謝謝所有我在瓦村認識的台灣人們。蓬英姐, 謝謝你七年來逢年過節的照顧。Momo 和佳諭, 轉眼間我們都升格成元老級人物了, 七年後能夠依然和你們一起在荷蘭打拼是我的榮幸。佳 祺和迨霖, 好幸運有你們兩個好鄰居, 在我水深火熱的時候送上溫暖和食物。伊喬和婷婷, 謝謝你們一路上的加油打氣和無數個晚餐約會。 
家人一直都是我最堅強的後盾。親愛的爸媽, 謝謝你們永遠支持我的決定, 讓我無後顧之憂 的走向目標 (雖然你們嘴上總是抱怨我離家太遙遠)。謝謝陳哥哥替我陪伴照顧陳爸爸和陳媽 媽。在論文最後衝刺時刻裡, 讓你們的心情跟著我的情緒一起起伏伏真是抱兼。希望這本博 士論文能讓你們為我感到䣖傲。My genuine thanks to the Rohaan family for their warmth and nice company during holidays and birthdays.

Bram, thank you for being there and sharing all the ups and downs with me over the past years. We have experienced so much together and I believe there is more to explore. As I said before, we age and pair just like wine and steak!

\section{Hsuan/荁}




\section{About the author}

Curriculum vitae

List of publication

Training and supervision plan 


\section{Curriculum vitae}

Hsuan Chen was born in Taipei, Taiwan on November 9, 1987. After graduating from Taipei Private YanPing High School in 2006, Hsuan started her Bachelor study in the department of Animal Science and Technology at National Taiwan University. After obtaining her Bachelor degree in 2010, Hsuan continued her Master study in the Animal Science Department of Wageningen University. During her

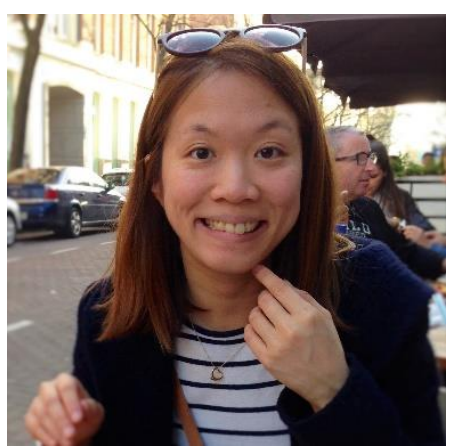
Master study, Hsuan did both her major and minor theses at the Animal Nutritional Group. For the major thesis, Hsuan investigated the effect of processing and enzyme technologies on fibre digestion in broiler chickens. For the minor thesis, Hsuan studied the effect of low dietary phosphorus on the gene expression of phosphorus transporters in the small intestine of pigs. In December 2012, Hsuan started working as a Ph.D. within the IPOP Customised Nutrition project at the Animal Nutritional Group of Wageningen University. During her Ph.D., Hsuan investigated protein digestion kinetics in pigs and poultry. The results of her PhD work are presented in this thesis. In May 2017, Hsuan joined Cagill as a poultry researcher in the Global Innovation Centre, Velddriel, the Netherlands. 


\section{List of publication}

\section{Peer reviewed scientific publications}

Chen, H., P. A. Wierenga, W. H. Hendriks, and A. J. M. Jansman. In vitro protein digestion kinetics of protein sources for pigs. Revision submitted to Animal.

Chen, H., P. A. Wierenga, W. H. Hendriks, and A. J. M. Jansman. Protein sources differ in digestion kinetics in the small intestine of growing pigs and affect postprandial appearance of amino acids in blood. Submitted to Animal.

Chen, H., P. A. Wierenga, W. H. Hendriks, and A. J. M. Jansman. Protein digestion kinetics in the small intestine of broilers differs among protein sources. Submitted to Poultry Science.

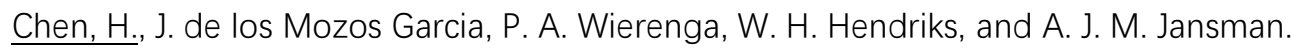
Effect of synchronising the kinetics of protein and starch digestion in the small intestine on the growth performance and carcass characteristics in broilers. To be submitted.

\section{Conference and symposia proceedings}

Chen, $H_{\text {. }}, H$. Gruppen, and A. J. M. Jansman. Dietary protein degradation: evaluating protein hydrolysis kinetics in the stomach and small intestine of pigs using a two-step in vitro method. Proceedings of the 3rd International Conference on Food Digestion, 11-13 March, 2014, Wageningen, the Netherland

Chen, H., P. A. Wierenga, H. Gruppen, and A. J. M. Jansman. Evaluation of the kinetics of protein hydrolysis in the stomach and small intestine of pigs using a two-step in vitro method. Proceedings of the $13^{\text {th }}$ Digestive Physiology of Pigs, 19-21 May, 2015, Kliczków, Poland.

Chen, $H_{\text {., }}$ H. Gruppen, and A. J. M. Jansman. Evaluating protein digestion kinetics in the stomach and small intestine of pigs using a two-step in vitro method. Proceedings of the WIAS Science Day, 5 February, 2015, Wageningen, the Netherlands

Chen, H., P. A. Wierenga, and A. J. M. Jansman. Protein digestion kinetics of different protein sources in broilers. Proceedings of the $5^{\text {th }}$ International Symposium on Energy and Protein Metabolism and Nutrition, 12-15 September, 2016, Krakow, Poland. 
Chen, H., P. A. Wierenga, and A. J. M. Jansman. Protein digestion kinetics of different protein sources in pigs. Proceedings of the $5^{\text {th }}$ International Symposium on Energy and Protein Metabolism and Nutrition, 12-15 September, 2016, Krakow, Poland.

Chen, H., P. A. Wierenga, and A. J. M. Jansman. Protein digestion kinetics of different protein sources in pigs. Proceedings of the $1^{\text {st }}$ Protein for Life Conference, 23-26 October, 2016, Ede, the Netherlands, 


\section{Training and supervision plan ${ }^{1}$}

The Basic Package (3 ECTS ${ }^{2}$ )

WIAS Introduction Course

2013

Course on philosophy of science and/or ethics

\section{Scientific Exposure (11 ECTS)}

International conferences

$3^{\text {rd }}$ International Conference on Food Digestion, Wageningen, the

Netherland

$13^{\text {th }}$ Digestive Physiology of Pigs, Kliczkow, Poland

2015

$5^{\text {th }}$ EAAP International Symposium on Energy and Protein

Metabolism and Nutrition, Krakow, Poland

$1^{\text {st }}$ Protein for Life Conference, Ede, the Netherlands

2016

Seminars and workshops

WIAS Science Day

2013

Nutrient Requirements and Animal Health

2015

$41^{\text {th }}$ Animal Nutrition Research Forum

\section{Presentations}

'Dietary protein degradation: evaluating protein hydrolysis kinetics in the stomach and small intestine of pigs using a two-step in vitro method', $3^{\text {rd }}$ International Conference on Food Digestion, Wageningen, the Netherland, Poster presentation

'Evaluation of the kinetics of protein hydrolysis in the stomach and 2015 small intestine of pigs using a two-step in vitro method', $13^{\text {th }}$ Digestive Physiology of Pigs, Kliczkow, Poland, Poster presentation

'Fast or slow: speed of protein digestion makes a difference', Quality of Protein in Animal Diets, Wageningen, the Netherland, Oral presentation

'Protein digestion kinetics of different protein sources in broilers', $5^{\text {th }}$ 2016 EAAP International Symposium on Energy and Protein Metabolism and Nutrition, Krakow, Poland, Oral presentation.

'Protein digestion kinetics of different protein sources in pigs', $5^{\text {th }}$ EAAP International Symposium on Energy and Protein Metabolism and Nutrition, Krakow, Poland, Poster presentation. 
'Protein digestion kinetics of different protein sources in pigs', $1^{\text {st }}$

Protein for Life Conference, Ede, the Netherlands, Oral presentation.

\section{In-Depth Studies (7 ECTS)}

Disciplinary and interdisciplinary courses

Industrial Food Proteins, Graduate School VLAG, Wageningen, the

Netherlands

Food Digestion and Human Nutrition, INFOGEST Cost Action,

Budapest, Hungary

Quality of Protein in Animal Diets, Wageningen Academy,

Advances in Feed Evaluation Science, Wageningen Academy,

Wageningen, the Netherlands

Design of Experiment

2013

Statistics for life sciences

Statutory Courses (3 ECTS)

Use of Laboratory Animals (mandatory when working with animals)

Professional Skills Support Courses (3 ECTS)

Project and Time Management

Course Supervising MSc thesis work

Course Techniques for Scientific Writing

Research Skills Training (6 ECTS)

Preparing own PhD research proposal

Didactic Skills Training (8 ECTS)

Supervising MSc major thesis (4x)

Education and training total

41 ECTS

${ }^{1}$ Completed in the fulfilment of the requirements for the education certificate of the Graduate School Wageningen Institute of Animal Sciences (WIAS).

${ }^{2}$ One ECTS equals a study load of 28 hours. 


\section{Colophon}

The research described in this thesis is part of the IPOP Customized Nutrition project of Wageningen University \& Research and was financially supported by Wageningen University \& Research, the Dutch Ministry of Economic Affairs, Nutreco NV and Darling Ingredients International.

Cover Design and lay-out: Chia-Yi Liu, Ling-Kwang Low and Hsuan Chen

Printed by Proefschriftmaken 